\title{
AVALIAÇÃO DO CICLO DE VIDA ENERGÉTICO DO PROCESSO DE FABRICAÇÃO DE \\ EMBALAGENS METÁLICAS: ESTUDO DE CASO PARA LATAS DE BEBIDAS
}

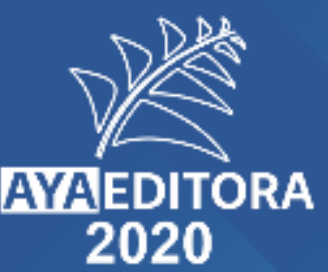




\section{AVALIAÇÃO DO CICLO DE VIDA ENERGÉTICO DO PROCESSO DE FABRICAÇÃO DE EMBALAGENS METÁLICAS: ESTUḐO DE CASO PARA LATAS DE BEBIDAS}




\section{ENGENHARIAS}

\section{AURÉLIO KOVALESKI \\ APARECIDO DOS REIS COUTINHO}

\begin{tabular}{r|l} 
Editor Chefe: & Prof $^{\circ}$ Dr. Adriano Mesquita Soares \\
Bibliotecária: & Bruna Cristina Bonini - CRB 9/1347 \\
Capa: & Designed by Freepik \\
Diagramação: & Ana Lucia Ribeiro Soares \\
Revisão: & Os Autores
\end{tabular}

\section{Conselho Editorial}

Prof. ${ }^{\text {a }}$ Dr. ${ }^{\text {a }}$ Andreia Antunes da Luz - Faculdade Sagrada Família

Prof. ${ }^{\text {a D }}$ Dr. ${ }^{\text {a }}$ Daiane Maria De Genaro Chiroli - Universidade Tecnológica Federal do Paraná

Prof. ${ }^{\circ}$ Dr. Gilberto Zammar - Universidade Tecnológica Federal do Paraná

Prof. ${ }^{\text {a }}$ Ma. Jaqueline Fonseca Rodrigues - Faculdade Sagrada Família

Prof. ${ }^{\circ}$ Dr. João Luiz Kovaleski - Universidade Tecnológica Federal do Paraná

Prof. ${ }^{\circ}$ Me. Jorge Soistak - Faculdade Sagrada Família

Prof. ${ }^{\circ}$ Me. Luiz Henrique Domingues - Universidade Norte do Paraná

Prof. ${ }^{\circ}$ Me. Myller Augusto Santos Gomes - Universidade Estadual do Centro-Oeste

Prof. ${ }^{\text {a }}$ Dr. ${ }^{a}$ Pauline Balabuch - Faculdade Sagrada Família

Prof. ${ }^{\circ}$ Me. Pedro Fauth Manhães Miranda - Centro Universitário Santa Amélia

Prof. - Dr. ${ }^{\text {a }}$ Regina Negri Pagani - Universidade Tecnológica Federal do Paraná

Prof. ${ }^{\circ}$ Me. Rudy de Barros Ahrens - Faculdade Sagrada Família

Prof. - Ma. Silvia Aparecida Medeiros Rodrigues - Faculdade Sagrada Família

Prof. ${ }^{\text {a }}$ Dr. ${ }^{\text {a }}$ Silvia Gaia - Universidade Tecnológica Federal do Paraná

Prof. - Dr. - Sueli de Fátima de Oliveira Miranda Santos - Universidade Tecnológica Federal do Paraná Prof. ${ }^{\underline{a}}$ Dr. ${ }^{\text {a }}$ Thaisa Rodrigues - Instituto Federal de Santa Catarina 


\section{ENGENHARIAS}

\section{AVALIAÇÃO DO CICLO DE VIDA ENERGÉTICO DO PROCESSO DE}

FABRICAÇÃO DE EMBALAGENS METÁLICAS: ESTUDO DE CASO PARA LATAS DE BEBIDAS

$\begin{array}{rll}\text { Editor Chefe: } & \text { Prof }^{\circ} \text { Dr. Adriano Mesquita Soares } \\ \text { Bibliotecária: } & \text { Bruna Cristina Bonini - CRB 9/1347 } \\ \text { Capa: } & \begin{array}{l}\text { Designed by Freepik } \\ \text { Diagramação: }\end{array} & \begin{array}{l}\text { Ana Lucia Ribeiro Soares } \\ \text { Revisão: }\end{array} \\ & \text { Os Autores }\end{array}$

Kovaleski, Aurélio

K884 Avaliação do ciclo energético do processo de fabricação de embalagens metálicas: estudo de caso para latas de bebidas /. Aurélio Kovaleski; Aparecido dos Reis Coutinho. -- Ponta Grossa: Aya, 2020. 83 p.. -- ISBN: 978-65-88580-01-1

\section{Formato: PDF}

Requisitos de sistema: Adobe Acrobat Reader.

Modo de acesso: World Wide Web.

DOI: 10.47573/aya.88580.1.1

1. Latas de bebidas. 2. Embalagens metálicas. 3. Avaliação do ciclo de vida (ACV). 4. Avaliação do ciclo de vida energético (ACVE). 5. Eficiência energética. I. Coutinho, Aparecido dos Reis. II. Título.

CDD: 620

\section{AYA Editora}

+55 (42) 3086-3131

contato@ayaeditora.com.br

https://ayaeditora.com.br

Rua: João Rabello Coutinho, 557

Ponta Grossa - Paraná - Brasil

84.071-150 


\section{SUMÁRIO}

INTRODUÇÃO

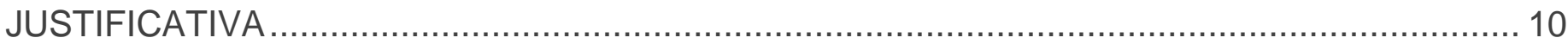

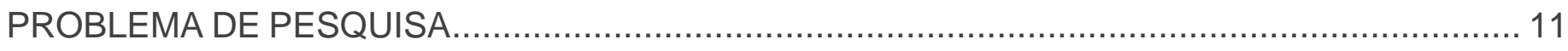

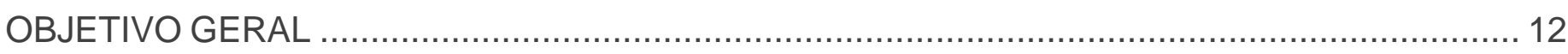

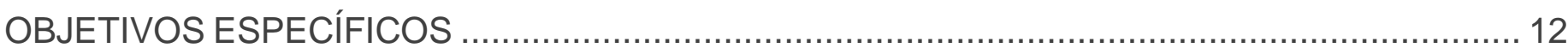

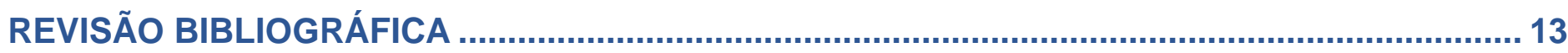

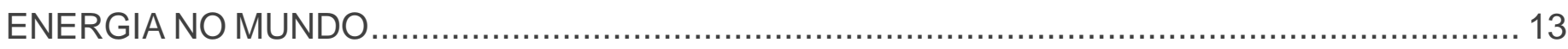

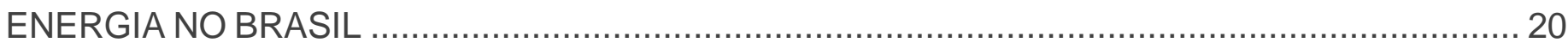

EFICIÊNCIA ENERGÉTICA E GESTÃO DE ENERGIA NO SETOR INDUSTRIAL ......................... 27

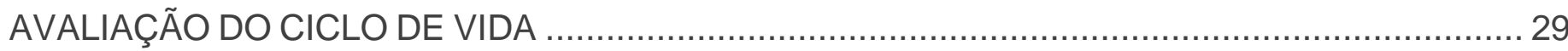

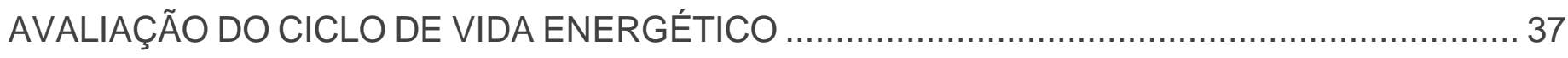

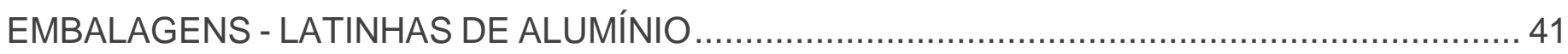

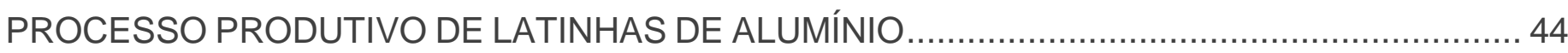

METODOLOGIA

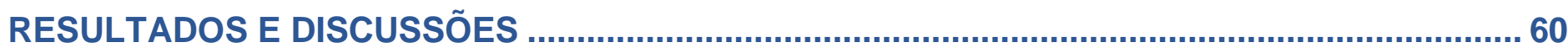

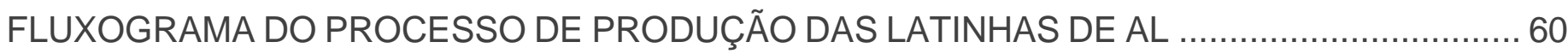

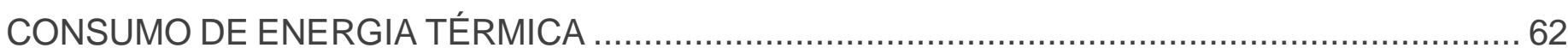

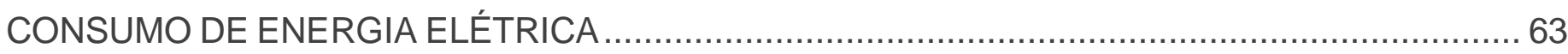

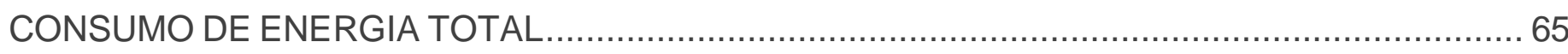

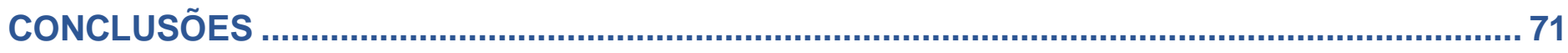

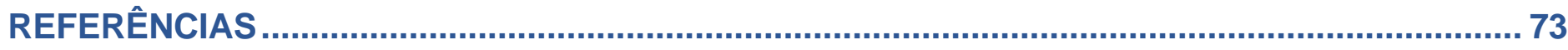




\section{RESUMO}

\section{Como citar:}

KOVALESKI, Aurélio; COUTINHO, Aparecido dos Reis. Avaliação do ciclo de vida energético do processo de fabricação de embalagens metálicas: estudo de caso para latas de bebidas. Ponta Grossa: AYA Editora, 2020.

As consequências ambientais do aumento do consumo de energia trazem mudanças climáticas e aquecimento global. O uso racional da energia torna-se uma palavra-chave para o desenvolvimento sustentável mundial. O setor industrial configura-se como o que mais consome energia no mundo e no Brasil, onde a indústria alimentícia encontra-se como o segmento com o maior índice de consumo de energia. A Avaliação do Ciclo de Vida (ACV) é passo fundamental para um gerenciamento sustentável. Apesar da popularidade da ACV no campo de embalagens metálicas para bebidas, verifica-se a ausência de estudos com relação ao sistema produtivo destas. Enquanto a ACV avalia os impactos de uma forma geral, uma análise derivativa, chamada de Avaliação do Ciclo de Vida Energético (ACVE) concentra-se na energia como a única medida do impacto ambiental. A ACVE vem sendo empregada nas últimas décadas no setor industrial devido aos esforços direcionados ao aumento da eficiência energética. $O$ presente trabalho tem por objetivo empregar a ACVE para quantificar o consumo energético de uma planta de fabricação de embalagens metálicas para bebidas, por meio de abordagem metodológica de estudo de caso exploratório, visando proporcionar maior familiaridade com o problema abordado. Para tanto, foi realizada a coleta dos dados em Industria produtora de latas metálicas de alumínio para bebidas. O trabalho apresentou uma análise em relação a todas as etapas do processo produtivo investigado a fim de demonstrar seus consumos de energia térmica e elétrica. Verificou-se que o balanço energético no processo de produção de latas de alumínio apresenta como fonte predominante de energia a eletricidade (57,7\%). No entanto, apesar da energia térmica ser aplicada em somente três etapas ao longo do processo, possui uma participação expressiva (42,3\%). O consumo total de energia no processo foi de $105.021 \mathrm{~kJ}$ por 1000 embalagens produzidas.

Palavras-chave: Latas de bebidas. Embalagens metálicas. Avaliação do Ciclo de Vida (ACV). Avaliação do Ciclo de Vida Energético (ACVE). Eficiência energética. 


\section{ABSTRACT}

The environmental consequences of increased energy consumption bring climate change and global warming. The rational use of energy becomes a key word for global sustainable development. The industrial sector is the most energy-consuming sector in the world and in Brazil, where the food industry is the segment with the highest energy consumption index. The Life Cycle Assessment (LCA) is a key step towards sustainable management. Despite the popularity of ACV in the field of metallic beverage packaging, there is a lack of studies regarding the production system of these. While LCA evaluates impacts in a general way, a derivative analysis, called Energy Life Cycle Assessment (LCEA), focuses on energy as the only measure of environmental impact. ACVE has been used in the last decades in the industrial sector due to efforts directed at increasing energy efficiency. The objective of this work is to use ACVE to quantify the energy consumption of a metallic beverage packaging manufacturing plant by means of an exploratory case study method, aiming to provide greater familiarity with the problem addressed. For this purpose, the data was collected in an industry of aluminum packaging for beverages. The work presented an analysis in relation to all stages of the productive process investigated in order to demonstrate its consumption of thermal and electric energy. It was verified that the energy balance in the process of production of aluminum cans presents as predominant source of energy the electricity $(57.7 \%)$. However, although thermal energy is applied in only three steps throughout the process, it has an expressive participation (42.3\%). The total energy consumption in the process was $105,021 \mathrm{~kJ}$ per 1000 produced packages.

Keywords: Beverage cans. Metal containers. Life Cycle Assessment (LCA). Life Cycle Energy Assessment (LCEA). Energy efficiency. 


\section{INTRODUÇÃO}

A onda de globalização não só integrou os países, social, política e economicamente, mas também intensificou a crescente concorrência entre os países desenvolvidos e em desenvolvimento do século XXI. A tendência de aumento da concorrência entre países desenvolvidos e em desenvolvimento é entendida por meio de um crescimento econômico mais elevado, acompanhado pelo uso massivo de energia. As consequências ambientais do aumento do consumo de energia trazem mudanças climáticas e aquecimento global, que são prejudiciais ao meio ambiente e ao ser humano. Para reduzir o aquecimento global, governos de países com alta emissão de poluentes estão planejando reduzir seu consumo de energia aumentando o desenvolvimento da inovação energética (SHAHBAZ et al., 2018).

A globalização das economias mundiais se posiciona como um grande desafio para as sociedades, mas também trazem a oportunidade de colocar a sustentabilidade em escala global, pois os impactos ambientais não respeitam fronteiras. A globalização também enfatiza a necessidade de uma perspectiva de ciclo de vida, a qual é inerente a sustentabilidade (HAUSCHILD et al., 2005).

Ano após ano, empresas, indústrias e organizações governamentais têm estado sob enormes pressões econômicas e ambientais. Ser econômico e competitivo no mercado global e atender aos crescentes padrões ambientais para reduzir a poluição do ar e da água, têm sido os principais fatores determinantes na maioria das recentes decisões de investimento em custo operacional e custo de capital para todas as organizações. O mapeamento de energia tem sido uma ferramenta importante para ajudar as organizações a atingir esses objetivos críticos para sua sobrevivência a curto prazo e sucesso a longo prazo (DOTY e TURNER, 2009).

Devido ao aquecimento global, a questão energética vem tendo posição de destaque na agenda ambiental. Isso se deve ao fato de que a atual matriz energética mundial depende ainda de cerca de $80 \%$ de combustíveis fósseis, grandes geradores de gases de efeito estufa (GEE). A importância da busca de maior eficiência energética e da transição para o uso de recursos energéticos renováveis tem sido ressaltada em qualquer agenda com foco na avaliação sobre desenvolvimento sustentável (REIS, 2011).

O uso racional da energia torna-se uma palavra-chave para o desenvolvimento sustentável (DS) mundial, tanto nos países desenvolvidos como nos países em desenvolvimento (MARECHAL et 
al., 2005). De acordo com Shahbaz et al. (2018) além da mão de obra e do capital, o consumo de energia é indispensável para o desenvolvimento econômico dos países.

A energia configura-se como elemento essencial à vida humana. (GOLDEMBERG e LUCON, 2007). Isso se deve ao fato de que a energia proporciona oportunidades e alternativas tanto para a comunidade como para o indivíduo. Para o desenvolvimento da economia de uma região e o acesso a serviços essenciais que proporcionam aumento da qualidade da vida, como educação, saneamento e saúde pessoal, é necessária uma fonte de energia confiável (REIS, 2011).

O consumo de energia mundial segue em tendência de crescimento nos últimos anos. Dentre os setores consumidores, destaca-se o setor industrial com o valor mais elevado de consumo (IEA, 2018). Por sua vez, o Brasil também segue em crescimento no seu consumo de energia, sendo domesticamente também o setor industrial como maior consumidor. Visualiza-se porém, que o setor industrial brasileiro vem diminuindo sua participação ano após ano, devido aos esforços concentrados em eficiência energética no setor e as novas tecnologias empregadas nos processos industriais (EPE, 2018).

Com o crescimento da população mundial, verifica-se um aumento do consumo de diferentes tipos de produtos alimentícios e suas respectivas embalagens. Dessa forma, verifica-se um aumento mundial expressivo no consumo de embalagens (PASQUALINO et al., 2011). As embalagens vêm se desenvolvendo ao longo das décadas e anos, e seu uso intenso vem gerando aumentos no consumo de recursos naturais. Esse aumento no consumo se deve principalmente ao fato da facilidade de comprar produtos prontos para o consumo (BARROS et al., 2018)

A crescente preocupação com a produção e consumo sustentável de embalagens levou a diferentes atividades de pesquisa sobre seus processos produtivos industriais. Nesse contexto, a Avaliação do Ciclo de Vida (ACV), tem sido aplicada com predominância devido a sua abrangência (ROY et al., 2009).

Cortez (2011) destaca que existem ganhos expressivos em relação a integração dos aspectos ambientais no setor de produção de embalagens: otimização do uso de matérias-primas, energia e água; processos fabris mais eficientes; redução da geração de resíduos industriais; estímulo à inovação e criatividade; incremento do conhecimento sobre a embalagem; melhoria da imagem da empresa e da marca; entre outros.

O mercado brasileiro atual de embalagens para bebidas em alumínio encontra-se em plena expansão. Em 1998, a capacidade de produção brasileira encontrava-se em 11,5 bilhões de unidades, enquanto somente $62 \%$ dessa capacidade era utilizada. Em 2017, a capacidade produtiva encontra- 
se em 28 bilhões de unidades, com utilização de $91 \%$ da capacidade atual, perfazendo uma produção anual de 25,4 bilhões de unidades (ABRALATAS, 2018).

\section{JUSTIFICATIVA}

Empresas e corporações do mundo todo vêm trabalhando em obter processos produtivos mais limpos, em que se emprega menor quantidade de matérias primas e se utilizam menos energia em sua produção. Poucas empresas tratam a energia como um indicador chave, embora a mesma venha a representar uma grande proporção dos custos da operação. Além do fator custo, parte crescente da sociedade está com a consciência voltada para o tema, implicando com que o mesmo aumente em importância em um futuro próximo (RUDBERG et al., 2013).

Independente se na etapa de produção ou consumo, todos os produtos, bens ou serviços causam impactos ambientais em todas as suas etapas: aquisição de matéria prima, fabricação, distribuição, uso e descarte final. Esses impactos podem vir a ser mais ou menos significativos, podendo ser de curta ou longa duração e ainda, ser locais, regionais ou globais (CORTEZ, 2011).

Com o rápido desenvolvimento da economia global, as exigências aumentaram notavelmente sobre o consumo energético, especialmente em países emergentes. A percepção de que os recursos de combustíveis fósseis necessários para a geração de energia estão se tornando escassos e de que as mudanças climáticas estão relacionadas às emissões de carbono na atmosfera aumentaram o interesse da sociedade nas questões relacionadas à economia de energia e proteção ambiental. A principal estratégia para reduzir a dependência de recursos fósseis baseia-se na redução da demanda de energia através da eficiência energética nas esferas industriais e domésticas (BANOS et al., 2011).

A política ambiental mundial tornou-se mais restritiva nas últimas décadas, apesar de ainda existirem problemas tecnológicos, de mercado e ambientais no horizonte e pouco consenso científico sobre a metodologia apropriada para comparar o desempenho ambiental de produtos e alternativas de processo (ALMEIDA et al., 2010).

O setor industrial configura-se como o setor que mais consome energia no mundo (IEA, 2018). No Brasil o setor industrial ocupa o lugar de maior consumidor e a indústria de alimentos e bebidas encontra-se como o segmento com o maior índice de consumo de energia, em que o consumo energético nos processos produtivos deste ramo passa a ser estratégico (EPE, 2018).

As embalagens metálicas para bebidas vêm se tornando cada vez mais populares no mercado brasileiro, ostentando crescimento de $80 \%$ na produção brasileira nos últimos 10 anos. Devido a essa 
demanda, diversas novas fabricas foram instaladas recentemente no país, assim como antigas fabricas foram expandidas visando aumentar capacidade de produção (ABRALATAS, 2018).

A ACV é considerada uma técnica adequada e assertiva na avaliação da produção de embalagens de alimentos e opções de descarte destas embalagens. (AMIENYO et al., 2013). Consequentemente, a área de embalagens para bebidas apresenta-se como um dos principais focos da aplicação dos estudos de ACV (HUANG e MA, 2004). Estes trabalhos possuem, diversas aplicações, sendo as mais comuns a comparação dos impactos ambientais entre embalagens de materiais diferentes (SIMON et al., 2016; SALEH, 2016; PASQUALINO et al., 2011), reciclagem das embalagens (PARASKEVAS et al., 2015; VAN DER HARST et al., 2015; STOTZ et al., 2017) e ACV do ciclo completo da produção das embalagens (BUNGĂRDEAN et al., 2013; GATTI et al., 2008; NIERO e OLSEN, 2016). No entanto, verifica-se a ausência de trabalhos na literatura focados especificamente no processo produtivo destas embalagens.

A ACVE, derivativa da ACV, que compartilha as mesmas etapas e modo de aplicação, concentra-se na energia como a única medida de impactos ambientais (HUBERMAN e PEARLMUTTER, 2008). A ferramenta foi concebida para apresentar uma análise mais detalhada da energia para produtos e serviços em que impactos ambientais sejam gerados pelo consumo de energia (MENZIES et al., 2007). Apesar de comum na construção civil, a ACVE ainda é pouco utilizada no setor industrial e não possui aplicações no setor de embalagens para bebidas, setor no qual a ACV se destaca na literatura atual.

Visualizando o crescente aumento na produção de embalagens metálicas para bebidas e a lacuna de pesquisa referente a ausência de trabalhos de $A C V$ aprofundados no processo produtivo das latinhas e ausência de trabalhos de ACVE no setor de embalagens para bebidas, justifica-se o estudo em questão, o qual objetiva empregar a ACVE para quantificar o consumo energético de uma planta de fabricação de embalagens metálicas para bebidas.

\section{PROBLEMA DE PESQUISA}

Considerando o contexto apresentado e a escassez de trabalhos relativos a análise energética no processo produtivo de embalagens metálicas para bebidas, as principais questões de pesquisa que norteiam o trabalho são:

1) Como a ACVE pode ser utilizada no processo produtivo de embalagens metálicas para bebidas? 
2) Qual o consumo de energia elétrica e térmica por etapa do processo de produção embalagens metálicas para bebidas?

3) Quais áreas devem ser avaliadas visando elevar a eficiência energética do processo produtivo? Quais opções cada área possui?

\section{OBJETIVO GERAL}

O presente trabalho tem por objetivo geral empregar a ACVE para quantificar o consumo energético de uma planta de fabricação de embalagens metálicas para bebidas.

\section{OBJETIVOS ESPECÍFICOS}

a) Elaborar o fluxograma do processo de produção das latas de alumínio;

b) Identificar e quantificar os consumos de eletricidade e de gás natural em cada etapa do processo de produção;

c) Elaborar o balanço de energia do processo produtivo de embalagens metálicas;

d) Utilizar os conceitos da ACVE para elaborar um fluxograma energético do processo de fabricação das embalagens metálicas. 


\section{REVISÃO BIBLIOGRÁFICA}

\section{ENERGIA NO MUNDO}

As fontes primárias utilizadas para a geração de energia podem ser definidas como renováveis ou não renováveis. As fontes não renováveis são aquelas em que existe a possibilidade de esgotamento, que ocorre em função da velocidade em que a mesma é consumida. Encontram-se na categoria de fontes não renováveis todos os derivados de petróleo, combustíveis radioativos (uranio, tório, plutônio, etc.), a energia geotérmica e o gás natural (GN). A geração de energia elétrica a partir dessas fontes e feita geralmente pela transformação da fonte primária em energia térmica por meio de combustão, fissão ou processos geotérmicos. A geração de energia a partir deste meio descrito é conhecida como geração termelétrica (REIS, 2011).

A Figura 1 mostra o consumo de energia no mundo a partir do relatório Key World Energy Statistics da International Energy Agency (IEA, 2018), em que para finalidade de padronização, 0 relatório teve a unidade convertida de tep para TWh. A análise do conteúdo busca avaliar o consumo de energia no mundo, para o consumo geral e o consumo industrial.

Figura 1 - Consumo mundial de energia 2000-2016

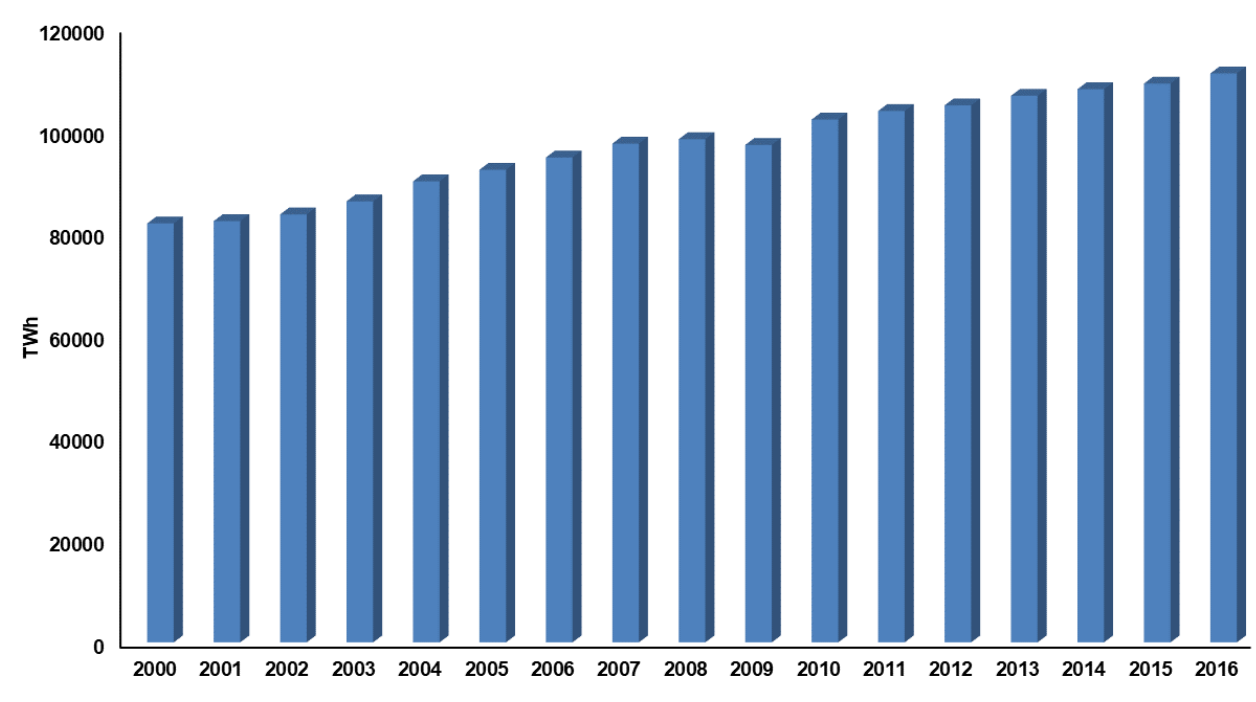

Fonte: IEA (2018)

Conforme a Figura 1 verifica se que o consumo de energia no mundo aumentou 25\% no período compreendido entre os anos 2000-2017, configurando um crescimento médio de 1,66\% no consumo de energia mundial por ano. No entanto, o crescimento médio no consumo dos últimos cinco 
anos foi da ordem de $1,5 \%$, demonstrando uma retração na média do aumento do consumo de energia.

Por outro lado, em estudo feito pela IEA (2017) estima-se que o consumo mundial de energia deve aumentar em 13,2\% de 2015 para 2030; e em 21,8\% de 2015 a 2040. Estima-se que a maior parte do aumento na demanda por energia venha de países não membros da OCDE (Organização para Cooperação e Desenvolvimento Econômico) onde o forte crescimento econômico, o aumento do acesso à energia comercializada e o crescimento rápido das populações levam à crescente demanda por energia. Além disso, prevê-se que o consumo de energia nos países não membros da OCDE aumente de $41 \%$ entre 2015 e 2040, em contraste com um aumento de $9 \%$ nos países membros da OCDE.

Ainda segundo previsões da IEA (2017) a geração líquida de eletricidade nos países não membros da OCDE aumentará em média 1,9\% ao ano, entre 2015-2040, em comparação com 1,0\% ao ano nos países da OCDE. As energias provenientes de fontes renováveis (incluindo a energia hidráulica) são as fontes que mais crescerão no período de 2015-2040, aumentando em média 2,8\% ao ano, na medida em que ocorrer melhorias tecnológicas e incentivos governamentais em muitos países. A participação da energia hidrelétrica na energia renovável reduzirá de $71 \%$ em 2015 para $53 \%$ em 2040, tendo se em vista que a disponibilidade de recursos nos países da OCDE e as preocupações ambientais em muitos países limitam o número de novos projetos hidrelétricos de médio e grande porte.

Em contrapartida, a geração a partir de fontes renováveis não-hidrelétricas aumentará em média 4,9\% ao ano, entre 2015-2040. Entre as fontes de energia renováveis não-hidrelétricas, a eólica e a solar aumentarão ao longo do período de 2015-2040, atingindo 2,5 e 1,4 trilhão de quilowatts, respectivamente, à medida que essas tecnologias se tornam mais competitivas em termos de custos ao longo do tempo. 
Figura 2 - Consumo de energia não renovável mundial

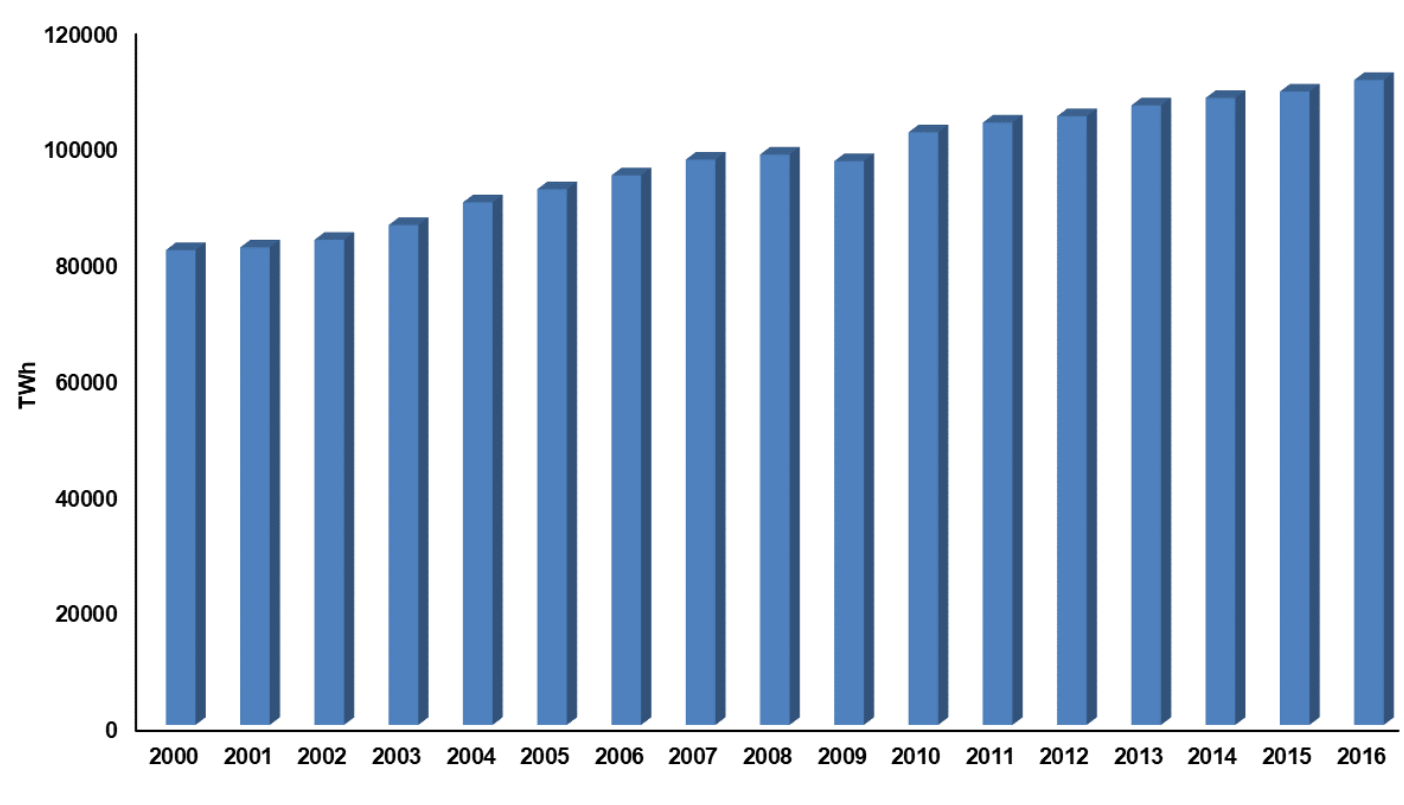

Fonte: IEA (2018)

A Figura 2 mostra a predominância das energias não renováveis na matriz energética mundial, em que entre 2000-2016, ocorreu um ligeiro aumento das energias não renováveis na matriz. Enquanto em 2000 o mundo exibia o indicador de 85\% para o consumo de energias não renováveis, em 2016 o indicador subiu para aproximadamente $88 \%$.

O ano de 2016 teve diversos pontos positivos voltados ao cenário das energias renováveis, como avanços constantes em tecnologias, melhorias contínuas em eficiência energética, elevação no uso de tecnologias de redes inteligentes, avanços significativos em hardware e software para apoiar a integração de energias renováveis, assim como avanços no desenvolvimento e comercialização de armazenamento de energia (REN21, 2016). A Figura 3 monstras o consumo de energias não renováveis no mundo e sua participação na matriz energética mundial, entre os anos 2000-2016. 
Figura 3 - Consumo de energia renovável mundial

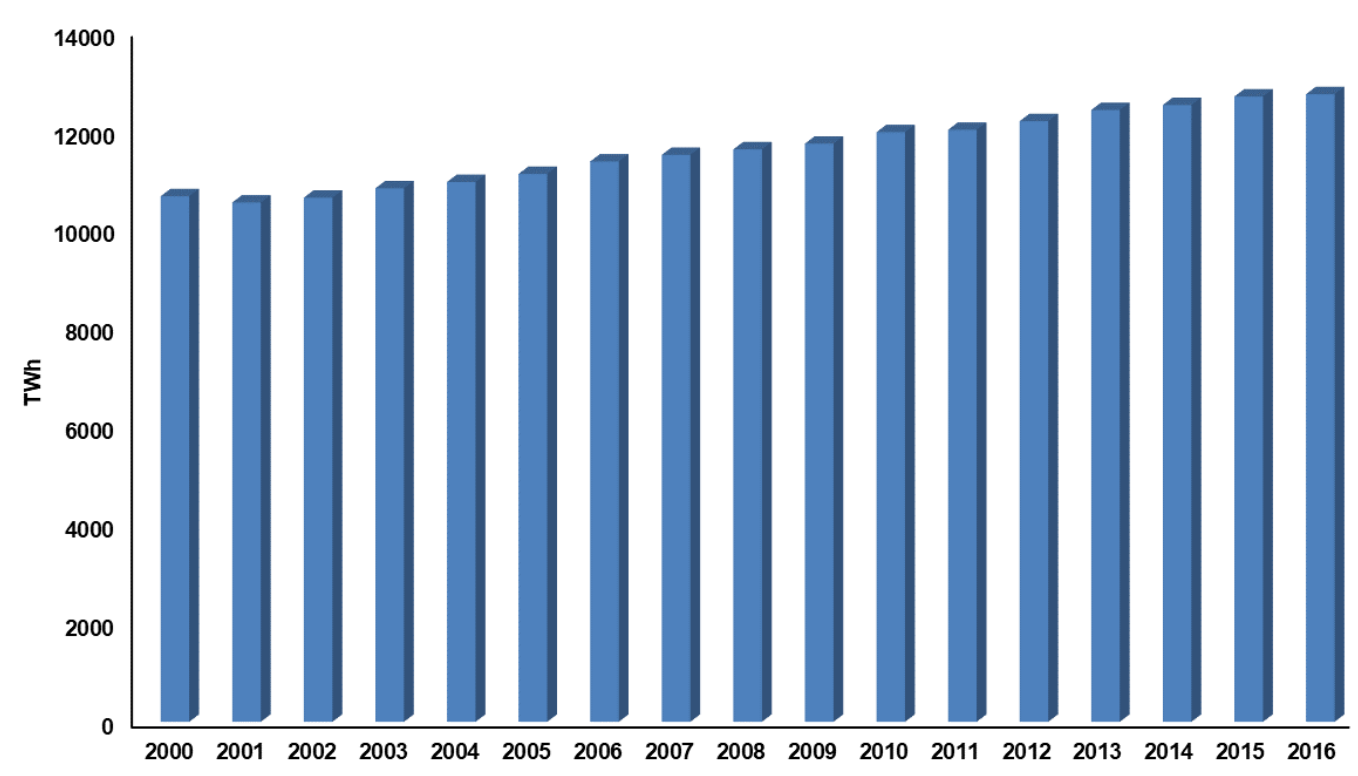

Fonte: IEA (2017)

Verifica-se que as energias renováveis no período de 2000-2016 tiveram crescimento de $15,95 \%$ no consumo absoluto. No entanto, a participação das mesmas na matriz energética mundial teve leve declínio, de 14,98\% em 2000 para 13,15\% em 2016.

O crescimento rápido das energias renováveis, particularmente no setor elétrico, é impulsionado por vários fatores. A melhoria na competividade dos custos das tecnologias renováveis, as iniciativas de políticas públicas específicas, o melhor acesso a financiamentos, as preocupações ambientais e de segurança energética, demanda crescente de energia nas economias em desenvolvimento e emergentes e a necessidade de acesso à energia moderna, configuram-se como principais fatores para o avanço das energias renováveis. Desta forma, novos mercados para energia renovável estão surgindo em todas as regiões, perfazendo com que a mesma esteja hoje estabelecida em todo o mundo como fonte importante de energia (REN21, 2016).

De acordo com projeções estabelecidas pelas IEA (2017) o uso mundial de energia no setor industrial aumentará 18\% de 2015 a 2040. Durante todo esse período, o uso de energia deve superar qualquer setor de uso final, respondendo por mais de 50\% durante todo o período de projeção. O uso de motores e iluminação mais eficientes, avanços em termos de automação, a implementação de novas soluções para processamento e gerenciamento de processos são mudanças tecnológicas no setor industrial que podem gerar impacto significativo na conservação de energia.

Embora o setor industrial continue sendo o maior setor consumidor de energia mundial ao longo do período da projeção, a demanda de energia em outros setores deverá crescer mais 
rapidamente do que no setor industrial. O uso mundial de energia no setor industrial aumentará em 0,7\%/ano de 2015 a 2040, em comparação com um aumento de 1,0\%/ano para transportes e $1,1 \%$ /ano para edificações. A maior parte (89\%) do aumento do uso de energia no setor industrial deverá ocorrer em nações não pertencentes à OCDE, caso do Brasil. O uso de energia no setor industrial em países não membros da OCDE deverá crescer 0,8\%/ano, em comparação com um aumento de $0,2 \%$ /ano nos países pertencentes a OCDE. Dessa forma, a quota industrial do consumo mundial de energia diminui de 55\% em 2015 para 52\% em 2040, em grande parte devido ao crescimento mais rápido do setor de transportes (IEA, 2017).

Por outro lado, a Figura 4 mostra a evolução do consumo de energia do setor industrial.

Figura 4 - Consumo mundial de energia na indústria em TWh

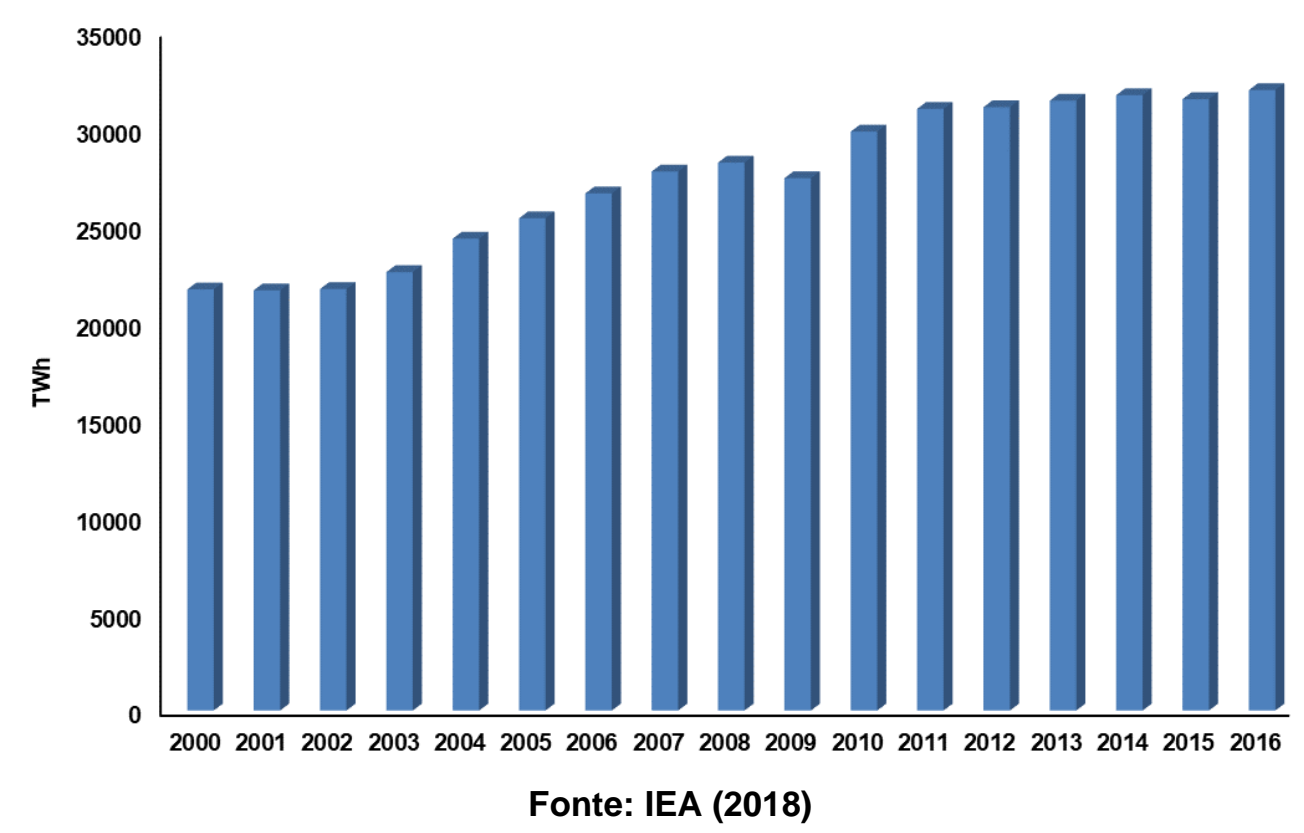

Conforme a Figura 4, verifica-se o acentuado crescimento no consumo de energia na indústria no período de 2000-2016. O crescimento absoluto foi na ordem de $32 \%$. A Figura 4 ainda demonstra que crises mundiais, como a ocorrida em 2009, afetaram o consumo de energia industrial no mundo. No entanto, verifica-se que após a crise, o consumo teve uma grande retomada, acumulando crescimento de $11,5 \%$ no período entre $2009-2011$.

Nos últimos cinco anos, de 2012 a 2016, ocorreu uma estagnação no consumo de energia na indústria no mundo todo. De acordo com o REN21 (2016) a intensidade energética global da indústria vem em declínio nos últimos anos. Isso se deve, em parte, aos altos investimentos em eficiência energética, sendo que somente em 2013, US\$ 130 bilhões foram investidos no segmento industrial. Este fato pode também ser visualizado pela Figura 5, referente a participação do consumo de energia da indústria com relação ao consumo de energia mundial. 
Figura 5 - Participação total da indústria no consumo de energia mundial

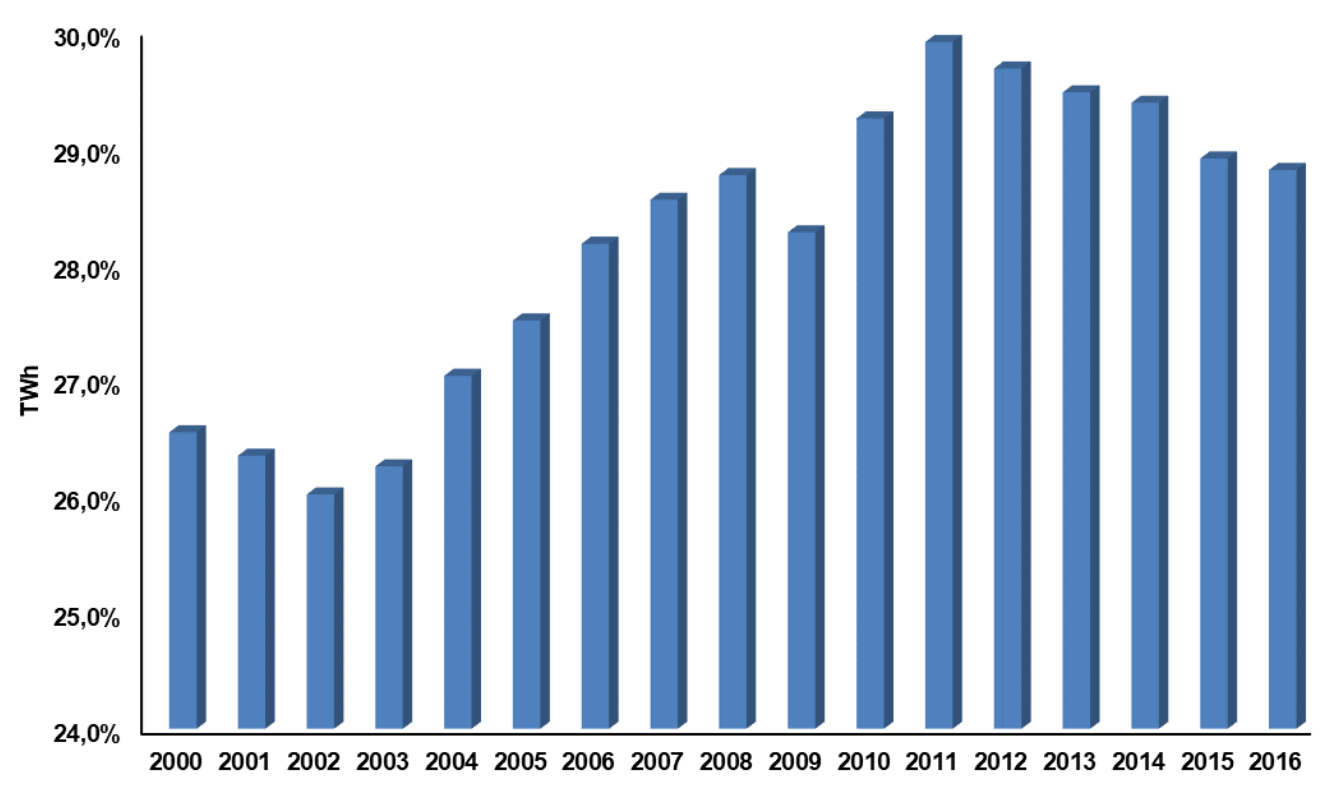

Fonte: IEA (2018)

A Figura 5 mostra a ascensão da participação da indústria no consumo de energia até meados de 2011, quando o ápice foi atingido, alcançando em torno de $30 \%$ de participação. A partir dessa data, o consumo de energia decresce até 2016.

Além disso, a Figura 6 mostra o crescimento na participação das energias não renováveis na matriz de consumo energético industrial. Apesar do valor percentual ter tido crescimento reduzido, de 91\% para 93\%, em valores absolutos o crescimento representa uma expansão de quase $47 \%$ das energias não renováveis no uso industrial.

Figura 6 - Consumo mundial de energia não renovável na indústria em TWh

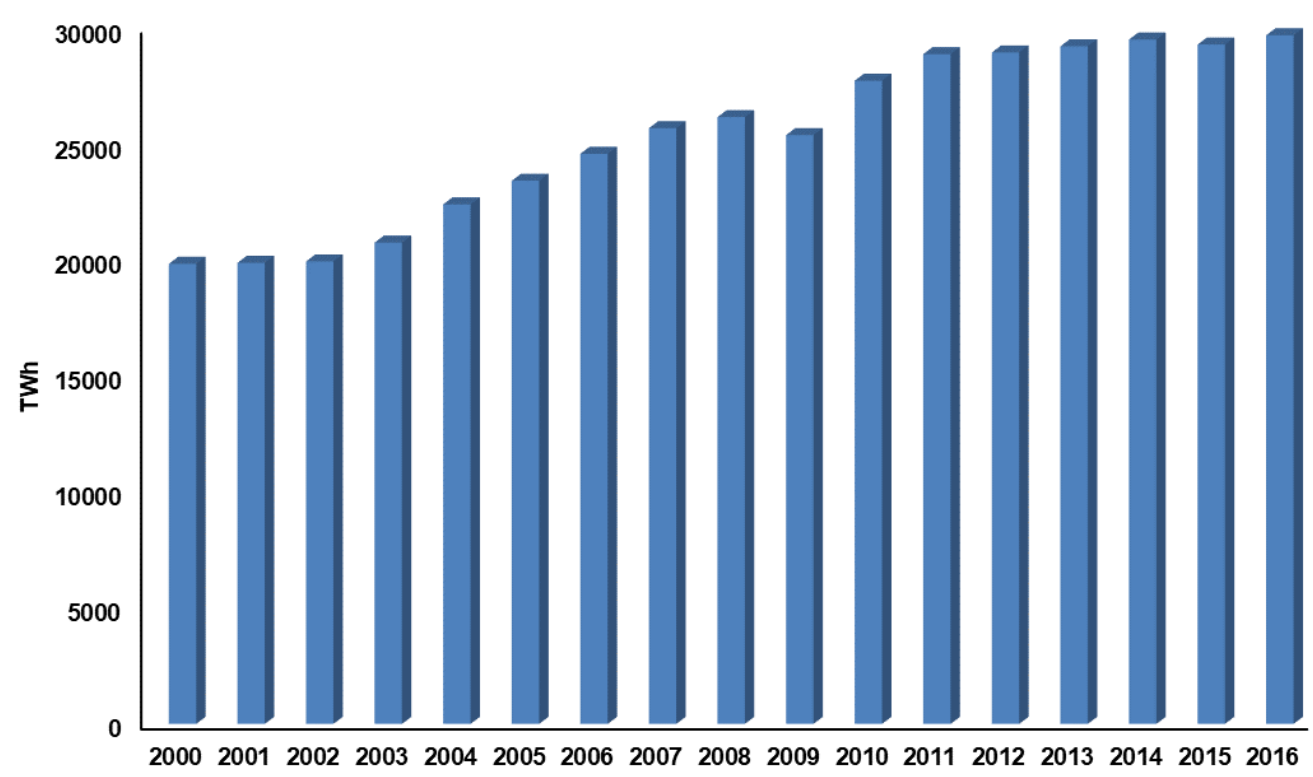

Fonte: IEA (2018) 
Por outro lado, a Figura 7 mostra a participação das energias renováveis na matriz energética mundial, entre os anos 2000-2016. Quanto ao consumo de energias renováveis e não renováveis na indústria, percebe-se situação parecida ao consumo global de energia: apesar do crescimento das energias renováveis em números absolutos, os mesmos não conseguem sustentar crescimento em participação na matriz energética. Enquanto a indústria demonstrava o indicador de $8,7 \%$ de uso de energia renováveis em sua matriz para o ano de 2000, em 2016, sua participação atingiu $7,2 \%$.

Figura 7 - Consumo mundial de energia renovável na indústria em TWh

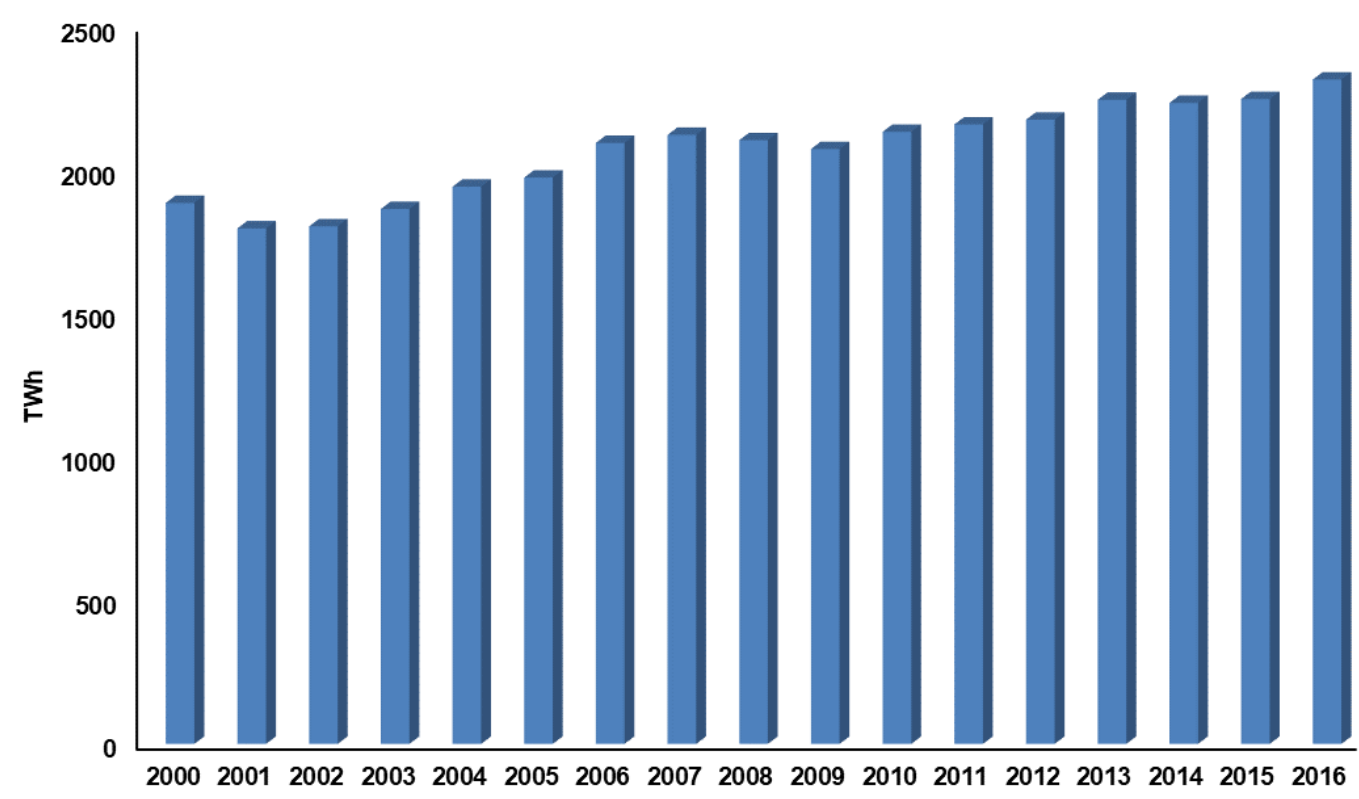

Fonte: IEA (2018)

Dessa forma, verifica-se que o consumo de energia no mundo, apesar do aumento durante a última década e meia, segue em tendência de queda, visto os últimos dados de 2016. Nota-se também que apesar do crescimento das energias renováveis, as mesmas ainda não conseguem crescer o suficiente para ostentar um crescimento em participação na matriz energética mundial, tanto na indústria como no mundo em geral.

Seguindo essa perspectiva, verifica-se que apesar da posição de destaque que o consumo energético mundial possui na sociedade atual, existe complexidade na busca por um consumo mais eficiente. $O$ setor industrial demonstra que vem procurando se reinventar na busca de sistemas energeticamente mais eficientes, de forma a ostentar redução expressiva na participação da matriz energética mundial na presente década. Isso se faz possível com a análise aprofundada dos sistemas industriais, os quais possuem inúmeras oportunidades atuais de melhoria no consumo energético, gerando redução significante nos impactos ambientais da atualidade, como alta emissão de gases e redução de reservas de recursos naturais. 


\section{ENERGIA NO BRASIL}

As escolhas e conquistas da política energética do Brasil se comparam bem a alguns dos desafios energéticos mundiais de maior destaque. Um esforço conjunto de políticas significou que 0 acesso à eletricidade é hoje quase universal em todo o país. Quase $45 \%$ da demanda de energia primária é atendida por energia renovável, tornando o setor de energia do Brasil um dos menos intensivos em carbono do mundo. A demanda total de energia primária dobrou no Brasil desde 1990, liderada pelo forte crescimento no consumo de eletricidade e na demanda por combustíveis de transporte, apoiada no crescimento econômico robusto e na crescente classe média (IEA, 2018).

O Brasil, devido a suas grandes dimensões territoriais e abundantes recursos hídricos, possui a maior parcela da sua produção de energia por meio de usinas hidrelétricas. Muitos investimentos nesse setor foram realizados ao longo dos anos: em meados da década de 1990, 15\% da dívida externa do país se referia as obras de usinas hidrelétricas e isso resultou em custos mais baixos de energia (REIS, 2011).

Em 2001, houve um colapso no sistema energético brasileiro, especialmente na região Sudeste, o maior consumidor de energia do país. Este fato afetou de maneira importante todo 0 sistema energético nacional, assim como fundamentou e impulsionou um maior número de pesquisas voltadas para a eficiência energética e conservação de energia (SOLA et al., 2006).

Os investimentos realizados na infraestrutura voltada para produção de energia elétrica possuem um espaço de tempo de anos para obterem retorno, o qual ocorre pela receita da venda da energia produzida. Entre estas infraestruturas, destacam-se no cenário brasileiro as fontes alternativas de energia, entre elas a energia eólica, a qual vem cada vez mais se tornando competitiva no mercado e se demonstram uma excelente opção em relação ao meio ambiente (RAMOS, 2005).

Para a análise dos dados da oferta e consumo de energia no Brasil, foi utilizado o Balanço Energético Nacional, elaborado pela Empresa de Pesquisa Energética (EPE, 2018) referente ao período de 2008-2017. O estudo dos dados se constituiu em analisar a oferta de energia verificando fontes renováveis e não renováveis, analisar o consumo de energia no Brasil por setor e por fonte, analisando também o setor industrial e o setor de alimentos e bebidas, o qual compreende a indústria do estudo de caso do presente trabalho, como mostra a Tabela 1. 
Tabela 1 - Evolução do consumo de energia no Brasil entre 2008-2017

\begin{tabular}{|c|c|c|c|c|c|c|c|c|c|c|}
\hline Fonte/Ano (\%) & 2008 & 2009 & 2010 & 2011 & 2012 & 2013 & 2014 & 2015 & 2016 & 2017 \\
\hline Petróleo e derivados & 36.7 & 38 & 37.8 & 38.6 & 39.3 & 39.3 & 39.4 & 37.3 & 36.5 & 36.4 \\
\hline Gás natural & 10.3 & 8.8 & 10.2 & 10.2 & 11.5 & 12.8 & 13.5 & 13.7 & 12.3 & 13,0 \\
\hline $\begin{array}{l}\text { Carvão mineral e } \\
\text { coque }\end{array}$ & 5.5 & 4.6 & 5.4 & 5.7 & 5.4 & 5.6 & 5.7 & 5.9 & 5.5 & 5.7 \\
\hline Urânio & 1.5 & 1.4 & 1.4 & 1.5 & 1.5 & 1.4 & 1.3 & 1.3 & 1.5 & 1.4 \\
\hline Outras & 0 & 1 & 0 & 0 & 0 & 1 & 1 & 1 & 1 & 1 \\
\hline Não renováveis & 54.4 & 53.2 & 55.3 & 56.5 & 58.2 & 59.6 & 60.6 & 58.7 & 56.5 & 57.1 \\
\hline Hidráulica & 14.1 & 15.2 & 14 & 14.7 & 13.8 & 12.5 & 11.5 & 11.3 & 12.6 & 12.0 \\
\hline $\begin{array}{l}\text { Lenha } \\
\text { vegetal }\end{array}$ & 11.6 & 10.1 & 9.7 & 9.6 & 9.1 & 8.3 & 8.2 & 8.3 & 8 & 8 \\
\hline $\begin{array}{l}\text { Derivados de cana de } \\
\text { açúcar }\end{array}$ & 17 & 18.1 & 17.5 & 15.7 & 15.4 & 16.1 & 15.8 & 16.9 & 17.5 & 17.0 \\
\hline Eólica & 0 & 0 & 0.1 & 0.1 & 0.2 & 0.2 & 0.3 & 0.6 & 1 & 1,2 \\
\hline Solar & - & - & - & - & - & - & - & 0 & 0 & 0,1 \\
\hline Outras renováveis & 2.9 & 3.3 & 3.4 & 3.5 & 3.3 & 3.4 & 3.7 & 4.1 & 4.4 & 4.6 \\
\hline Renováveis & 45.6 & 46.8 & 44.7 & 43.5 & 41.8 & 40.4 & 39.4 & 41.3 & 43.5 & 42.9 \\
\hline
\end{tabular}

Observa-se, com relação as fontes geradoras de energia no Brasil, que a matriz energética é predominante de energias não renováveis, com destaque aos derivados de petróleo. No entanto, observa-se que o mesmo teve leve decréscimo comparando 2008 com 2017 e, em contrapartida, observa-se um crescimento do uso do GN no mesmo período.

Quanto ao uso de energias renováveis, verifica-se decréscimo no período considerado com relação a participação da energia hidráulica, a qual continua sendo a principal fornecedora de energia elétrica no país. Nota-se que os derivados de cana de açúcar, impulsionados pelo uso do bagaço de cana e do etanol, vem obtendo crescimento ano após ano na participação, estabelecendo-se atualmente como a maior fonte de energia renovável do país.

As usinas hidrelétricas conferem ao sistema energético brasileiro uma grande flexibilidade operacional. A expansão contínua da energia hidrelétrica é cada vez mais limitada pelo afastamento e pela sensibilidade ambiental de grande parte do recurso remanescente, embora 20 GW de capacidade hidrelétrica estejam em construção na região amazônica. A dependência de outras fontes de geração de energia está crescendo, notadamente gás natural, eólica e bioenergia (IEA, 2018).

É possível observar avanço nas energias renováveis no país, apesar de que a participação total das mesmas na matriz energética decresceu no período de 2009 até 2014. Porém, mostra sinal de recuperação nos últimos três anos da análise, impulsionando essa melhora na geração e busca constante por novas fontes, como pode ser verificado em "outras fontes renováveis", as quais 
participaram com 2,9\% na matriz em 2007, passando para 4,6\% em 2017. Além disso, verifica-se crescimento da participação da energia eólica, que representa 1,2\% da matriz energética brasileira (EPE, 2018).

O setor elétrico vem apresentando ao longo dos anos o aperfeiçoamento de tecnologias visando diminuir o impacto ambiental de usinas baseadas no uso de carvão mineral e derivados de petróleo, além de trabalhos e políticas para elevar a participação do GN, considerado ambientalmente mais limpo que outros combustíveis fósseis e o uso de usinas nucleares. O setor segue também incentivando o uso das fontes primárias renováveis, como hidrelétricas, solares, eólicas, biomassa e células à combustível (REIS, 2011).

De acordos com os dados da EPE, a geração de energia elétrica no Brasil em 2017 teve acréscimo de $0,9 \%$ em relação a 2016 , considerando as centrais de serviço público, as quais representam $83,5 \%$ da geração total de energia, como os autoprodutores, com $16,5 \%$ da produção. Os dados de 2017, relativos as fontes geradoras de energia elétrica no Brasil, são mostrados na Figura 8.

Figura 8 - Fontes geradoras de eletricidade no Brasil em \%

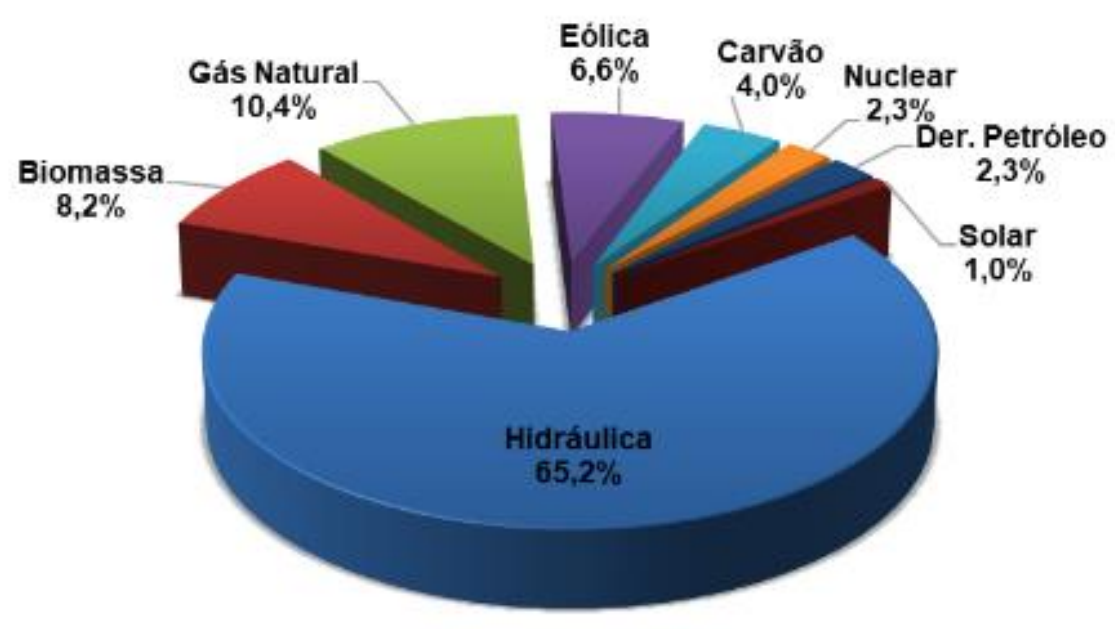

Fonte: EPE (2018)

De acordo com o EPE (2018) o Brasil dispõe de uma matriz elétrica de origem predominantemente renovável. O indicador manteve-se em 80,4\% de 2016 para 2017.

As fontes hidráulicas, principais fornecedoras no mercado brasileiro com $65,2 \%$ de participação na matriz energética brasileira, tiveram redução de 2,6\% na participação em relação a 2016. A energia solar atingiu $935 \mathrm{MW}$ em 2017 contra $24 \mathrm{MW}$ em 2016, representando crescimento expressivo em sua produção, refletido pelo crescente investimento em usinas fotovoltaicas no país. 
Dentre as fontes renováveis, destaca-se também no cenário nacional a produção de energia eólica, que em 2017 foi de 42,373 TW, contra 33,489 TW em 2016 e 21,626 TW em 2015, representando aumento de $95,9 \%$ em dois anos (EPE, 2018).

De acordo com o IEA (2017) o Brasil já é o 8o país em produção absoluta de energia eólica, assim como o 8 $^{\circ}$ país com maior representatividade da energia eólica na cadeia de consumo do mundo. Nesse cenário de energia eólica, destacam-se os Estados Unidos e China com maior geração ( $23 \%$ e $22,2 \%$ da produção mundial, respectivamente). Quanto a porcentagem de energia eólica em seus consumos totais, destacam-se países europeus como Espanha (17,6\%), Alemanha (12,2\%), Inglaterra (11,9\%) e Suécia (10\%).

Verifica-se também, na matriz energética brasileira, a participação das usinas termelétricas, que funcionam a partir da queima de combustíveis fósseis, principalmente o GN (Figura 9). As mesmas são consideradas fontes poluidoras e também emissoras de efluentes aéreos, acarretando em graves consequências ao meio ambiente. Com o uso de carvão, óleo combustível e GN, a contaminação vem a se iniciar na mineração e extração do mesmo até a emissão de produtos químicos contaminantes em seu uso (RAMOS, 2005).

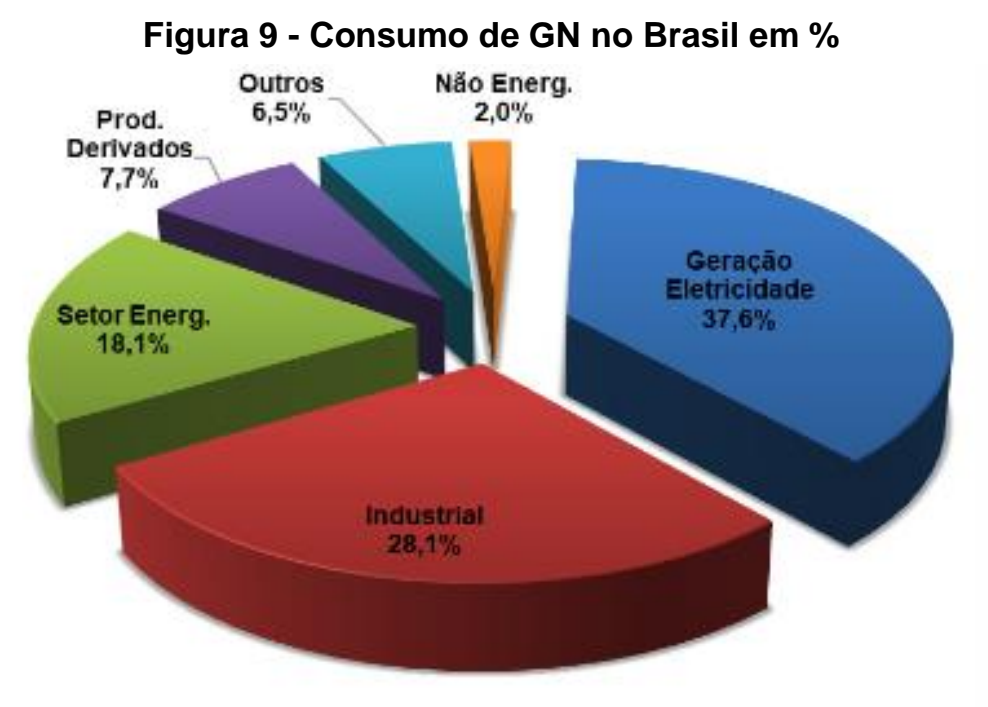

Fonte: EPE (2018)

O consumo de GN no país apresentou em 2017 a participação de 13,2\% na matriz energética nacional (EPE, 2017), com predominância do uso nos setores de geração de eletricidade, no setor energético e no setor industrial. Os dados vão de encontro com estudo da IEA (2018) a qual afirma que o GN continua a ser um combustível atrativo para os setores de energia elétrica e industrial em muitos países. 
A Figura 10 mostra que o consumo de energia no Brasil, assim como o consumo de energia no mundo, sofreu queda devido a grave crise financeira ocorrida em 2008 e 2009. No entanto, após esse período, o país demonstrou retomada no consumo até 2014, quando atingiu o ápice de consumo. Em 2015 e 2016, o consumo decresceu substancialmente, com leve recuperação em 2017 (EPE, 2018).

Figura 10 - Evolução do consumo de energia no Brasil, em TWh

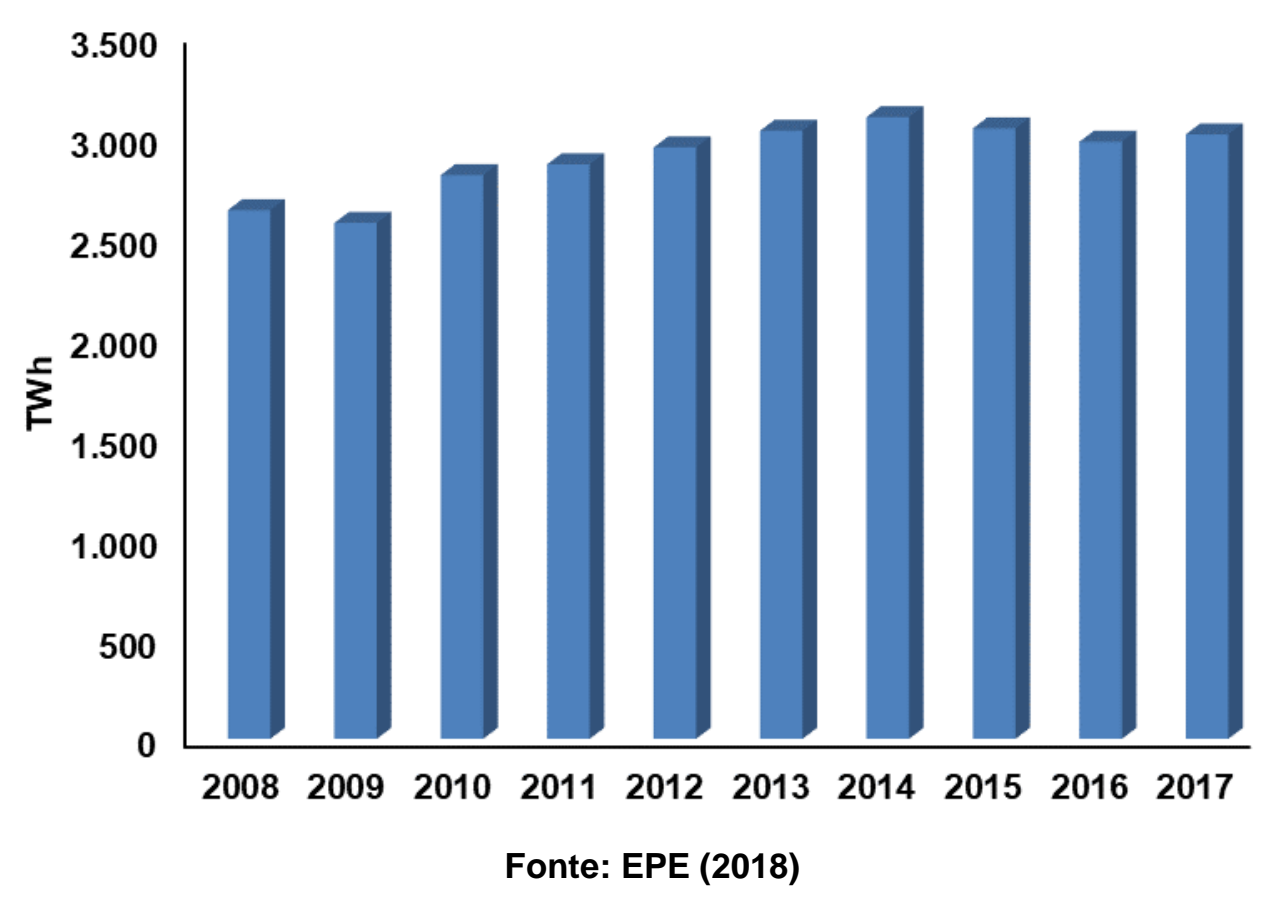

Os dados do consumo de energia na indústria com o crescimento anual são mostrados na Figura 11. 
Figura 11 - Consumo de energia na indústria em TWh

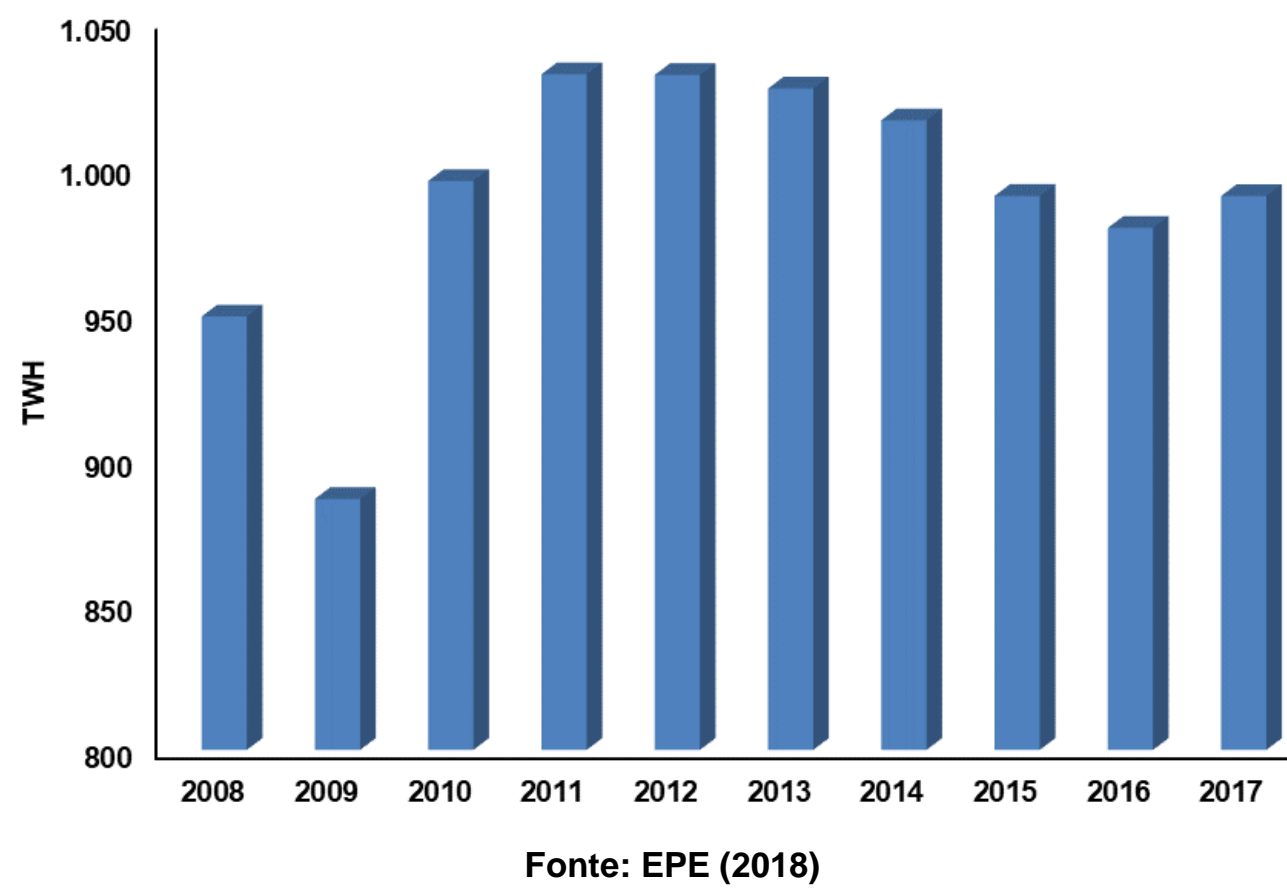

Nota-se que o consumo de energia na indústria está diretamente correlacionado ao consumo de energia geral do Brasil, em que o ápice do consumo foi estabelecido em 2011 e desde então o consumo vem decrescendo com estabilização em 2017, como mostra a Figura 12.

Figura 12 - Participação da indústria no consumo de energia no Brasil em TWh

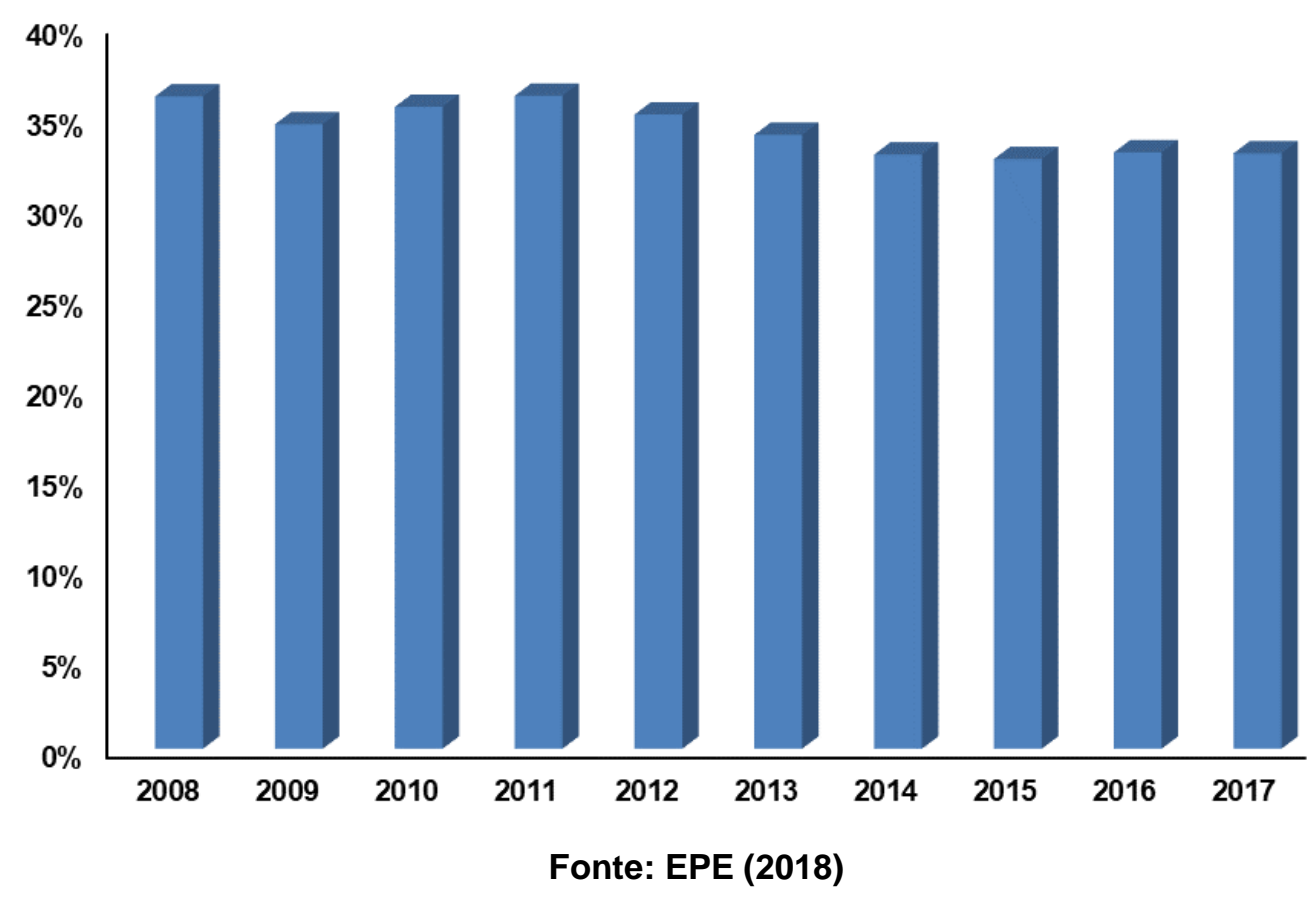

A Figura 12 monstra que o consumo de energia na indústria vem ao longo dos anos perdendo participação na matriz energética brasileira de consumo de energia. Apesar da queda, o número de 
2017 (33\%) ainda é maior que o consumo de energia mundial de 2015 , que foi de $28,9 \%$, demonstrando que o país ainda consome mais energia na indústria na média em relação aos números mundiais.

As Tabelas 2 e 3 mostram a evolução do consumo de energia no Brasil, no período 20082017, com relação aos principais setores industriais. Devido à crise que o país atravessou em 2015, alguns setores foram mais afetados do que outros. Os setores com relação direta com a construção civil foram alguns dos que mais sofreram quedas no consumo absoluto de energia no período 20142017, como o cimento (25,8\%), ferro-gusa e aço (3,1\%), mineração e pelotização $(20,5 \%)$ e cerâmica $(15,2 \%)$.

Tabela 2 - Consumo de energia por área na indústria em \%

\begin{tabular}{lcccccccccc}
\hline \multicolumn{1}{c}{ Área/Ano (\%) } & $\mathbf{2 0 0 8}$ & $\mathbf{2 0 0 9}$ & $\mathbf{2 0 1 0}$ & $\mathbf{2 0 1 1}$ & $\mathbf{2 0 1 2}$ & $\mathbf{2 0 1 3}$ & $\mathbf{2 0 1 4}$ & $\mathbf{2 0 1 5}$ & $\mathbf{2 0 1 6}$ & $\mathbf{2 0 1 7}$ \\
\hline Cimento & 4,7 & 5,0 & 5,0 & 5,7 & 5,8 & 6,0 & 6,1 & 5,6 & 5,1 & 4,7 \\
Ferro-Gusa e Aço & 21,6 & 17,1 & 19,2 & 19,6 & 19,1 & 18,4 & 18,8 & 19,6 & 17,8 & 18,7 \\
Ferro-Ligas & 2,2 & 1,9 & 2,0 & 1,8 & 1,8 & 1,7 & 1,6 & 1,4 & 1,4 & 1,5 \\
Mineração e Pelotização & 3,9 & 3,0 & 3,7 & 3,8 & 3,7 & 3,7 & 3,8 & 3,9 & 3,2 & 3,1 \\
Não ferrosos & 7,3 & 7,0 & 7,6 & 8,0 & 8,0 & 7,9 & 7,6 & 6,6 & 6,7 & 6,6 \\
Química & 8,8 & 9,6 & 8,4 & 8,4 & 8,2 & 7,9 & 7,7 & 8,1 & 8,0 & 8,2 \\
Alimentos e Bebidas & 25,4 & 28,3 & 27,2 & 25,9 & 27,2 & 26,4 & 25,5 & 25,2 & 28,0 & 27,4 \\
Têxtil & 1,5 & 1,5 & 1,4 & 1,4 & 1,3 & 1,2 & 1,2 & 1,1 & 1,0 & 1,0 \\
Papel e Celulose & 11,0 & 12,3 & 11,8 & 11,5 & 11,3 & 12,0 & 12,8 & 13,8 & 14,7 & 14,9 \\
Cerâmica & 5,1 & 5,4 & 5,2 & 5,3 & 5,4 & 5,7 & 5,8 & 5,4 & 5,1 & 5,0 \\
Outros & 8,4 & 8,9 & 8,4 & 8,8 & 8,5 & 9,0 & 9,2 & 9,2 & 9,0 & 8,8 \\
\hline
\end{tabular}

Fonte: EPE (2018)

Tabela 3 - Consumo de energia por área na indústria em TWh

\begin{tabular}{|c|c|c|c|c|c|c|c|c|c|c|}
\hline Área/Ano (TWh) & 2008 & 2009 & 2010 & 2011 & 2012 & 2013 & 2014 & 2015 & 2016 & 2017 \\
\hline Cimento & 44 & 44 & 49 & 59 & 60 & 61 & 62 & 55 & 50 & 46 \\
\hline Ferro-Gusa e Aço & 205 & 151 & 191 & 202 & 197 & 189 & 191 & 195 & 174 & 185 \\
\hline Ferro-Ligas & 21 & 17 & 20 & 18 & 18 & 18 & 17 & 14 & 14 & 15 \\
\hline Mineração e Pelotização & 37 & 26 & 37 & 39 & 38 & 38 & 39 & 39 & 32 & 31 \\
\hline Não ferrosos & 69 & 62 & 76 & 82 & 82 & 81 & 77 & 66 & 66 & 66 \\
\hline Química & 84 & 85 & 84 & 87 & 84 & 81 & 78 & 80 & 78 & 81 \\
\hline Alimentos e Bebidas & 241 & 251 & 270 & 267 & 281 & 271 & 259 & 250 & 274 & 271 \\
\hline Têxtil & 14 & 14 & 14 & 14 & 13 & 13 & 12 & 10 & 10 & 10 \\
\hline Papel e Celulose & 104 & 109 & 118 & 119 & 116 & 123 & 130 & 136 & 144 & 147 \\
\hline Cerâmica & 49 & 48 & 52 & 55 & 56 & 59 & 59 & 54 & 50 & 50 \\
\hline Outros & 80 & 79 & 84 & 90 & 87 & 93 & 93 & 92 & 88 & 87 \\
\hline TOTAL & 949 & 886 & 995 & 1032 & 1032 & 1027 & 1016 & 990 & 979 & 990 \\
\hline
\end{tabular}


O setor de alimentos e bebidas, o qual abrange o objeto de estudo do presente trabalho, responde pelo maior índice de consumo de energia industrial no país. No período de 2008-2017, enquanto o consumo absoluto de energia no setor industrial subiu 4,1\%, o setor teve aumento de $11 \%$. Durante o mesmo período da análise, o setor cresceu $2 \%$ na participação da matriz de consumo energético industrial do Brasil (EPE, 2018).

A indústria de bebidas e alimentos lidera o setor industrial no consumo de energia. $O$ setor configura-se como intensivo no consumo de embalagens, as quais são necessárias para a armazenagem, transporte e exposição dos produtos. Dessa forma, faz-se necessário análises energéticas neste setor, de modo a obter dados fidedignos sobre seus processos produtivos, possibilitando tomada de decisão assertiva em relação a obtenção da eficiência energética do setor.

Verifica-se que o consumo de energia na indústria brasileira caiu nos últimos anos. Autores devem isso a uma passagem do país para setores menos intensivos no consumo de energia, além de esforços do setor em reduzir os custos com energia. Nessa perspectiva, é importante a análise desses processos produtivos, os quais se encontram em expansão no país.

\section{EFICIÊNCIA ENERGÉTICA E GESTÃO DE ENERGIA NO SETOR INDUSTRIAL}

A indústria mundial pode vir a produzir quase o dobro do valor por unidade de energia em 2040. A maioria das economias de energia deverão ser advindas dos setores menos intensivos em energia, como alimentos, bebidas e fabricação de têxteis. Para obter essas economias, os padrões de desempenho dos principais equipamentos industriais devem ser acompanhados de incentivos para a análise de processos produtivos do setor, adoção de sistemas de gerenciamento de energia e melhoria nos sistemas de informação (IEA, 2018).

De acordo com o REN21 (2016) ao final do ano de 2015, 146 países haviam implementado algum tipo de política de eficiência energética. A estatística mostra também que 128 países possuíam na época uma ou mais metas de eficiência energética. Algumas destas políticas buscam fazer uso da sinergia entre eficiência energética e energia renovável, partindo do princípio que medidas de eficiência vem a ter o potencial de abrir espaço para um aumento na participação da energia renovável no consumo mundial de energia.

As medidas de eficiência energética não objetivam unicamente reduzir despesas financeiras, mas também reduzir impactos ambientais negativos dos processos. $O$ uso de indicadores de energia incorpora algumas das mais importantes agendas de impactos ambientais, como a emissão de GEE, 
esgotamento de recursos naturais, esgotamento de camada de ozônio, dessecação, toxicidade, calor residual, ruído e odor, etc. (DO et al., 2014).

O setor industrial é diversificado e inclui agricultura, mineração, construção, indústrias intensivas em energia e manufatura não intensiva em energia. Inovações tecnológicas industriais visam não apenas reduzir o uso de energia, mas também melhorar a produtividade, reduzir custos de capital, reduzir custos de operação, melhorar a confiabilidade, reduzir emissões e melhorar as condições de trabalho (WORRELL et al., 2001).

A energia pode ser economizada no meio industrial de várias maneiras: por meio da introdução de equipamentos ou processos mais eficientes; melhoria de controles; melhoria de monitoramento ou medição de fluxos de energia; recuperação de calor e resíduos e outros (PETRECCA, 1993).

De acordo com Marechal et al., (2005) em se tratando de eficiência energética no meio industrial, as questões chaves são referentes a novas rotas de produção, substituição completa de processos com alto consumo em energia por processos de baixo consumo e processos mais integrados.

Os trabalhos e estudos relativos a eficiência energética no setor industrial começaram a desempenhar importante função na década de 1970. Desde então, quando percebeu-se também a importância de proteger o meio ambiente, houve redução no orçamento de energia utilizando-se de alta eficiência energética (ABDELAZIZ; SAIDUR; MEKHILEF, 2011).

Ainda segundo estes autores (ABDELAZIZ et al., 2011) na indústria existem três abordagens para elevar a eficiência energética: economias de energia via gestão; economia de energia via tecnologias; economia de energia via políticas/regulamentações. Entre as mesmas, destaca-se a Gestão do Consumo Energético, a qual tem como passo inicial a análise aprofundada das entradas e saídas energéticas dos processos industriais.

As operações industriais podem ganhar com o uso eficaz e lucrativo da energia e, portanto, devem tratar a energia como uma questão importante e estratégica. Além disso, os preços crescentes e flutuantes da energia também podem afetar as operações das indústrias (RUDBERG et al., 2013).

A eficiência energética se tornará um fator importante no futuro próximo. Os governos em geral tendem a determinar iniciativas de economia de energia e os preços da energia tendem a se elevar. Assim, as indústrias serão forçadas a colocar um foco maior no gerenciamento de energia para se manter competitivas. Para fazer isso, as empresas precisam lidar com o gerenciamento de energia de muitas perspectivas (DOTY e TURNER, 2009). 
Os custos econômicos e a objeção ambiental à exploração e ao consumo de recursos energéticos convencionais vêm se demonstrando elevados, apresentando-se como o maior desafio para os tomadores de decisão. Da forma que o desempenho econômico e ambiental da transferência de diferentes recursos energéticos do lado da oferta para a demanda é variado. A identificação dos padrões desejados de fluxo de energia sob o custo econômico minimizado é, portanto, um aspecto importante do planejamento (CAl et al., 2009).

De acordo com Doty e Turner (2009) as indústrias podem se utilizar da gestão de energia para reduzir seu consumo e consequentemente custos. Os autores citam que:

- Atividades e programas de baixo custo - redução de 5 a 15\% em até 2 anos;

- Atividades e programas de custo médio com considerável nível de comprometimento redução de 15 a 30\% em 3 a 5 anos;

- Atividades potenciais de longo termo - alto custo e de maior complexidade - 30 a 50\%.

Entre as atividades citadas, destaca-se como atividade de baixo custo e rápido retorno os estudos acadêmicos sobre eficiência energética, os quais podem a partir da análise do emprego da energia nos processos produtivos industriais, demonstrar gargalos e oportunidades de melhoria, gerando retorno financeiro e também redução de impactos ambientais.

Os autores afirmam ainda que grandes economias podem frequentemente serem alcançadas com excelentes resultados e rápidos retornos de investimento, demonstrando que a gestão da energia pode fazer a diferença entre prejuízo e lucro e pode ser uma melhoria competitiva fundamental para a maioria das empresas.

Observa-se na literatura que a questão da eficiência energética vem ultrapassando as agendas comuns, como a financeira e a ambiental e vem se apresentando também como um compromisso com a sociedade. Isso deve-se a crescente conscientização da mesma com a questão energética. Está nessa perspectiva também a busca por energia renováveis, que mesmo apesar de inicialmente demonstrar um custo maior, segue em pleno desenvolvimento com o crescente apoio da sociedade atual.

\section{AVALIAÇÃO DO CICLO DE VIDA}

A ACV é uma técnica estruturada que possui padronização internacional. A ACV visa quantificar os recursos consumidos e as emissões geradas em todas as fases do ciclo de vida de um serviço, processo ou produto, de forma a analisar seus impactos sobre o meio ambiente e estudar questões relacionadas ao esgotamento de recursos naturais associados aos mesmos (IBICT, 2014). 
De acordo com Coltro (2007) a ferramenta Avaliação do Ciclo de Vida (ACV) permite avaliar o impacto ambiental potencial, relativo a um produto ou uma atividade durante seu ciclo de vida, além de identificar quais estágios tem contribuição mais significativa para o processo ou produto estudado.

O objetivo de uma ACV é fornecer conclusões que possam apoiar uma decisão através de resultados compreensíveis. Os resultados do inventário realizado e da avaliação de impacto são discutidos e são identificadas questões ambientais significativas para conclusões e recomendações consistentes com o objetivo e o escopo do estudo. Esta é uma técnica sistemática para identificar e quantificar, verificar e avaliar informações dos resultados obtidos. Essa avaliação pode incluir medidas quantitativas e qualitativas de melhoria, como mudanças no design de produto, processo e atividade; uso de matérias primas, processamento industrial, uso do consumidor e gerenciamento de resíduos (ROY et al., 2009).

Os estudos de ACV tiveram início na década de 1960 com a crise mundial do petróleo, levando a sociedade ao questionamento sobre os impactos e limitações das extrações de recursos minerais e combustíveis fósseis. Com o passar das décadas, o foco também foi direcionado ao consumo de energia, utilização de matérias primas e resíduos gerados (COLTRO, 2007; GUINÉE et al., 2011).

A ideia de avaliações abrangentes de ACV foi concebida nos Estados Unidos no final dos anos 1960 e início dos anos 1970, época em que a complexidade das questões ambientais foi percebida pela comunidade científica. Durante o mesmo período, ideias similares vinham sendo desenvolvidas na Europa. Durante esse período, havia pouco foco do público e muito pouco escrito sobre ACV, o que mudou de fato a partir de 1990 (HUNT e FRANKLIN, 1996).

O estudo analítico formal que se tornou a ACV foi concebido pela primeira vez por Harry E. Teasley Jr. em 1969, o qual ocupava na época cargo de gerente do setor de embalagens na The Coca-Cola Company. Durante um período de meses, ele visualizou um estudo que tentaria quantificar as consequências energéticas, materiais e ambientais de todo o ciclo de vida de uma embalagem, desde a extração de matérias primas até o descarte (HUNT e FRANKLIN, 1996).

Uma das ideias inovadoras da época foi a inclusão de energia na categoria de recursos naturais. Naquela época, não havia interesse concentrado em energia como uma questão ecológica. No entanto, Teasley percebeu que os recursos energéticos se relacionavam com o uso de diferentes materiais, o levando a querer saber as implicações do uso de várias opções de embalagem (HUNT e FRANKLIN, 1996).

Devido às incertezas acerca da técnica a ser aplicada e as dificuldades encontradas, a ideia foi levada ao Midwest Research Institute (MRI) onde o estudo foi conduzido juntamente com demais 
pesquisadores. O estudo em questão não foi publicado por causa de seu conteúdo confidencial, mas foi usado pela empresa no início da década de 1970 como base para tomada de decisão para com embalagens e demais negócios. Um dos resultados a serem destacados sobre este trabalho foi que a empresa conquistou dados suficientes para prosseguir com a ideia de mudar de garrafas de vidro para garrafas plásticas. Anteriormente a isso, os plásticos tinham a reputação de ser ruins em termos ambientais, mas o estudo veio a refutar essa hipótese (HUNT e FRANKLIN, 1996).

A década de 1990 é denominada como a década da padronização da ACV, em função da coordenação de encontros de especialistas da área pela Society of Environmental Toxicology and Chemistry (SETAC), gerando um "Código de Conduta" para a ferramenta. Posteriormente, em 1994, a International Organization for Standardization (ISO) desenvolveu uma metodologia para a ferramenta. Mesmo com a padronização obtida por meio da ISO 14040, a ferramenta é flexível e pode variar entre as diversas aplicações (GUINÉE et al., 2011).

A ACV concentra-se na avaliação do impacto ambiental ao longo do ciclo de vida. Em termos mais específicos, a ACV é um processo objetivo que visa avaliar os ônus ambientais associados a um produto, processo ou atividade, identificando e quantificando os usos e liberações de energia e materiais para o meio ambiente, e também objetiva avaliar e implementar oportunidades de gerar melhorias ambientais. A avaliação inclui todo o ciclo de vida do produto, processo ou atividade, abrangendo materiais de extração e processamento, fabricação, transporte e distribuição, uso, reutilização, manutenção, reciclagem e disposição final (RAMESH et al., 2010; CHAU et al., 2015).

De acordo com Mourad et al., (2002) a ACV é um passo fundamental para o gerenciamento sustentável, em que o gestor necessita do conhecimento sobre a origem das matérias primas, a destinação dos produtos, os resíduos e subprodutos do processo e também os efeitos das emissões geradas para o meio ambiente.

No setor industrial, a ferramenta de ACV é utilizada para avaliar o impacto ambiental dos produtos no ciclo de vida, de modo que quanto mais processos incluídos em um estudo, mais completos e detalhados os resultados se tornam. No entanto, pode-se argumentar que, devido as limitações de tempo e custo, uma maior totalidade pode levar a uma redução na precisão dos resultados, gerando dessa forma resultados superficiais (MENZIES et al., 2007; RAMESH et al., 2010).

A disponibilidade e qualidade, precisão, imparcialidade, idade, propriedades geográficas e tecnológicas, representatividade, transparência e análise de incertezas dos dados influenciam de grande forma nos resultados de um estudo da ACV (MENZIES et al., 2007). Dessa forma, Ferreira (2004) afirma que os requisitos de qualidade acerca dos dados coletados devem ser definidos visando 
atingir os objetivos de um estudo de ACV. Quando um estudo é utilizado para suportar declarações comparativas que serão publicadas, os requisitos de qualidade adotados devem ser referidos.

À medida que o interesse da sociedade cresce para com as áreas que afetam os recursos naturais e o meio ambiente, a ACV vem sendo aperfeiçoada. Uma ampla base de consultores e pesquisadores em todo o mundo tem refinado e expandido ainda mais a metodologia. A necessidade de ir além do inventário para avaliação de impacto tem trazido evolução constante a ACV (CURRAN, 2006).

A inclusão da ACV como base em um processo de tomada de decisão possibilita uma compreensão dos impactos tanto ambientais como na saúde humana que normalmente não são levados em consideração durante a escolha de um produto ou processo. A informação gerada pela ACV disponibiliza uma forma de considerar todos os impactos das decisões, especialmente os que se encontram fora dos limites que são diretamente influenciados pela seleção de um produto ou processo (FERREIRA, 2004).

Ainda segundo Ferreira (2004) os dados de um estudo de ACV quando combinados com informações de outra natureza, como dados referentes a custos e performance, podem ajudar os responsáveis pela tomada de decisão na seleção de produtos ou processos que resultem em um menor impacto para o ambiente.

A ACV demonstra-se muito útil para permitir que os atributos ambientais de um produto, processo ou atividade sejam melhor compreendidos, de fato a permitir que decisões complexas e muitas vezes multidisciplinares sejam tomadas com maior criticidade (MENZIES; TURAN; BANFILL, 2007).

De acordo com a United States Environmental Protection Agency (USEPA, 2001) um estudo de ACV permite:

- Desenvolvimento de uma avaliação sistemática das consequências dos impactos ambientais associados a um determinado processo ou produto;

- Análise dos balanços ambientais associados a um ou mais produtos ou processos específicos, visando ajudar a obter a aceitação das partes interessadas para uma ação planejada;

- Quantificação das emissões ambientais para o ar, água e solo em relação a cada estágio do ciclo de vida e/ou processo contribuinte;

- Auxiliar na identificação de mudanças significativas nos impactos ambientais entre os estágios do ciclo de vida e o meio ambiente;

- Avaliar os efeitos humanos e ecológicos do consumo de materiais e das descargas ambientais para a comunidade local, regional e mundial; 
- Comparar os impactos ecológicos e na saúde humana entre dois ou mais produtos ou processos rivais ou produtos/processos específicos;

- Identificação dos impactos em uma ou mais áreas ambientais específicas de interesse.

A implementação da ACV é desenvolvida em quatro fases (Figura 13), segundo as normas: NBR ISO 14040 (ABNT, 2001); NBR ISO 14041 (ABNT, 2004); NBR ISO 14042 (ABNT, 2004); NBR ISO 14043 (ABNT, 2005):

- Definição do Objetivo e Escopo: Fase fundamental para obtenção do sucesso da aplicação, em que o objetivo, além dos resultados pretendidos, deve também identificar o contexto das decisões. O escopo envolve uma série de itens e características a serem seguidos e coletados, como os aspectos e impactos ambientais a serem abordados, as funções do sistema, as possíveis limitações entre outras características;

- Análise de Inventário: Etapa referente à coleta dos dados e estabelecimento dos procedimentos de cálculo. A fase deve levar em conta que tudo que entra deve ser igual ao que sai, considerando energia e massa. Pela característica iterativa do inventário, devido às incertezas que podem vir a ser observadas na coleta dos dados, os objetivos e o escopo do trabalho podem ser revisitados;

- Avaliação de Impacto: Utiliza como resultados os inventários e faz a interpretação dos seus impactos. Procura estabelecer seleção e definição de categorias dos impactos, assim como os classificar e caracterizar;

- Interpretação: Combinação dos resultados das fases anteriores, promovendo a confrontação dos resultados obtidos com o objetivo e escopo. A interpretação inicia-se com as questões mais significativas encontradas. Pode envolver análise crítica externa. 
Figura 13 - Fases de um estudo de ACV

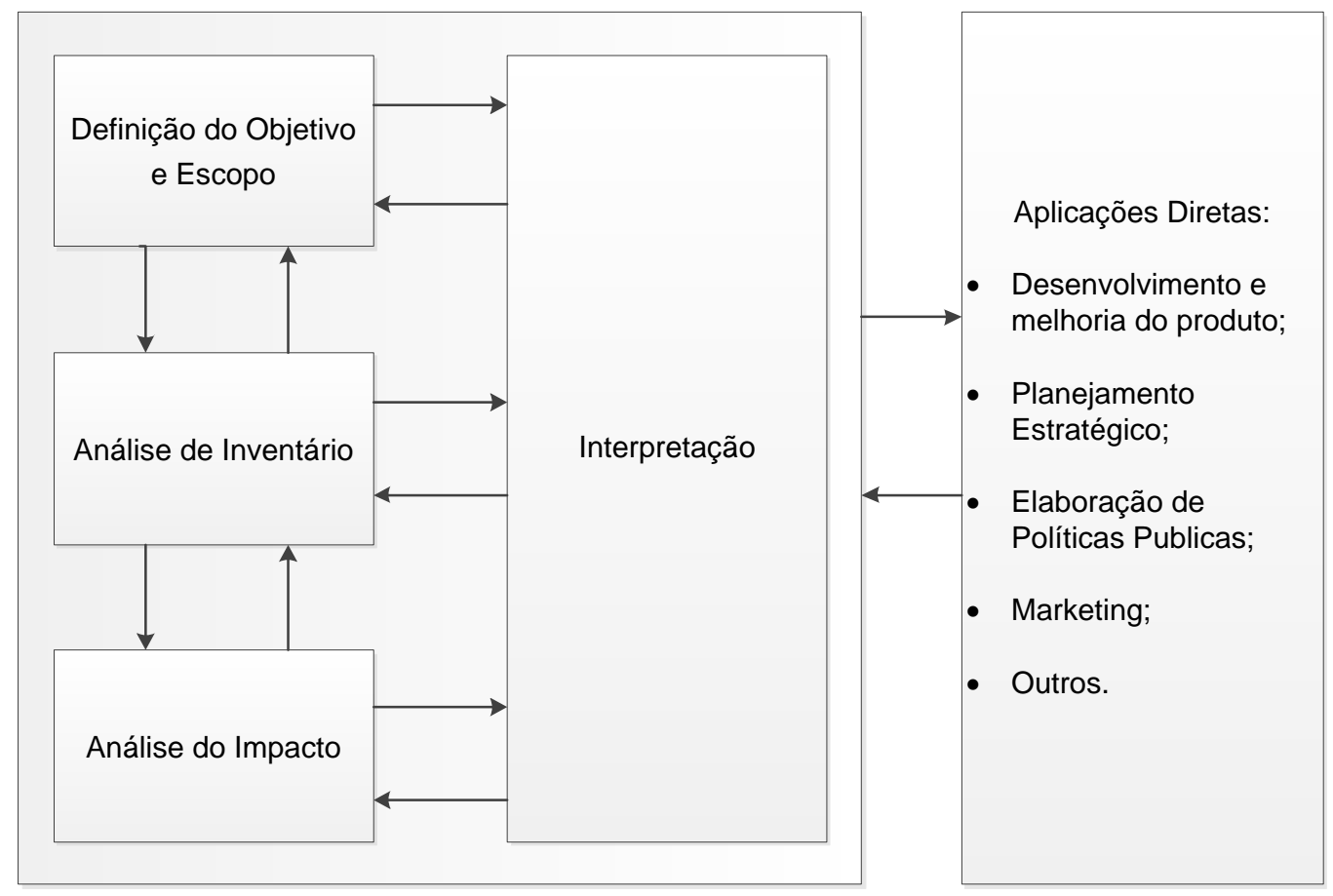

Fonte: ISO 14040 (2001)

\section{ACV DE LATINHAS ${ }^{1}$ DE ALUMÍNIO}

De acordo com Niero et al. (2017) as empresas do setor de embalagens de bebidas estão entre as pioneiras na implementação de estratégias de sustentabilidade ambiental em seus negócios. Os autores ainda afirmam que o primeiro estudo sobre o uso direto e indireto da energia, associado ao ciclo de vida dos produtos, foi realizado no setor de bebidas e que o mesmo levou em consideração o fato da produção das embalagens, tanto primárias como secundárias.

De acordo com Hunt e Franklin (1996) o estudo pioneiro procedido pela The Coca-Cola Company tinha como objetivo concluir se a empresa deveria fabricar suas próprias latas de bebidas e estava analisando uma série de questões relacionadas à fabricação de embalagens. Isso englobou a análise de todas as questões pertinentes a essa decisão, incluindo os impactos ambientais da fabricação e uso das embalagens. Além disso, a possibilidade de usar uma garrafa de plástico estava sendo considerada, o que era uma ideia revolucionária na época. Identificar as questões-chave relacionadas ao uso de garrafas retornáveis em comparação com recipientes descartáveis foi uma parte importante dos objetivos.

O estudo de Hannon (1972) é considerado o percursor após estudo da MRI na área de análise do consumo de energia no ciclo de vida de produtos (HUNT; FRANKLIN, 1996). Buscou avaliar os

\footnotetext{
${ }^{1}$ Latinha: termo que será usado no texto deste estudo.
} 
cenários de consumo energético na ACV de embalagens para bebidas, focando na comparação entre produtos retornáveis e descartáveis, avaliando todas as opções possíveis em relação a reciclagem. $O$ estudo envolveu embalagens primárias e secundárias. Além disso, o estudo concluiu que se a indústria norte americana de bebidas no ano de 1970 fosse convertida inteiramente para embalagens retornáveis, a energia utilizada em todo o sistema da indústria de embalagem para bebidas, seria reduzida em cerca de $40 \%$. O fato se deveu principalmente devido as tecnologias da época, empregadas na área de reciclagem, ser intensivas no consumo de energia e também a falta de políticas relativas ao tema, até então.

Em estudo encomendado pela Associação Americana de Metais conduzido pela PE Americas (2010), foi verificada que a extração e o processamento das matérias primas utilizadas no Al são responsáveis por $67 \%$ de toda a energia usada no processo completo, que envolve a produção do $\mathrm{Al}$ primário (processamento da bauxita), produção do $\mathrm{Al}$ secundário (reciclagem de $\mathrm{Al}$ ), produção das bobinas de $\mathrm{Al}$, produção das latinhas de $\mathrm{Al}$ e a reciclagem de embalagens metálicas usadas. Quando verificado o caso em que o alumínio primário utilizado é fabricado a partir da reciclagem, esse indicador passa a ser de $62 \%$.

Seguindo a mesma perspectiva, o estudo de ACV conduzido por Valt (2004), demonstra que a produção de latinhas de Al no Brasil, com o uso de 100\% de Al reciclável em seu processo, gera economia de energia elétrica de $92 \%$, redução de resíduos sólidos de $91 \%$, redução de efluentes líquidos de $57 \%$, redução de emissão atmosférica de $65 \%$ e redução de consumo de água de $20 \%$, em relação à produção somente com utilização de Al primário.

Em estudo conduzido por Detzel e Mönckert (2009) para comparativos usando ACV entre latinhas de $\mathrm{Al}$ e garrafas de vidro retornáveis no mercado cervejeiro alemão, notou-se redução significante nos impactos ambientais relativos a mudanças climáticas pelo uso da lata de $500 \mathrm{ml}$ ao invés da lata convencional de $300 \mathrm{ml}$, devido a sua maior capacidade de envase. Os autores afirmam que a reciclagem tem participação expressiva nos bons resultados ambientais da latinha de Al.

O Quadro 1 abaixo demonstra alguns trabalhos de ACV que abordam as latinhas de Al:

Quadro 1 - Alguns trabalhos de ACV que abordam as latinhas de Al

\begin{tabular}{|c|c|c|}
\hline Objetivo & Pais & Referência \\
\hline $\begin{array}{l}\text { ACV dos impactos ambientais das embalagens utilizadas no mercado } \\
\text { grego para cervejas e refrigerantes (PET, latinha de aço, latinha de Al } \\
\text { e garrafa de vidro). }\end{array}$ & Grécia & $\begin{array}{c}\text { Diakoulaki e } \\
\text { Koumoutsos (1990) }\end{array}$ \\
\hline $\begin{array}{l}\text { ACV com ênfase na Análise de Inventário de Ciclo de Vida, para a lata } \\
\text { de alumínio de } 350 \mathrm{ml} \text {, representando a média da produção brasileira } \\
\text { e participação de mercado. }\end{array}$ & Brasil & $\begin{array}{c}\text { Gatti, Quieroz e Garcia } \\
(2008)\end{array}$ \\
\hline
\end{tabular}




\begin{tabular}{|c|c|c|}
\hline $\begin{array}{l}\text { ACV para comparar os impactos ambientais de garrafas PET e latas } \\
\text { de alumínio usadas para embalagens de bebidas no Brasil. }\end{array}$ & Brasil & Almeida et al. (2009) \\
\hline $\begin{array}{l}\text { Avaliar o impacto ambiental da fabricação e descarte das opções de } \\
\text { embalagem para três bebidas: suco (cartonadas assépticas, vidro e } \\
\text { polietileno) cerveja (latinha de Al, vidro e polietileno) e água (PET e } \\
\text { vidro). }\end{array}$ & Espanha & $\begin{array}{l}\text { Pasqualino, Meneses e } \\
\text { Castells (2011) }\end{array}$ \\
\hline $\begin{array}{l}\text { Avaliar por meio da ACV os impactos ambientais gerados pelas } \\
\text { embalagens para bebidas utilizadas pela PepsiCo dos Estados } \\
\text { Unidos. }\end{array}$ & $\begin{array}{l}\text { Estados } \\
\text { Unidos }\end{array}$ & Ghosh et al. (2012) \\
\hline $\begin{array}{l}\text { Avaliar os impactos ambientais através da ACV da latinha de Al e da } \\
\text { garrafa retornável de vidro no mercado de cervejas alemão. }\end{array}$ & Alemanha & $\begin{array}{l}\text { Detzel e Mönckert, } \\
2009\end{array}$ \\
\hline $\begin{array}{l}\text { Avaliação da performance ambiental através da ACV de dois } \\
\text { diferentes modelos de coleta de embalagens para bebidas (latinhas de } \\
\text { Al, garrafas de vidro e embalagens cartonadas) no mercado espanhol. }\end{array}$ & Espanha & Itoiz et al., 2011 \\
\hline $\begin{array}{l}\text { Avaliar através da ACV os impactos ambientais pelo tipo e tamanho } \\
\text { de embalagens diferentes tipicamente usados no envase de } \\
\text { refrigerantes no Reino Unido: garrafas de vidro }(0,75 \text { I), latas de } \\
\text { alumínio }(0,33 \text { I) e garrafas de polietileno tereftalato (PET) ( } 0,5 \text { e } 2 \text { I). }\end{array}$ & $\begin{array}{l}\text { Reino } \\
\text { Unido }\end{array}$ & Amienyo et al. (2013) \\
\hline $\begin{array}{l}\text { Desenvolvimento da ACV com visão geral das etapas de } \\
\text { processamento das latinhas desde a matéria prima até o produto final } \\
\text { e verificar o processo de reciclagem em relação a suas vantagens em } \\
\text { termos de economia, meio ambiente e energia. }\end{array}$ & Romênia & $\begin{array}{l}\text { Bungardean, Soporan } \\
\text { e Salanta (2013) }\end{array}$ \\
\hline $\begin{array}{l}\text { ACV para avaliar o cálculo do impacto ambiental durante a reciclagem } \\
\text { de alumínio, examinar os métodos de reciclagem e expressar e } \\
\text { quantificar as perdas de diluição e qualidade durante a reciclagem. }\end{array}$ & Bélgica & $\begin{array}{l}\text { Paraskevas et al. } \\
\qquad(2013)\end{array}$ \\
\hline $\begin{array}{l}\text { Avaliar através da ACV seis métodos utilizados para reciclagem e } \\
\text { aplicar a dois estudos de caso: latinha de Al e copo de poliestireno } \\
\text { descartável. }\end{array}$ & Holanda & $\begin{array}{l}\text { Van der Harst, Potting } \\
\text { e Kroeze (2015) }\end{array}$ \\
\hline $\begin{array}{l}\text { ACV para avaliar o cálculo de impacto ambiental da reciclagem de } \\
\text { alumínio, expressar, quantificar e integrar perdas de diluição e } \\
\text { qualidade e determinar o material de entrada ótimo para o processo } \\
\text { de reciclagem a partir de uma perspectiva ambiental. }\end{array}$ & Bélgica & $\begin{array}{l}\text { Paraskevas et al. } \\
\qquad(2015)\end{array}$ \\
\hline $\begin{array}{l}\text { Comparar o impacto ambiental associado a diferentes níveis de dois } \\
\text { requisitos de certificação "Cradle to Cradle" usando ACV e identificar } \\
\text { os principais desafios e desvantagens no uso combinado de ACV e } \\
\text { "Cradle to Cradle" para latinhas utilizadas pela Cervejaria Carlsberg's } \\
\text { no âmbito da economia circular. }\end{array}$ & Dinamarca & Niero et al. (2016) \\
\hline $\begin{array}{l}\text { Aplicação da ACV para avaliação dos impactos ambientais de } \\
\text { embalagens para bebidas em diferentes materiais: garrafas de vidro } \\
(300 \mathrm{ml}) \text {, latinhas de } \mathrm{Al}(330 \mathrm{ml}) \text { e garrafas PET }(2000 \mathrm{ml}) \text {. }\end{array}$ & Palestina & Saleh (2016) \\
\hline $\begin{array}{l}\text { Investigar por meio da ACV os efeitos da inclusão de diversos tipos de } \\
\text { sucata de Al na liga utilizada para produção de latinhas. }\end{array}$ & Dinamarca & Niero e Olsen (2016) \\
\hline $\begin{array}{l}\text { ACV de cinco diferentes materiais de embalagens em diferentes } \\
\text { formatos (PET - } 500 \mathrm{ml}, 1000 \mathrm{ml}, 1500 \mathrm{ml} \text { e } 2000 \mathrm{ml} \text { recarregável e } \\
\text { descartável, latinha de Al - } 330 \mathrm{ml} \text { e } 500 \mathrm{ml} \text {, embalagens de papel } \\
\text { cartonado - } 1000 \mathrm{ml} \text {, garrafas de PLA (ácido poliláctico) - } 1500 \mathrm{ml} \text { e } \\
\text { garrafas de vidro - } 330 \mathrm{ml} \text { e } 500 \mathrm{ml} \text { retornável ou não retornável.) }\end{array}$ & Hungria & $\begin{array}{l}\text { Simon, Ben Amor e } \\
\text { Foldényi (2016) }\end{array}$ \\
\hline $\begin{array}{l}\text { Comparar por meio da ACV os potenciais impactos ambientais do } \\
\text { sistema de latinhas de bebidas com auto resfriamento com as latinhas } \\
\text { convencionais. }\end{array}$ & $\begin{array}{l}\text { Reino } \\
\text { Unido }\end{array}$ & Arena et al. (2017) \\
\hline
\end{tabular}


ACV comparativa de oito cenários de reciclagem de latinhas, incluindo diferentes tecnologias de triagem e reciclagem, configurações da lata e opções de gerenciamento de resíduos no mercado do Reino Unido.

Reino

Unido

\section{Fonte: Autoria própria}

Com as informações coletadas no Quadro 1, verifica-se boa participação de trabalhos de ACV em latinhas de $\mathrm{Al}$ com foco na área de reciclagem. Isso alinha-se com o fato de que $75 \%$ do $\mathrm{Al}$ produzido desde 1880 ainda segue em uso nos dias atuais devido a possibilidade da infinita reciclagem do material, sendo atualmente o segundo metal mais utilizado mundialmente atrás do aço (LIU e MULLER, 2012).

Verifica-se também grande participação de estudos na área onde são verificados os impactos ambientais de diversos tipos de embalagens para bebidas para efeito de comparação entre as mesmas assim como estudos que avaliam o ciclo completo da latinha, desde a produção do alumínio até o seu descarte ou reciclagem, abordando de forma breve e superficial o processo produtivo em si das latinhas.

Verifica-se que as latinhas de Al possuem participação considerável na literatura de ACV, porém, nota-se a ausência de trabalhos que envolvam a exploração a fundo dos impactos ambientais gerados exclusivamente pelo processo produtivo das latinhas de Al.

\section{AVALIAÇÃO DO CICLO DE VIDA ENERGÉTICO}

A totalização da quantidade energética empregada na manufatura de produtos ou serviços vem a requisitar sistema organizados de avaliação na busca da análise energética. Dessa forma, torna-se importante o estudo de como são consumidos os recursos energéticos, de forma a entender o fluxo energético de um determinado processo produtivo (TAVARES, 2006).

A ACV e suas derivativas visam analisar os problemas ambientais associados a produtos e serviços ao longo de todo o seu ciclo de vida. Parte substancial desses problemas ambientais relaciona-se com a energia e os conceitos termodinâmicos envolvidos. Para tanto, pode-se realizar uma análise específica dos aspectos energéticos do ciclo de vida de um produto ou processo (HAES e HEIJUNGS, 2007).

A ACV dos sistemas de energia é um importante campo de estudo, tanto em seu grande número de publicações quanto em seu interesse político. Os estudos podem abranger uma pequena escala, como a comparação de dois tipos de baterias, até a grande escala, como de comparar as estruturas de geração de eletricidade de países inteiros. A média escala, mais comum entre estes estudos, abrange sistema produtivos industriais (HAES e HEIJUNGS, 2007). 
As aplicações da ACV têm se mostrado complexas, levando assim ao surgimento de outros caminhos visando estudar impactos em processos produtivos de qualquer natureza. Nessa perspectiva, a ACVE surge como alternativa para estudos iniciais que objetivam a contabilização de energia, gerando assim conhecimento acerca do processo estudado e possibilitando posterior aplicação de uma ACV completa (PEDROSO, 2015).

A ACVE é uma forma de ACV que vem sendo empregada nas últimas décadas devido aos esforços voltados ao aumento eficiência energética no setor industrial (FAY et al., 2000). De acordo com Carminatti Junior (2012) um estudo da ACV é extenso e por consequência demanda grande quantidade de recursos e conhecimento do sistema a ser estudado. Nessa perspectiva, é importante o desenvolvimento de ferramentas e metodologias como a ACVE, que auxiliem na obtenção de resultados significativos com menor tempo e consumo de recursos. Assim, enquanto a ACV avalia os impactos de uma forma geral, a análise derivativa chamada de ACVE concentra-se na energia como a única medida do impacto ambiental (MENZIES et al., 2007).

De acordo com Tavares (2006) a ACVE é uma forma simplificada e significativa para avaliação de impactos ambientais importantes, avaliando primariamente a energia utilizada e podendo ser estendida a emissão de GEE. A ACVE, fundamentada na ACV, prioriza o inventário de dados de consumo energético, diretos e indiretos. De acordo com Hubermann e Pearlmutter (2008) a ACVE se utiliza das mesmas 4 etapas da ACV como demonstrado na Figura 13. No entanto, a energia é utilizada como única medida de impacto ambiental. Sendo assim, trabalhos de ACVE devem respeitar as mesmas etapas de um trabalho convencional de ACV, regidas pela norma ISO 14040, porém, considerando somente como entrada e saída do processo a questão energética envolvida no objeto de estudo.

A ACVE pode ser utilizada tanto para avaliação da energia primária quanto da secundária. A energia primária é relativa a energia extraída diretamente do meio ambiente, como carvão mineral ou GN. A energia secundária é relativa a energia produzida a partir de outras fontes primária, como exemplo a hidroeletricidade (CHAU et al., 2015).

A ACVE não foi desenvolvida para substituir a ACV, mas para comparar e avaliar a energia incorporada em materiais, a energia usada durante a fase operacional e também durante a reciclagem e o descarte. A metodologia é frequentemente utilizada para determinar o consumo e avaliar possíveis economias de energia durante a vida do produto ou de um edifício. A avaliação do carbono no ciclo de vida é compreendida na ACVE, utilizando-se das estruturas energéticas predominantes para converter Joules de energia em quilogramas de carbono (MENZIES et al., 2007). 
A etapa de inventário da ACVE envolve a quantificação real de entradas de energia para todas as etapas do sistema ou processo a ser estudado nas diferentes fases do seu ciclo de vida. Todos os valores de energia são expressos em termos de energia primária, usando a unidade comum de Joules, a fim de permitir comparações e adições entre eles (HUBERMANN e PEARLMUTTER, 2008).

Apesar da técnica ACVE ser utilizada em sua maioria para estudos na área de engenharia civil (MENZIES et al., 2007; CABEZA et al., 2014) também pode se aplicar com resultados expressivos no setor industrial (FITCH e COOPER, 2004; SONG et al., 2009; PAPONG e MALAKUL, 2010).

A ACVE em processos produtivos se aplica através de três principais conceitos: identificação dos tipos de energia utilizada, identificação das fontes de consumo de energia e aferição ou estimativa do fluxo de energia na planta. Os cálculos de consumo de energia devem ser efetuados por etapa do processo a fim de obter o consumo geral de uma linha de produção. $O$ consumo energético deve ser calculado com base nos valores de eficiência de máquina e potência nominal ou aferida (PRAJWAL et al., 2018).

Em estudo conduzido por Benton et al. (2017) a ACVE foi aplicada para quantificar as demandas de energia de cada estágio do ciclo de vida (materiais, fabricação, transporte, uso e descarte em fim de vida) de um gerador abastecido à diesel de $455 \mathrm{~kW}$. Os resultados revelaram que os geradores a diesel consumiam a maior parte da energia ( $>95 \%$ de todo o ciclo de vida) durante a fase de uso, seguidos pelos materiais, transporte e fabricação. Dessa forma, verificou-se que o aumento da eficiência no consumo de combustível pode vir a gerar os maiores benefícios energéticos e ambientais (BENTON et al., 2017).

Filion et al. (2004) desenvolveram uma ACVE que objetiva quantificar os gastos de energia nos estágios de fabricação, uso e fim de vida dos tubos de um sistema de distribuição de água. $\mathrm{O}$ estudo prossegue aplicando os resultados do inventário de energia ao caso dos túneis de abastecimento de água da cidade de Nova York (Estados Unidos da América). Foram utilizadas quatro frequências de substituição de tubos: 10, 20, 50 e 100 anos. $O$ estudo concluiu que, devido aos grandes gastos energéticos em reparos durante a etapa de uso, o período de substituição de tubos de 50 anos produziu o menor gasto total de energia na soma dos três estágios do ciclo de vida.

Em estudo realizado na Tailândia, Papong e Malakul (2010) utilizaram a ACVE para avaliação energética da produção de etanol a partir da mandioca. O escopo abrangia todas as etapas do ciclo de vida da produção de etanol: cultivo, processamento de cavacos, transporte e conversão de etanol. Os dados de entrada e saída foram coletados em locais de plantio e usinas de etanol. A partir da análise de energia realizada, os resultados apontaram que o etanol à base de mandioca tem razão de 
energia líquida negativa, o que acontece devido ao fato do consumo de energia ser maior na sua produção do que a energia propriamente disponível pelo combustível produzido.

A partir da ACVE, o estudo de Singh e Gundimeda (2014) objetivou determinar a eficiência energética do ciclo de vida de combustíveis utilizados na cozinha doméstica na Índia. Foram analisados o gás liquefeito de petróleo (GLP), GN, biogás, querosene, carvão vegetal, lenha, eletricidade, estrume e biomassa. $O$ estudo conclui que entre os combustíveis fósseis analisados para o caso, o GN tem a maior eficiência energética, enquanto o carvão vem a ser a opção de combustível fóssil menos eficiente. Em relação aos combustíveis tradicionais de biomassa, a eficiência energética do ciclo de vida vem a ser menor do que o dos combustíveis para cozinha comercial, como o GLP e o querosene. $O$ estudo também conclui que a eficiência energética do biogás é comparável ao GLP, apresentando-se como uma opção potencial sustentável de combustível para cozinhar no contexto indiano.

Em estudo desenvolvido por Song, Youn e Gutowski (2009) a ACVE foi realizada para avaliar o consumo de energia na produção de compósitos reforçados com fibras e comparar a aplicação do material com o aço e o alumínio na indústria automobilística de ônibus e caminhões. Todos os estágios do ciclo de vida foram avaliados: produção de matérias primas, fabricação, uso e descarte. Após verificar que o estágio de uso dos automóveis é predominante no balanço energético, os autores concluem que materiais leves são mais favoráveis para economizar a energia durante o ciclo de vida. Os resultados também mostram que as peças de compósito reforçadas com fibras são mais energeticamente eficientes do que as de aço, mas não do que as de alumínio.

Em trabalho realizado por Fitch e Cooper (2004) a ACVE foi empregada para fins de análise e seleção de materiais para um feixe de reforço de para-choques em um veículo automotivo de 1030 $\mathrm{kg}$. Do ponto de vista energético, entre os materiais analisados, o compósito de fibra de vidro e as vigas de aço de alta resistência apresentaram o melhor desempenho.

Portanto, a ACVE, que apesar de amplamente utilizada no setor de construção civil e ainda pouco utilizada no setor industrial, mostra-se eficiente na construção de balanços energéticos de processos produtivos. A partir desses balanços, verifica-se consistência de dados necessária para tomadas de decisão assertivas no cenário energético, principalmente em relação à procura por métodos de produção, combustíveis e materiais mais eficientes energeticamente.

Contrariamente a ACV, que possui grande participação nas pesquisas atuais de ACV, a ACVE não possui aplicações voltadas a indústria de embalagens, sejam ela de bebidas ou para outros produtos. 


\section{EMBALAGENS - LATINHAS DE ALUMÍNIO}

De acordo com a Associação Brasileira de Embalagem (ABRE, 2018) as indústrias de embalagem ocupam a linha de frente nas políticas de sustentabilidade. São exemplos disso, o aproveitamento máximo de matérias primas, controle rigoroso de produção, envase eficaz, gestão de recursos, criação de associações, investimentos em pesquisas e desenvolvimento de tecnologias e processos de reciclagem de produtos e resíduos, certificações de qualidade, fomento às cooperativas, incentivo à logística reversa, racionalização e redução do uso de energia, combustíveis fósseis e água, o treinamento de pessoas e apoio às comunidades.

Liu e Muller (2012) afirmam que $1 \%$ do alumínio produzido mundialmente encontra-se empregado na indústria de embalagens. Para o caso brasileiro, a Associação Brasileira do Alumínio (ABAL, 2018) mostra que $38,8 \%$ do alumínio produzido no mercado brasileiro é destinado para embalagens, sendo o setor com o maior consumo doméstico.

A indústria alimentícia surgiu juntamente com o processo de industrialização e teve um crescimento acentuado na década de 1920, com diversos investimentos no setor agropecuário. O capital nacional prevaleceu até a década de 1960, quando os investimentos vindos do exterior começaram a predominar, perfazendo um grande aumento de empresas multinacionais e gerando um grande avanço tecnológico (RAMOS, 2005).

A latinha de Al é um dos recipientes de bebidas mais populares do mundo (EAA, 2018). Apesar de sua aparência simples e compacta, a produção de latinha de Al é complexa. O metal utilizado pelos fabricantes de latinha de Al demanda a mesma precisão que o de metal utilizado em uma asa de avião. Os engenheiros que desenvolvem e aperfeiçoam a fabricação destas embalagens metálicas utilizam-se dos mesmos métodos analíticos usados em veículos espaciais (HOSFORD e DUNCAN, 1994).

De acordo com Cervieri Júnior et al. (2014) as latinhas possuem características para atender hábitos de consumo em que a conveniência para transportar e consumir a bebida em pequenas quantidades é importante. Além disso, as embalagens são utilizadas pelos grandes fabricantes como meio de comunicação, reforçando sua marca no mercado e mantendo um relacionamento com os consumidores. Ainda segundo os autores, as grandes companhias costumam envasar seus produtos em várias latas temáticas durante o ano, como as latas de datas comemorativas ou destinadas a eventos esportivos ou culturais.

O primeiro registro de bebidas em latas é datado de 1933. A lata, produzida em caráter de teste pela American Can Company (AMCC) foi utilizada no envase da cerveja Kruger's Special Beer, 
em Richmond, Virginia (EUA) mas não foram disponibilizadas ao público. No entanto, em 1935, as primeiras latas de cerveja destinadas ao consumidor final foram envasadas em aço pelo mesmo fabricante, feitas no padrão $12 \mathrm{Oz}$ (similar a atual latinha de $350 \mathrm{ml}$ ) (MAXWELL, 1993; HOSFORD e DUNCAN, 1994).

Ainda segundo Maxwell (1993) as primeiras latinhas de bebidas produzidas 100\% com Al são datadas de 1959, ainda produzidas em três componentes/peças: tampa, corpo e fundo. A empresa pioneira no envase de latinhas foi a cervejaria norte americana Coors. Esta ação veio a revolucionar o modo de embalar cerveja. As latinhas de duas peças (tampa e corpo), como são produzidas até os dias atuais, foram lançadas em 1963 pela Reynolds Metals Company e tornaram-se o padrão da indústria conforme o passar dos anos. Em 1967, houve aumento expressivo na venda de latinhas de Al devido às marcas Pepsi e Coca-Cola, que adotaram o produto ao seu portfólio de embalagens. De acordo com a Associação Brasileira dos Fabricantes de Latas de Alumínio (ABRALATAS, 2018) em 1985, a latinha alcançou o primeiro lugar em popularidade nos Estados Unidos.

No caso brasileiro, a história remete ao ano de 1982, quando o país alcançou a autossuficiência de Al primário, condição determinante para a produção das latinhas. Com essa condição estabelecida, houve o surgimento de incentivos para que o Al passasse a ser utilizado em diversos outros produtos que antes eram importados ou fabricados com outros materiais (ABRALATAS, 2018). Em frente ao cenário econômico e industrial brasileiro, estima-se que o Brasil continue aumentando sua taxa de uso de $\mathrm{Al}$ de $6 \mathrm{~kg}$ per capita para taxas semelhantes às nações desenvolvidas, maiores a $8 \mathrm{~kg}$ per capita (BAUXITE INDEX, 2018).

Em 1986, a empresa Alcan instalou em Pindamonhangaba (SP) um laminador específico para a produção de Al para latinhas. O equipamento foi o primeiro do gênero de toda a América Latina. Após instalação e início da produção, iniciaram-se os testes com o Al produzido em laboratórios no exterior (ABRALATAS, 2018).

No Brasil, deu-se início a produção de latinhas de Al em 1989, sendo que no ano de 1990, o volume produzido foi de 400 milhões de latinhas. Para efeitos de comparação, em 2016, foram produzidas 25,4 bilhões de embalagens, demonstrando assim um crescimento acentuado para um período de 26 anos do produto no mercado brasileiro. A Figura 14 mostra a evolução da produção de embalagens metálicas (ABRALATAS, 2018). 
Figura 14 - Produção de latinhas de Al no Brasil

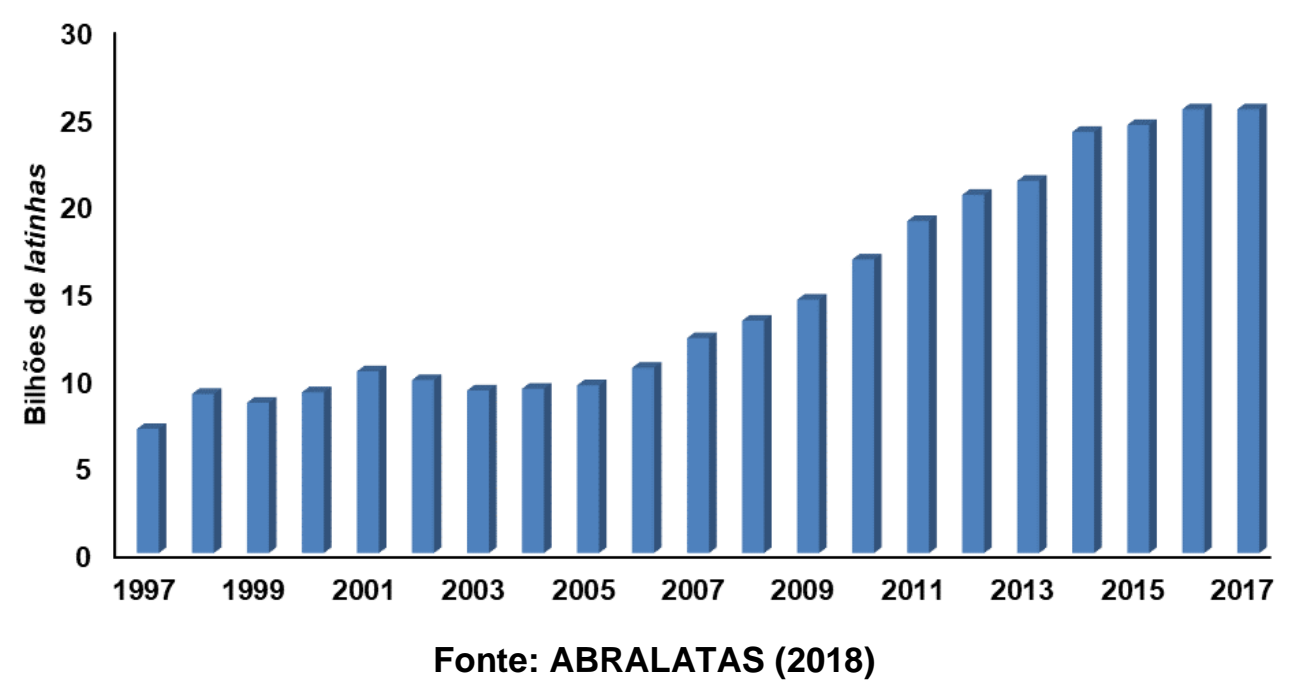

Observa-se que entre os anos de 2004 e 2013 houve um crescimento de 50\% neste mercado, devido principalmente ao crescimento do poder aquisitivo da população (CERVIERI JÚNIOR et al., 2014). Visualiza-se que para o mesmo período, o setor de produção de latinhas cresceu 129\%, demonstrando que o produto aumentou a sua penetração de mercado ao longo dos anos.

De acordo com o aumento da produção ao longo dos anos, novas fábricas se instalaram no país. O mercado contou com somente um fabricante até 1996, quando se instalaram mais dois concorrentes no mercado, alavancando a produção brasileira de latinhas. Os dados de capacidade instalada de produção no Brasil são mostrados na Figura 15:

Figura 15 - Capacidade instalada de fabricação de latinhas no Brasil

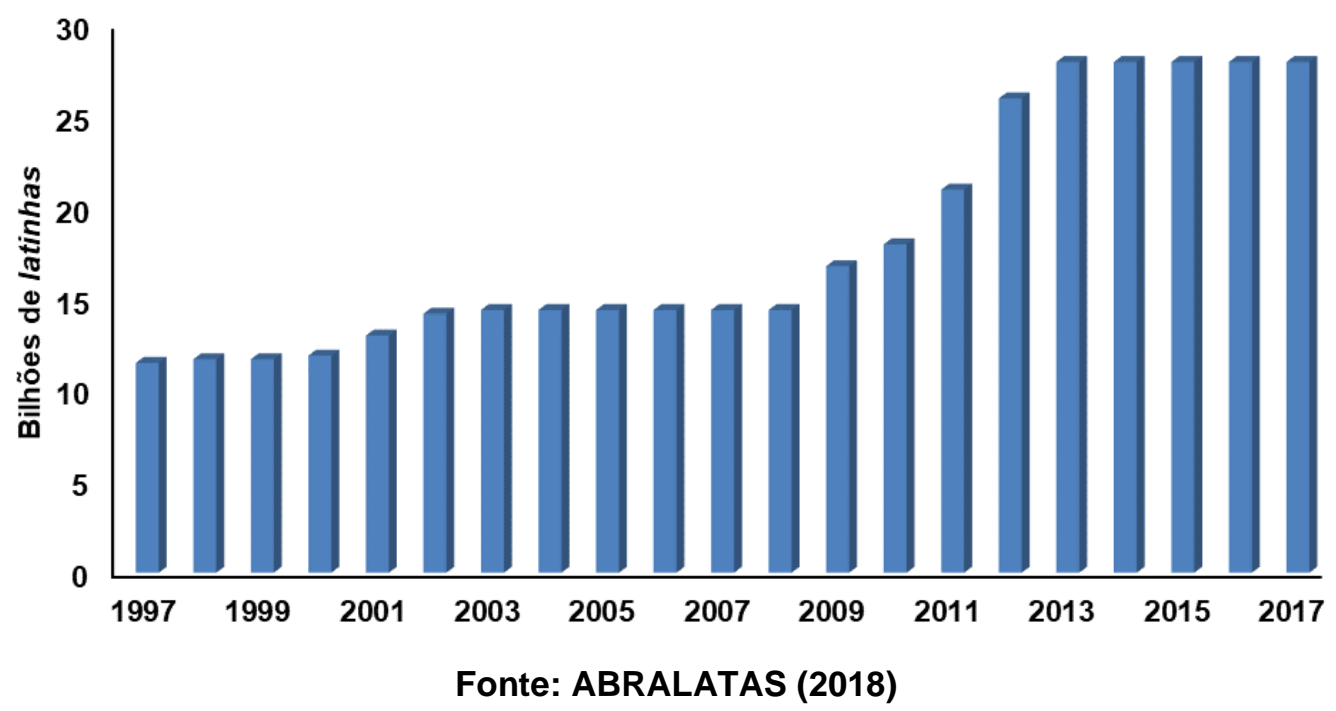

Ainda de acordo com a ABRALATAS (2018) o mercado brasileiro conta com 4 (quatro) fabricantes no mercado espalhados pelas cinco regiões geográficas brasileiras, com 18 fábricas 
produtoras de latinhas e seis unidades fabricantes de tampas, gerando capacidade produtiva de 28 bilhões de unidades, sendo assim o $3^{\circ}$ maior produtor mundial, atrás de Estados Unidos e China. $\mathrm{O}$ mercado brasileiro conta atualmente com a produção de 12 diferentes tamanhos de latinhas, desde $220 \mathrm{ml}$ até $710 \mathrm{ml}$, com o envase atual de cervejas, refrigerantes, chás, energéticos, sucos e cachaças.

O Brasil também se destaca na reciclagem das latinhas, encontrando-se na atualidade como líder mundial no índice de reaproveitamento das embalagens, conforme a Figura 16 mostra os dados históricos de reciclagem do setor. Verifica-se nos dados apresentados que o Brasil já alcançou estabilidade neste quesito, apresentando em média $97,1 \%$ na reciclagem das latinhas de Al entre 2008-2017, demonstrando assim consistência nos programas estabelecidos e também comprometimento em todos os setores envolvidos na iniciativa.

Figura 16 - Indicadores de reciclagem de latinhas de Al no Brasil

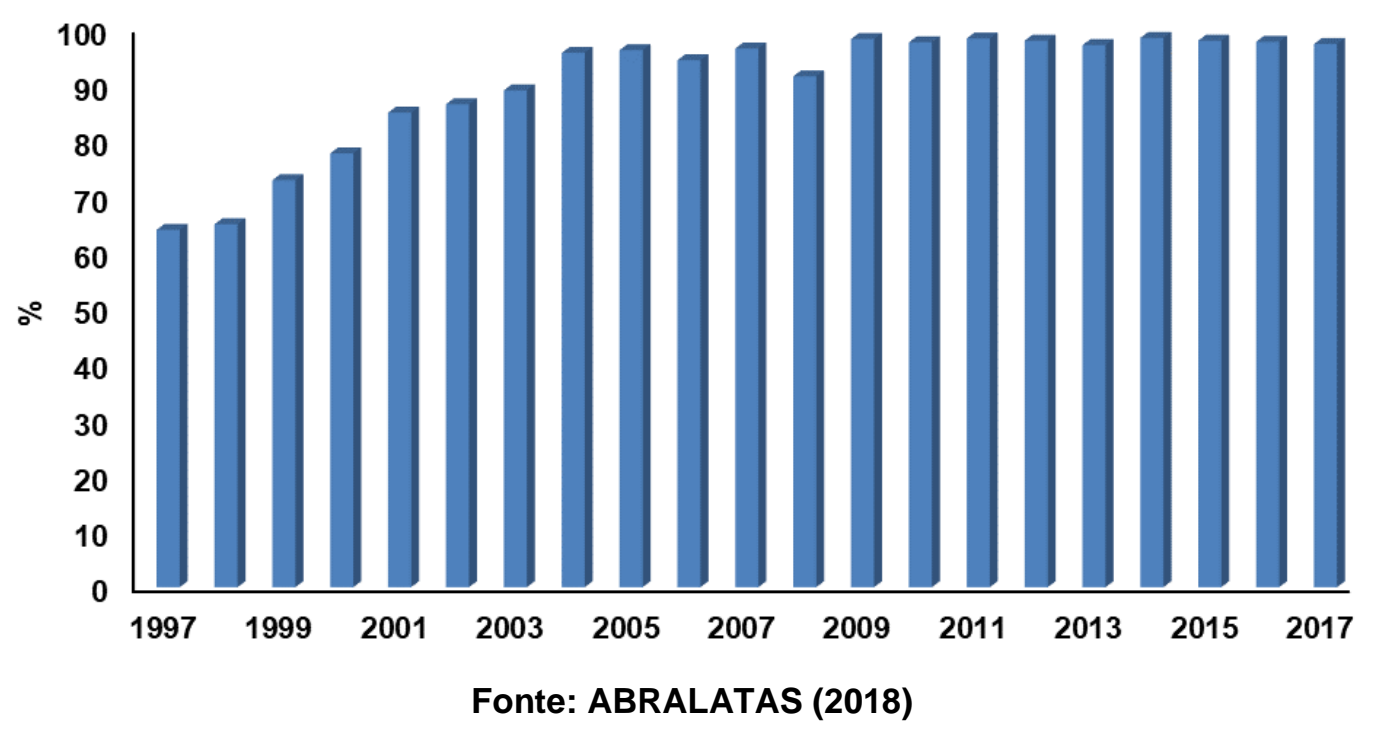

\section{PROCESSO PRODUTIVO DE LATINHAS DE ALUMÍNIO}

Visando possibilitar estudos de otimização do processo de produção de latinhas de Al, o qual já é tecnologicamente muito avançado, vem a ser útil a obtenção da máxima informação possível sobre os materiais e métodos envolvidos (FOLLE et al., 2008). Os insumos utilizados na fabricação de latinhas são (CAN MANUFACTURING INSTITUTE, 2018):

- Alumínio: Al de liga metálica 3104 e tempera $\mathrm{H} 19$, fornecido em forma de bobinas que pesam de 10 a 13 ton. A chapa é fornecida com uma camada de lubrificação, chamada de prélubrificação. A liga metálica contém $0,8-1,3 \%$ de $\mathrm{Mg}, 0,8-1,4 \%$ de $\mathrm{Mn}, 0,8 \%$ de $\mathrm{Fe}, 0,6 \%$ de $\mathrm{Si}$ e $0,05-0,25 \%$ de $\mathrm{Cu}$ (AA, 2009); 
— $\underline{\text { Tinta: }}$ a tinta empregada é produzida à base d'água, elaboradas a partir de pigmentos ou corantes;

- Verniz interno: o verniz interno empregado também é produzido à base d'água, fabricado a partir de polímeros específicos para esta aplicação;

- Verniz externo: o verniz externo empregado é produzido à base de epóxi e água. O verniz é fornecido com alta viscosidade e é diluído para o uso. O verniz comum é denominado como verniz brilho, porém existem também vernizes especiais como o fosco e o táctil.

A produção de latinhas de $\mathrm{Al}$ é dividida em duas etapas, cada uma em um setor, os quais são denominados Front End e Back End. O primeiro setor, Front End, é o responsável pela construção do corpo da latinha e sua lavagem; enquanto que o segundo é responsável pela impressão do rótulo, aplicação de verniz interno, formação do pescoço e embalagem em pallets. As latinhas são fabricadas de forma a resistir uma pressão interna de 0,62 MPa e podem suportar pressão de até $133 \mathrm{kgf}$. (SOUZA, 2002).

Os dois setores do processo produtivo de latinhas utilizam-se de Transportadores, os quais possuem como principal função o transporte do produto entre uma etapa do processo e a outra. São utilizadas esteiras mecânicas acopladas à motores elétricos e também mesas de ar conectadas a blowers em alguns segmentos da fábrica.

As etapas do processo de fabricação de latinhas de Al são descritas a seguir (CAN MANUFACTURING INSTITUTE, 2018; ABRALATAS, 2018):

\section{FORMAÇÃO DO COPO}

No primeiro processo da fábrica, a chapa de Al em bobina é desbobinada por um mandril e inicialmente lubrificada para entrada em uma máquina denominada Cupper (de modo que esta etapa é denominada: Cupper) que consiste de uma prensa vertical de dupla ação, responsável pelo corte do disco e estampagem em forma de copo. Este copo é retirado da prensa por transportadores acionados à ar e levado até o segundo piso da fábrica, via elevador de esteira de vácuo, onde adentra em outro transportador de mesa à ar, que é responsável por alimentar a próxima etapa do processo, as Bodymakers. A Figura 17 mostra a imagem do copo estampado na etapa Cupper. 


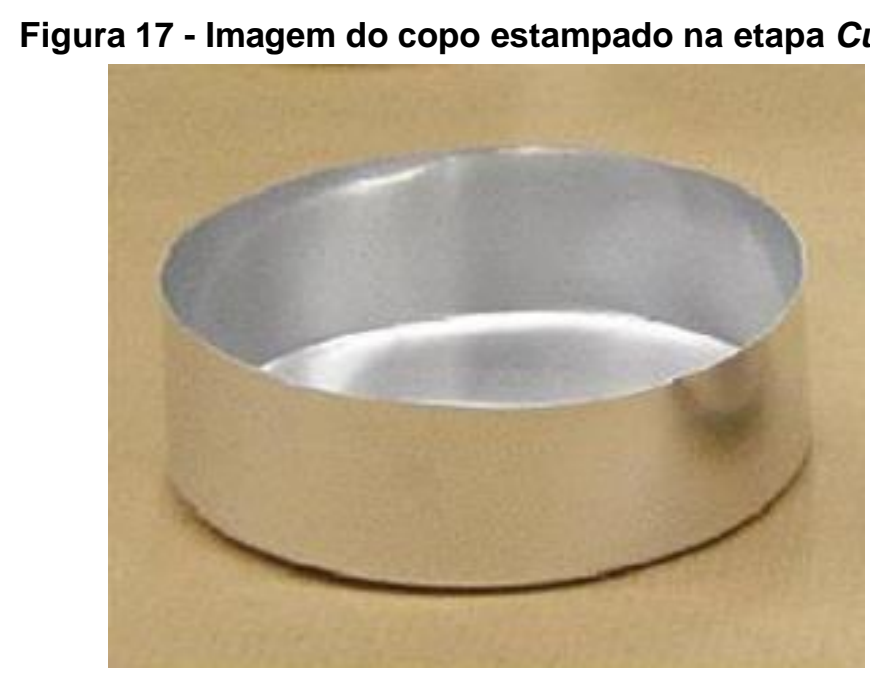

Fonte: Adaptado de Gee (2014)

\section{FORMAÇÃO DO CORPO}

A próxima etapa é a formação do corpo da latinha. Esta etapa do processo consiste na transformação de copos provenientes da etapa Cupper em corpo de latinhas. Os copos são alimentados em um equipamento denominado Bodymaker (de modo que esta etapa é denominada: Bodymaker) através de calhas, via efeito da gravidade devido ao fato de os copos se encontrarem no segundo piso e o equipamento no primeiro piso. O equipamento Bodymakers consiste de uma prensa horizontal, sendo responsável pela formação do corpo da latinha. O equipamento utiliza quatro 4 ferramentas progressivas. A primeira ferramenta realiza somente o redesenho da peça, sem reduzir a espessura do metal. As outras três ferramentas possuem função reduzir a espessura das paredes laterais, de modo forma a elevar a altura da peça. Por fim, o fundo da latinha é estampado em ferramenta pneumática. O equipamento é refrigerado por óleo solúvel, que flui em circuito fechado com sistema de filtros e possui sua viscosidade e temperatura controladas. A progressão no formato da latinha é mostrada pela Figura 18. 
Figura 18 - Progressão na estampagem e formação da parede da latinha

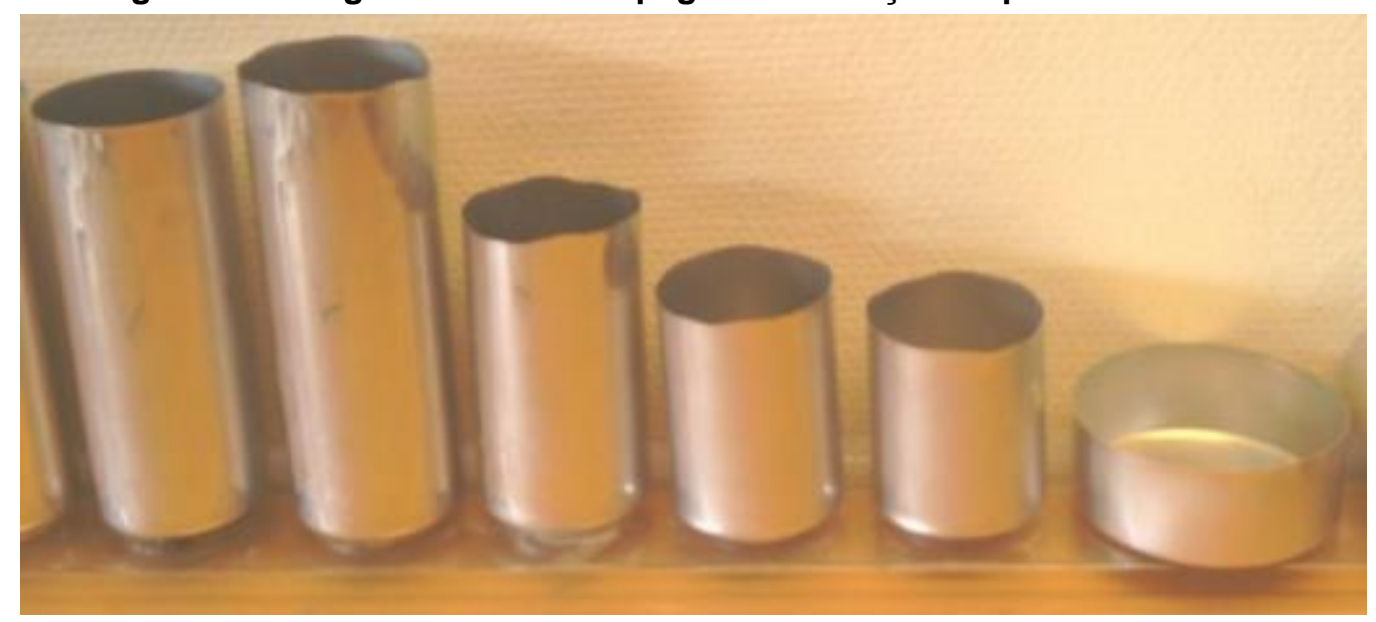

Nota: Da direita para esquerda: Copo, Redraw, 10 Iron, 20 Iron, 3이으 Iron e Trimmer Fonte: Adaptado de Eliasson e Modari (2014)

Após o estiramento, o fundo da embalagem é formado por uma ferramenta de estampagem pneumática. Com o corpo da latinha formado, esta segue para o dispositivo denominado Trimmer, que é acoplado ao equipamento responsável por aparar as rebarbas na borda superior da latinha, definindo assim a altura especificada do produto.

\section{LAVAGEM, SECAGEM E VERNIZ DE FUNDO}

Com o corpo da latinha formado, inicia-se a etapa de lavagem (denominada: Washer), feita em um equipamento constituído por sete estágios de lavagem, onde são retirados os resíduos orgânicos e inorgânicos da latinha. Utiliza como principais produtos químicos para lavagem o ácido sulfúrico e o ácido fluorídrico. Aplica também produto a base de flúor para proteção contra escurecimento e produto à base de tensoativos, para melhora da mobilidade (redução do coeficiente de atrito), melhorando o desempenho da latinha na linha e produção interna e também na linha de envase. Além da remoção das impurezas, a lavagem da latinha confere ao produto brilho e acabamento final para permitir uma boa aplicação da tinta e dos vernizes interno e externo. $O$ transporte das latinhas para dentro do equipamento é feito via esteira de aço, assim como no forno de secagem acoplado ao equipamento. $O$ controle dos parâmetros do equipamento é realizado por um controlador específico externo conectado a sensores de condutividade e $\mathrm{pH}$ presentes nos tanques (HENKEL, 2018). 


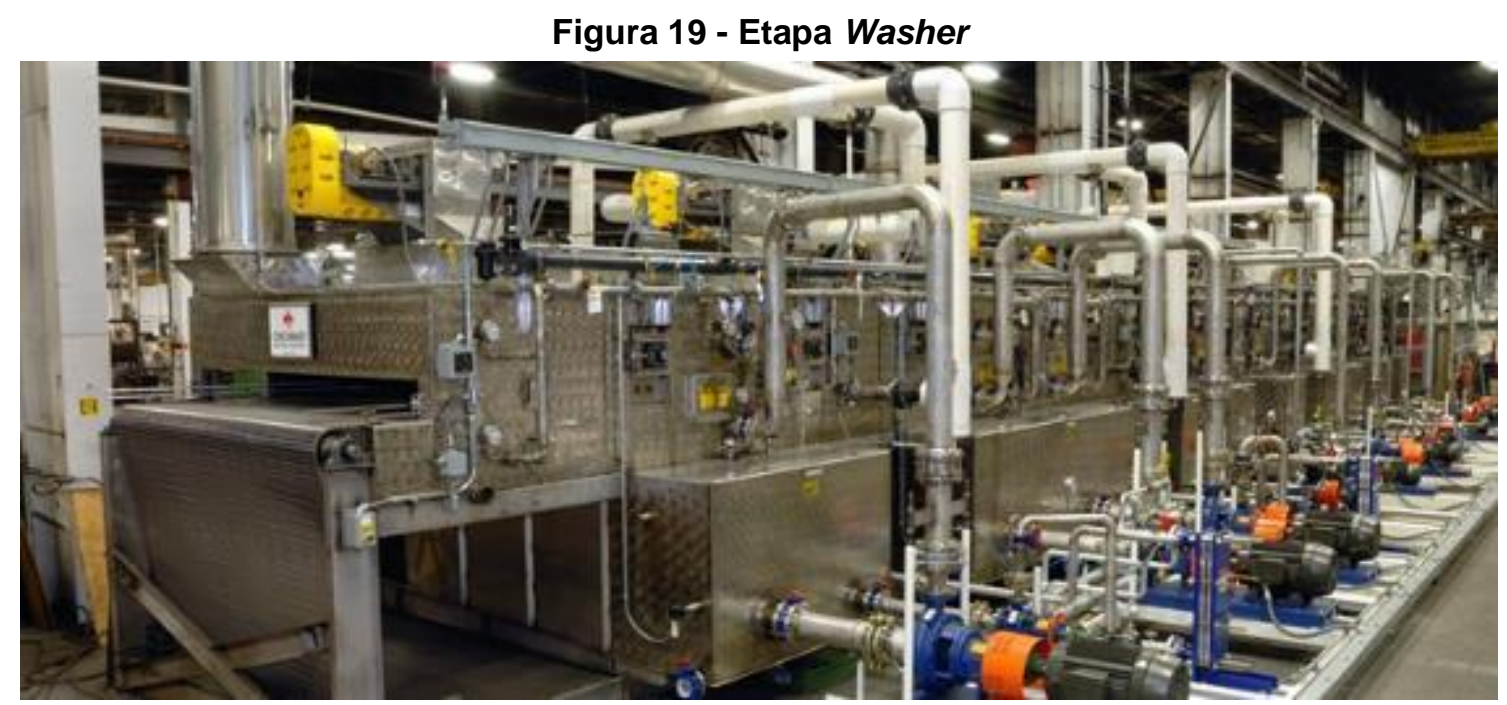

Fonte: Cincinatti Industrial Machinery (2018)

A aplicação de verniz na extremidade inferior exterior da latinha é feita por meio de um equipamento específico logo após sua secagem na Washer. A latinha, após ter o verniz aplicado por um rolo de borracha, segue para uma estufa com aplicação de luz ultravioleta (UV) para realizar a cura. O verniz serve para reduzir o coeficiente de atrito no domo da latinha, assim como para melhorar a performance do produto tanto na linha interna de produção, como também nas linhas de envase.

\section{IMPRESSÃO DO RÓTULO E APLICAÇÃO DE VERNIZ EXTERNO}

As etapas de rotulagem e aplicação de verniz externo são feitas por meio de um equipamento de impressão, tipo offset denominado: decoradora. A impressão, gerada por flexografia, pode ser realizada com até oito cores (SOUZA, 2002). As tintas utilizadas são produzidas em base água e a partir de corantes ou pigmentos. Após impressão do rótulo é aplicada uma camada de verniz externo, por meio de uma unidade envernizadora acoplada na máquina. Após isso, a latinha segue para um forno sendo transportada por uma corrente pinada, com objetivo de secagem da tinta e verniz. 
Figura 20 - Etapa de aplicação de rótulo e verniz externo - decoradora

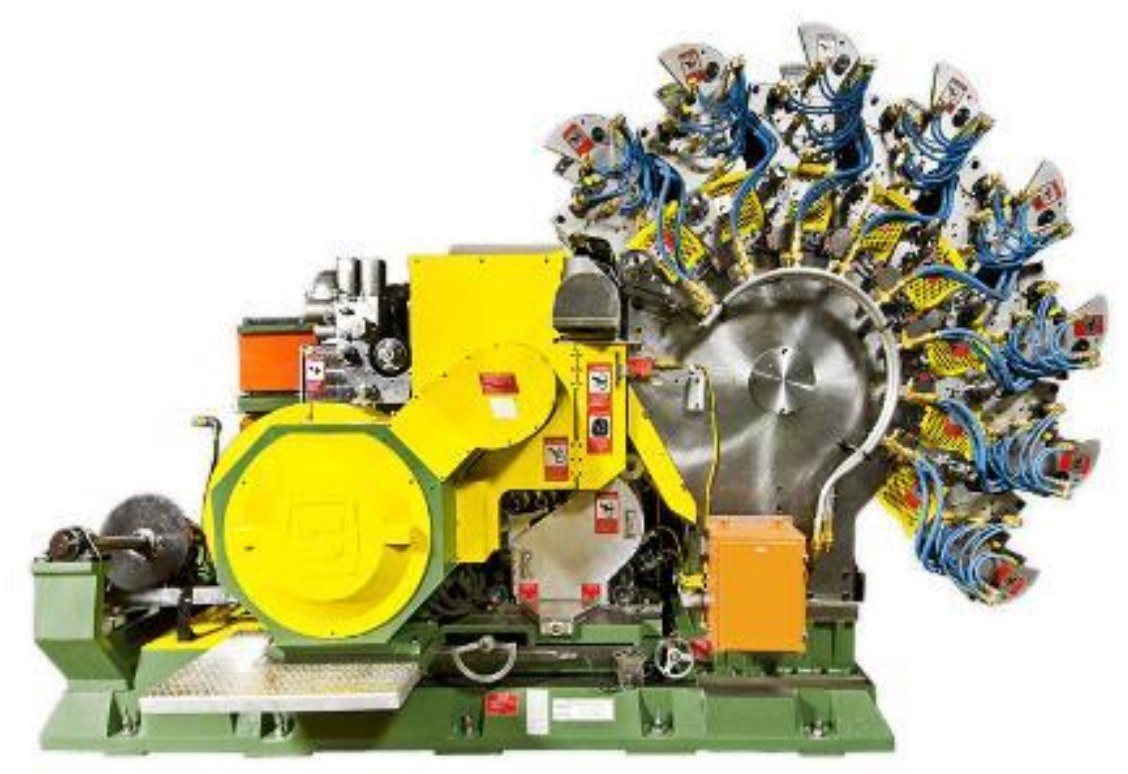

Fonte: Stolle Machinery (2018)

\section{APLICAÇÃO DO VERNIZ INTERNO}

Já com o rótulo e o verniz externo aplicado, a latinha segue para a aplicação de uma camada de verniz na parte interna, a qual é feita por meio de uma máquina denominada Lacquer Spray Machine (LSM). Esta camada de verniz tem a função de impedir o contato do produto com o Al, no sentido de evitar sua corrosão. A aplicação é realizada por duas pistolas pneumáticas, onde a primeira atua na parte inferior e domo da latinha e a segunda atua na parte superior do corpo da latinha. Alguns produtos envasados, com características mais corrosivas, como cachaça ou energético, necessitam de uma quantidade maior de verniz para garantir proteção (ABRALATAS, 2018). O verniz utilizado no processo é fabricado à base d'água e epóxi. As máquinas operam acopladas à um forno para cura do verniz, no qual as latinhas são transportadas via esteira de kevlar. 
Figura 21 - Aplicação de verniz interno - LSM

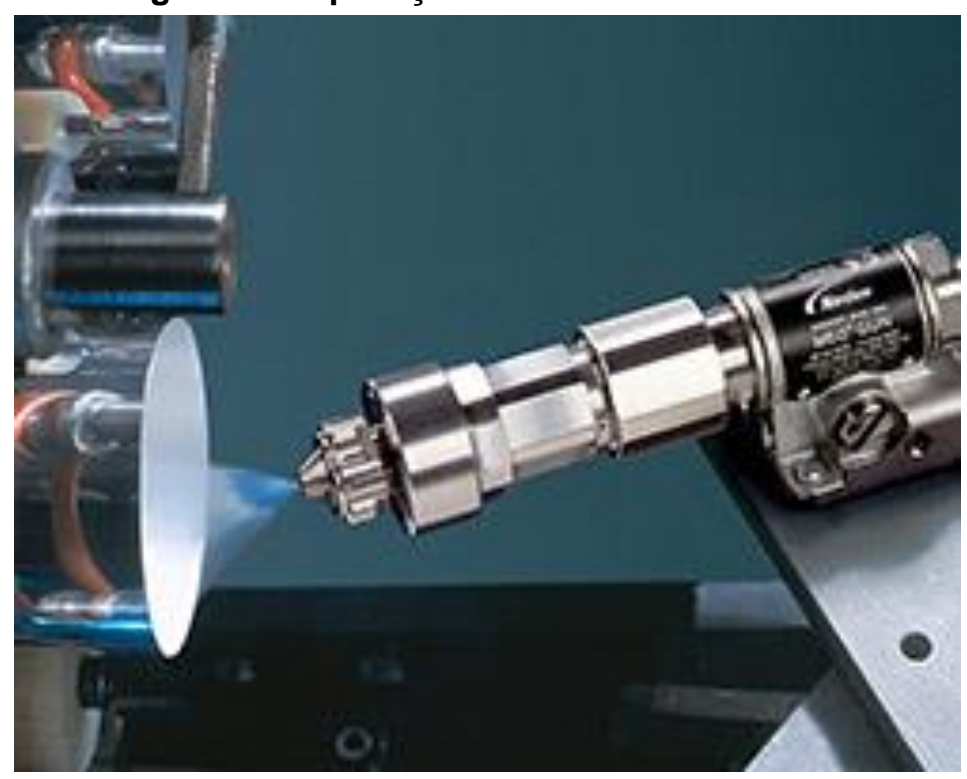

Fonte: Nordson (2018)

\section{FORMAÇÃO DO PESCOÇO, FLANGE E INSPEÇÃO FINAL}

A conformação do pescoço e formação do flange é feita por meio de um equipamento denominado Necker. A conformação do pescoço inicia com a aplicação de cera na área da parede superior da latinha, com a finalidade de proteger o ferramental da máquina contra riscos. A cera é aplicada por meio de feltro. O equipamento Necker possui 14 estações progressivas de conformação mecânica, de forma a reduzir o diâmetro superior da latinha, como demonstrado na Figura 22. Essa conformação confere a latinha o "pescoço", o qual é responsável por aumentar a resistência de coluna do produto e também possibilitar a aplicação de uma tampa menor, incidindo em menor custo e utilização de material (SOUZA, 2002). Após o pescoço ser formado, as latinhas passam pela estação flangeadora, que é responsável por moldar a borda superior, de forma a possibilitar o encaixe com a tampa após o envase. A Figura 22 mostra uma imagem do flange. Após o término, as latinhas são inspecionadas, com relação à possíveis orifícios de vazamento, por meio de uma estação de teste de luz de alta intensidade e por câmeras internas e externas, para retiradas de quaisquer outras imperfeições ou defeitos. 
Figura 22 - Progressão de conformação no equipamento Necker e moldagem da flange

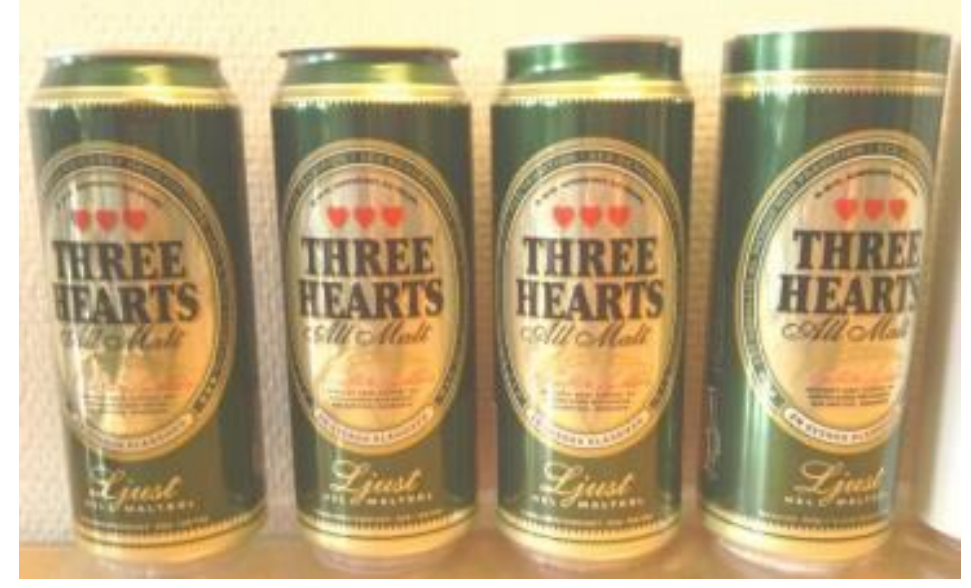

Fonte: Adaptado de Eliasson e Modari (2014)

\section{PALLETIZADORA E EMBALAGEM}

Nesta etapa, as latinhas prontas, são transportadas para um equipamento, que é responsável pela embalagem em pallets, separando as camadas com folhas separadoras plásticas ou de papelão. Após término do ciclo do equipamento, um quadro de topo é inserido na parte superior e o mesmo é embalado. O pallet é inspecionado pelo setor de qualidade e depois é retirado da linha por empilhadeiras e armazenado no estoque interno, até a saída para entrega, efetuada por modal rodoviário. 
Figura 23 - Imagem das latinhas de Al embaladas em um pallet

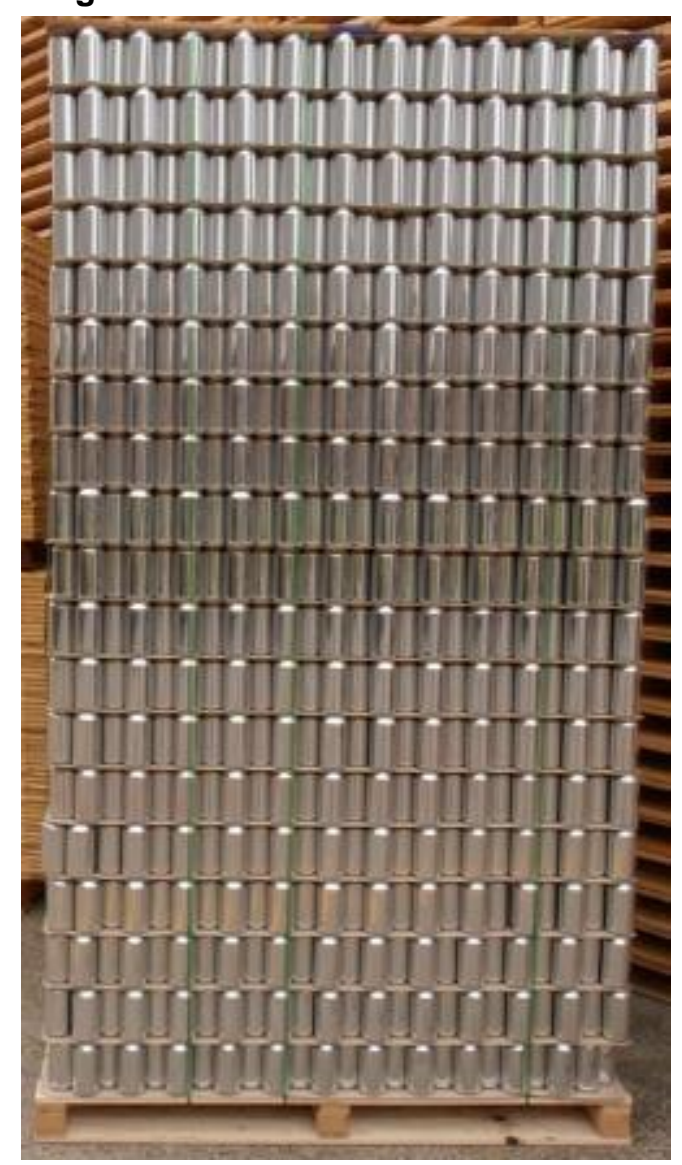

Fonte: Pace Pallets (2018)

\section{SETOR DE UTILIDADES}

O processo de produção de latinhas possui um setor de utilidades, o qual possui equipamentos destinados a fornecer insumos aos equipamentos das etapas de produção acima descritas. Os insumos fornecidos por cada equipamento do setor de utilidades e os equipamentos que fazem o uso dos mesmos são descritos abaixo:

1. Compressor: é responsável por fornecer ar para todos os equipamentos das etapas do processo produtivo, que operam e estão ligados à rede de ar comprimido, com destaque para os equipamentos Necker e Cupper, que são maiores consumidores de ar comprimido da planta;

2. Bomba de vácuo: é responsável por fornecer vácuo todos os equipamentos das etapas do processo produtivo, com destaque para a máquina decoradora e o equipamento Necker, que são principais usuários de vácuo da planta;

3. Filtro de óleo solúvel: é responsável por efetuar a filtragem, a correção de concentração e a temperatura do óleo refrigerante das máquinas Bodymakers. Este sistema realiza a 
filtragem com filtros do tipo manta, o aquecimento do óleo por resistência e o resfriamento via trocador de calor;

4. ETA/ETE: A Estação de Tratamento de Água (ETA) possui como função principal efetuar a coleta da água e seu tratamento para uso na planta. A estação possui sistema de osmose reversa, abrandador e deionizador. A outra unidade, a Estação de Tratamento de Efluentes (ETE) é responsável pelo tratamento dos efluentes gerados pela fábrica após o uso dessa água. O principal consumidor da ETA e fornecedor da ETE é a máquina Washer;

5. Scrap System:é um sistema destinado a coleta de resíduos de Al do processo, sejam eles na forma de retalhos gerados no processo durante operação da máquina Cupper e das máquinas Bodymakers, como também de coletar todo o desperdício que o processo gera; 


\section{METODOLOGIA}

O presente trabalho tem por objetivo geral empregar a ACVE para quantificar o consumo energético de uma planta de fabricação de embalagens metálicas para bebidas.

O método utilizado nesta pesquisa é o estudo de caso, o qual segundo Yin (2015) define-se como uma investigação empírica voltada a um fenômeno contemporâneo dentro de seu contexto da vida real. De acordo com Turrioni e Mello (2012) o estudo de caso objetiva disponibilizar amplo e detalhado conhecimento sobre um ou poucos objetos. Para isso, o método demanda estudo profundo e exaustivo dos mesmos.

O método de estudo de caso possui aplicações variadas. No entanto, destaca-se a grande utilidade que o mesmo tem em pesquisas exploratórias em que se enquadra o presente trabalho (VENTURA, 2007). A pesquisa exploratória visa proporcionar maior familiaridade com o problema abordado, de forma a demonstrá-lo de forma mais explícita. De acordo com Miguel (2007), a pesquisa exploratória se faz necessária quando a teoria não se encontra bem formulada na literatura ou ainda se encontra em fase emergente. Para tanto, o pesquisador deve possuir familiaridade com o objeto de estudo.

Quanto a sua natureza, a pesquisa classifica-se como Aplicada, de forma que objetiva gerar conhecimentos que possibilitem a resolução de problemas específicos (PRODANOV e FREITAS, 2013).

A Figura 24 mostra resumidamente o roteiro de desenvolvimento do presente trabalho: 
Figura 24 - Roteiro de pesquisa

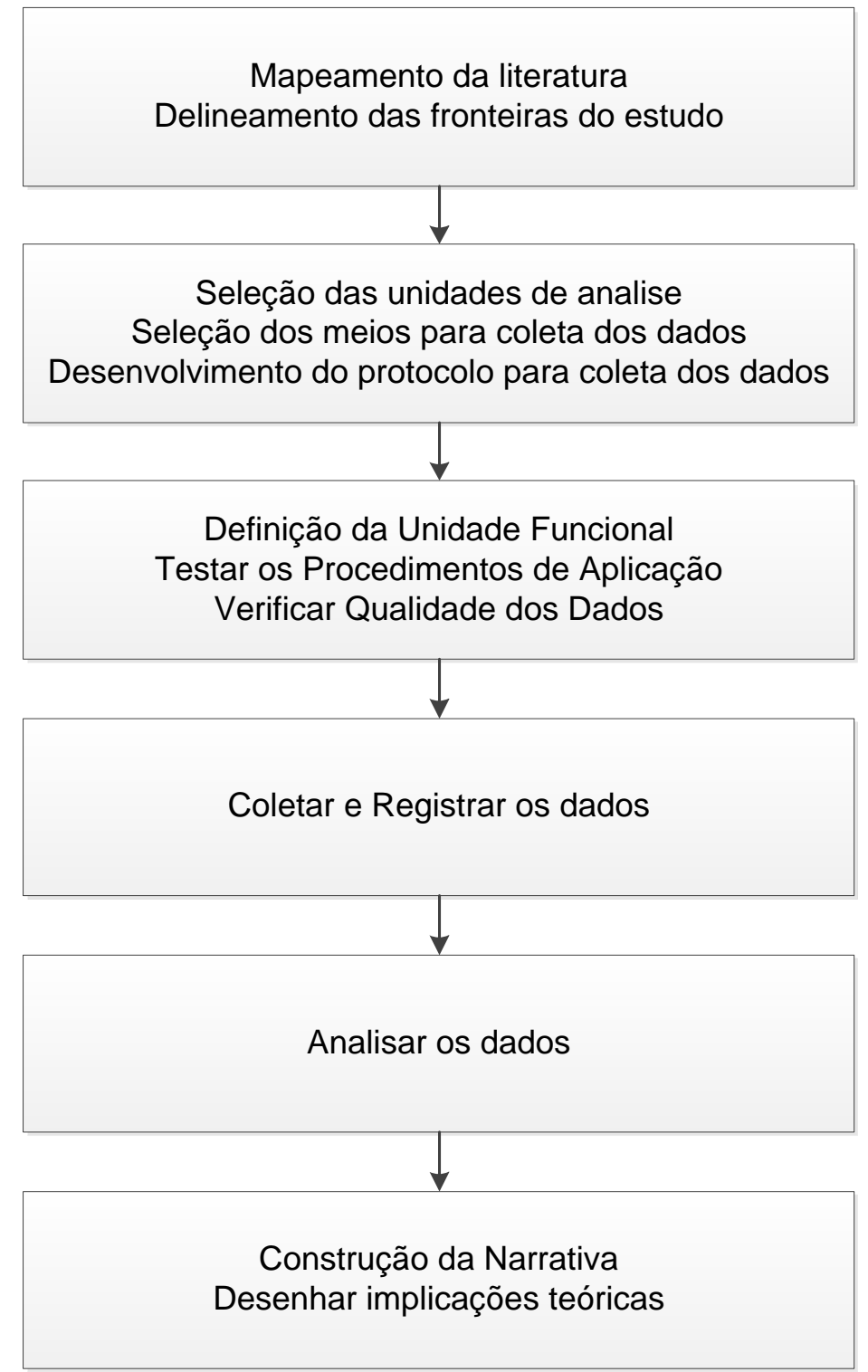

Fonte: Adaptado pelo autor de Miguel (2007)

Foi realizado o mapeamento da literatura utilizada no presente do trabalho através de pesquisas em periódicos, revistas, artigos científicos, teses, dissertações e livros que envolvem a fundamentação teórica para sustentação do objeto do estudo.

De forma a explorar a lacuna de pesquisa identificada, foi definido como fronteira do estudo o processo produtivo das latinhas de Al, não avaliando o consumo de energia predial e de áreas administrativas, assim como não se avalia no presente estudo o consumo de energia em etapas anteriores (Produção de Insumos) e posteriores (Envase e Reciclagem). O estudo avalia o consumo de energia por etapa do processo, por setor, por fonte de energia e finalmente o processo como um todo. A Figura 25 mostra de forma simplificada o processo de produção das latinhas de Al assim como a Fronteira de Pesquisa estabelecida para o estudo. 
Figura 25 - Cadeia simplificada do consumo de latinhas e fronteira de pesquisa

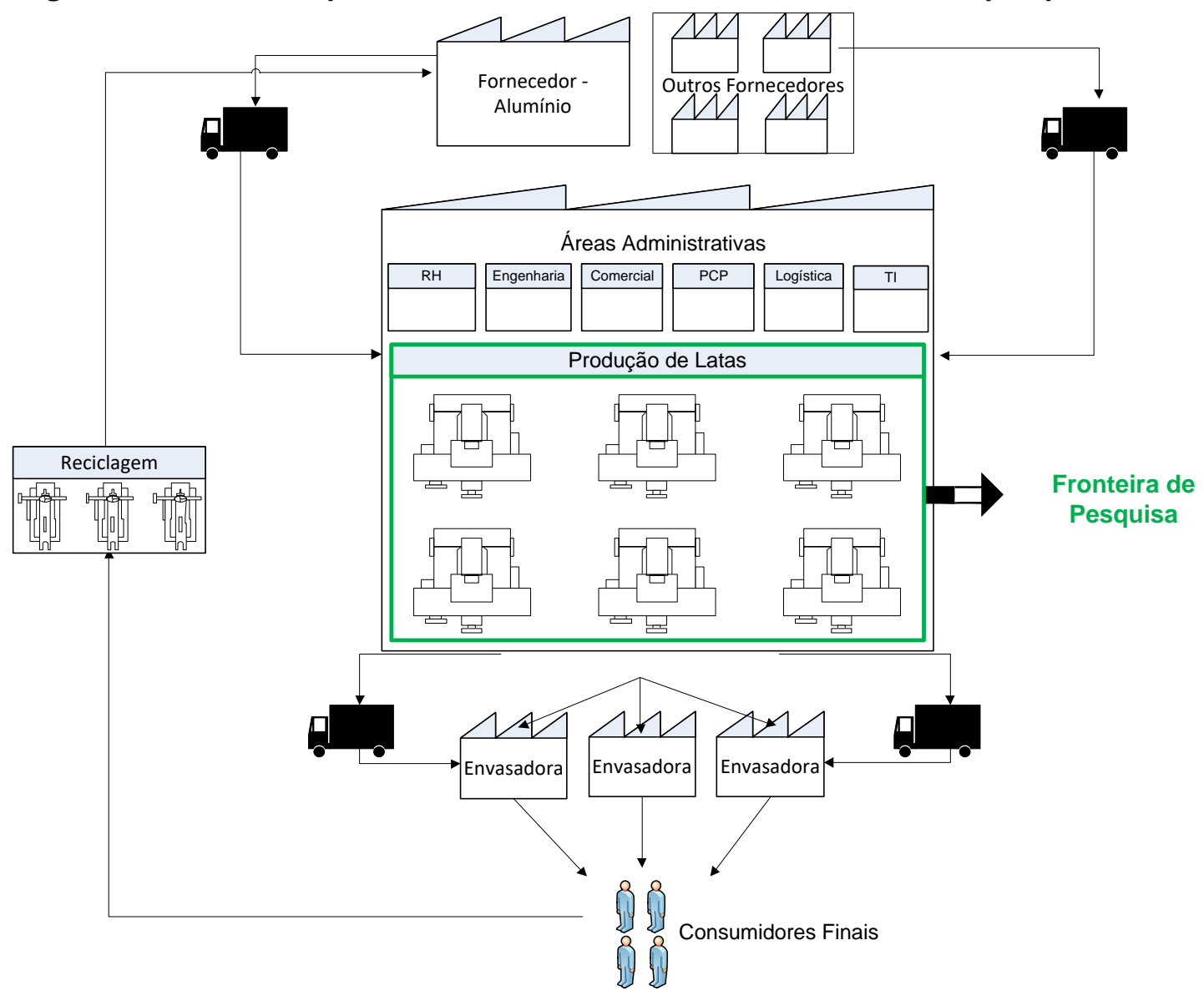

Fonte: Autoria própria

O estudo foi desenvolvido em uma planta produtora de latinhas de Al. Foi escolhida uma das linhas de produção da fábrica para condução do estudo, que apresenta construção recente e possui padrões de operação e comissionamento condizentes com o mercado internacional.

Os dados foram coletados diariamente durante o período de 30 dias ininterruptos. Durante esse período, a planta produtiva não sofreu nenhuma interrupção na produção proveniente de fatores externos (clima, desabastecimento de matéria prima, etc.) ou variação de demanda. O número de setups efetuados (trocas de rótulo) foi verificado como normal para o período quando comparado a dados gerenciais relativos a períodos similares da coleta de dados do estudo. Especialistas do setor de produção e de manutenção foram consultados para avaliação da melhor técnica disponível para coleta dos dados.

Durante o período da coleta dos dados, somente um produto foi produzido na linha de produção escolhida. A frequência de coleta dos dados foi definida como diária para que, através da média do período de 30 dias, venha a ser possível obter dados fidedignos à realidade da linha de 
produção, de forma que existem ligeiras oscilações de performance no processo, o qual opera com Overall Equipment Effectiveness (OEE) de aproximadamente 90\%.

Para obter-se uma coleta de dados eficiente e fidedigna, necessita-se a definição de um protocolo de dados, o qual deve nortear a condução do caso, por meio da definição das unidades de análise e de como os dados serão coletados (MIGUEL, 2007).

Os dados coletados, meios de coleta e recursos utilizados podem ser verificados no Quadro 2:

Quadro 2 - Protocolo de coleta de dados

\begin{tabular}{|l|l|l|l|l|}
\hline \multicolumn{2}{|c|}{ Atividade } & \multicolumn{1}{|c|}{ Meio de coleta } & \multicolumn{1}{|c|}{$\begin{array}{c}\text { Recursos } \\
\text { físicos }\end{array}$} & \multicolumn{1}{|c|}{$\begin{array}{l}\text { Recursos } \\
\text { humanos }\end{array}$} \\
\hline 1 & $\begin{array}{l}\text { Estudo dos } \\
\text { equipamentos da linha } \\
\text { de produção e } \\
\text { utilidades }\end{array}$ & $\begin{array}{l}\text { Visitas a linha de produção e } \\
\text { análise de documentos }\end{array}$ & $\begin{array}{l}\text { Desenhos da danta } \\
\text { elanta } \\
\text { manuais de } \\
\text { equipamentos }\end{array}$ & $\begin{array}{l}\text { Manutenção } \\
\text { elétrica/mecânica }\end{array}$ \\
\hline 2 & $\begin{array}{l}\text { Coleta do consumo de } \\
\text { energia }\end{array}$ & $\begin{array}{l}\text { Medição da corrente elétrica } \\
\text { no painel elétrico do } \\
\text { equipamento }\end{array}$ & $\begin{array}{l}\text { Amperímetro } \\
\text { "alicate" }\end{array}$ & $\begin{array}{l}\text { Manutenção } \\
\text { elétrica }\end{array}$ \\
\hline 3 & $\begin{array}{l}\text { Coleta do consumo de } \\
\text { gás natural }\end{array}$ & $\begin{array}{l}\text { Registros diários do valor do } \\
\text { Rotâmetro dos Fornos no } \\
\text { banco dados temporal do } \\
\text { sistema supervisório }\end{array}$ & $\begin{array}{l}\text { Sistema } \\
\text { supervisório }\end{array}$ & $\begin{array}{l}\text { Manutenção } \\
\text { elétrica }\end{array}$ \\
\hline $\begin{array}{l}\text { Coleta dos tempos de } \\
\text { produção e stand-by } \\
\text { por equipamento }\end{array}$ & $\begin{array}{l}\text { Relatório de eficiência diária } \\
\text { no sistema supervisório }\end{array}$ & $\begin{array}{l}\text { Sistema } \\
\text { supervisório }\end{array}$ & $\begin{array}{l}\text { Manutenção } \\
\text { elétrica }\end{array}$ \\
\hline 5 & $\begin{array}{l}\text { Coleta dos valores de } \\
\text { produção }\end{array}$ & $\begin{array}{l}\text { Registro no banco de dados } \\
\text { temporal do número total de } \\
\text { produção diário }\end{array}$ & $\begin{array}{l}\text { Sistema } \\
\text { supervisório }\end{array}$ & $\begin{array}{l}\text { Manutenção } \\
\text { elétrica }\end{array}$ \\
\hline
\end{tabular}

Fonte: Autoria própria

Para efetuar os cálculos de consumo de energia elétrica $(K W h)$ foi verificado a tensão $(V)$ no manual do equipamento e a corrente elétrica $(A)$ no painel elétrico principal em cada etapa do processo em duas diferentes ocasiões: equipamento em operação, quando o equipamento está em plena operação e equipamento em stand-by, o que pode significar equipamento aguardando comando do controle de linha para operar, manutenção ou ajuste. Essas duas medidas foram coletadas separadamente de forma a maximizar a fidelidade dos resultados, representando as duas possíveis condições do equipamento. Para possibilitar essa ação, foi também coletado no sistema supervisório, o tempo diário de operação do equipamento e o tempo em stand-by. Para ambos os casos foi utilizado a equação abaixo:

$$
\mathrm{E}=\left(\frac{(V \times I \times \sqrt{3})}{1000}\right) \times f p \times h
$$




\section{Em que:}

$\mathrm{E}=$ Energia em $\mathrm{kWh}$;

V = Tensão elétrica (Volts);

$I$ = Corrente elétrica $(A)$;

$\mathrm{fp}=$ Fator de potência;

$\mathrm{h}=$ Tempo de operação ou stand-by.

No sentido de manter as unidades no Sistema Internacional (SI), foi utilizado o fator de conversão $1 \mathrm{kWh}=3600 \mathrm{~kJ}$ (ANEEL, 2018).

Os dados de consumo de GN foram coletados nos medidores de fluxo (rotâmetros) instalados nas linhas de GN de cada máquina. Todos os medidores consultados e equipamentos utilizados durante a pesquisa estavam com calibração recente realizada por empresa especializada. Os dados foram coletados em metros cúbicos $\left(\mathrm{m}^{3}\right)$ e foram transformados para $\mathrm{kJ}$ utilizando o fator de conversão de $1 \mathrm{~m}^{3}$ de $\mathrm{GN}=39.348,400 \mathrm{~kJ}$ (COMGÁS, 2018).

Todos os dados coletados foram organizados em Planilha Microsoft Excel, onde foram organizados e hierarquizados, para assim poderem ser confrontados os dados de consumo de energia elétrica e térmica com os tempos de produção e posteriormente com a produção.

De acordo com Ferreira (2004) um estudo de ACV deve especificar claramente as funções do sistema a ser estudado. A Unidade Funcional (UF) vem a ser a medida do desempenho das saídas funcionais do sistema a ser estudado, a qual gera a referência para que as entradas e as saídas sejam relacionadas. Esta referência é necessária para assegurar a correta comparabilidade dos resultados, especialmente quando o estudo aborda sistemas diferentes.

O objetivo da UF é fornecer uma unidade de referência para que os dados de inventário sejam normalizados. A definição de UF depende do impacto ambiental, categoria do estudo e objetivos da pesquisa. A UF é frequentemente definida utilizando-se da massa do produto em estudo (ROY et al., 2009).

Sendo assim, de forma que o estudo aborda duas fontes de energia (elétrica e térmica) e sua relação com somente um produto, foi estabelecida a UF de kJ/1000 latinhas, referindo-se à quantidade de energia necessária para a produção de um milheiro de latinhas.

Foi verificado na planta preparação suficiente para sustentar o estudo, com painéis elétricos separados para cada equipamento do processo e também medidores de gás individuais em cada 
etapa utilizadora de energia térmica, dessa forma permitindo uma coleta sistemática e fidedigna dos dados necessários para desenvolvimento do presente estudo. O sistema supervisório, fornecedor dos dados

Após a consolidação dos dados, os mesmos vieram a ser confrontados com os dados de manuais de equipamento e também dados gerencias de consumo de energia da fábrica obtidos através das faturas de consumo de energia elétrica e GN, em função destes dados de consumo de energia por etapa de processo não possuírem comparação na literatura atual. Os dados de produção utilizados no estudo foram coletados de forma simples e eficiente devido a planta apresentar sistema supervisório estável com banco de dados temporal. 


\section{RESULTADOS E DISCUSSÕES}

\section{FLUXOGRAMA DO PROCESSO DE PRODUÇÃO DAS LATINHAS DE AL}

Inicialmente é apresentado o fluxograma simplificado do processo de produção das latinhas de $\mathrm{Al}$ (Figura 26) com as principais etapas que foram tomadas como base para o levantamento do consumo de energia elétrica e térmica, na forma de ACVE. No mesmo podem ser verificados quais energias cada etapa utiliza para seu funcionamento e também quais insumos são utilizados, perfazendo a conexão de cada etapa com o setor de utilidades.

As energias utilizadas no processo são a elétrica (Eletricidade) e a térmica (proveniente da queima de Gás Natural). Os insumos utilizados proveniente do setor de utilidades são ar comprimido (proveniente do compressor), vácuo (bomba de vácuo), óleo refrigerante (Filtro de Óleo Solúvel) e Água (ETE/ETA). Os outros insumos descritos no fluxograma e suas respectivas saídas não são abordados no presente estudo, o qual possui foco exclusivamente energético. 
Figura 26 - Fluxograma simplificado da produção de latinhas de Al

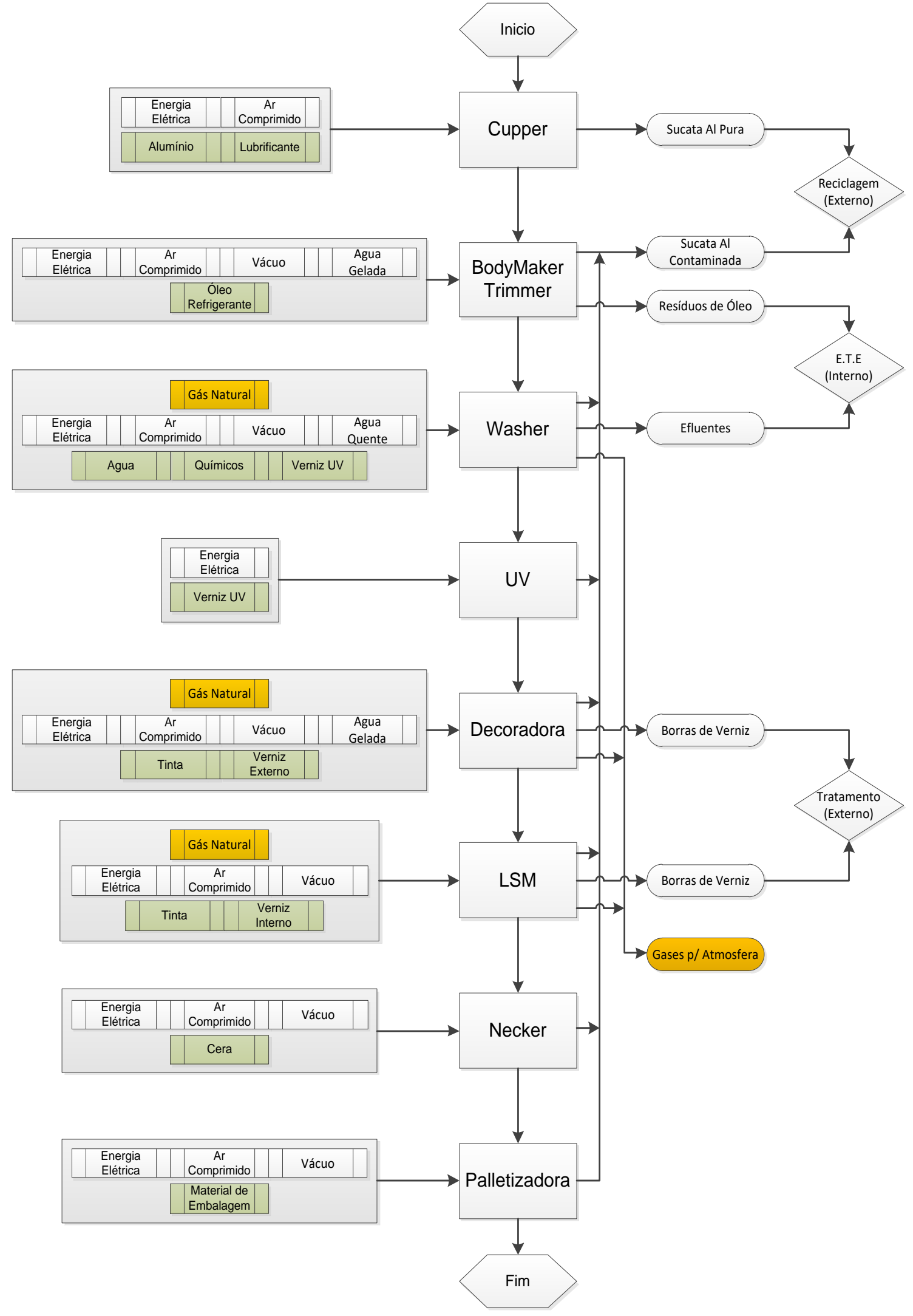

Fonte: Autoria própria 


\section{CONSUMO DE ENERGIA TÉRMICA}

A energia térmica, diferentemente da elétrica, não é utilizada em todas as etapas do processo. O primeiro processo na sequência a utilizar energia térmica é a máquina Washer. A utilização ocorre de duas formas: a primeira em um boiler destinado ao o aquecimento de três tanques sequenciais de lavagem do equipamento e na segunda forma o GN é utilizado no forno de secagem, que se encontra acoplado a máquina Washer, destinado a efetuar a secagem do produto após sua lavagem.

O uso de energia termica também ocorre na cura dos vernizes aplicados na latinha, nas partes interna e externa. Na sequência, o GN é usado no forno denominado Pin Oven, no qual as latinhas são transportadas via corrente pinada, após aplicação da tinta, do rótulo e do verniz externo. Após esta etapa, é feita a aplicação do verniz interno, utilizando-se para a cura do mesmo um equipamento denominado Internal Bake Oven (IBO) onde as latinhas são aquecidas através uma esteira de kevlar em temperatura próximas de $200^{\circ} \mathrm{C}$, necessária para secagem total.

A Tabela 4 apresenta o consumo de GN por etapa em energia (kJ) por 1000 latinhas. De outro modo, a Figura 27 mostra consumo proporcional de GN por etapa do processo.

Tabela 4 - Consumo de GN por etapa do processo de produção de latinhas de Al

\begin{tabular}{lc}
\hline \multicolumn{1}{c}{ Etapa do processo } & $\begin{array}{c}\text { Energia } \\
\text { kJ/1000 latinhas }\end{array}$ \\
\hline Boiler - Washer & $1.450,6$ \\
Forno - Washer & $12.765,1$ \\
Forno Pin Oven (verniz externo) & $11.604,7$ \\
Forno IBO (verniz interno) & $18.567,4$ \\
\hline \multicolumn{1}{c}{ TOTAL } & $\mathbf{4 4 . 3 8 7 , 8}$ \\
\hline
\end{tabular}

\section{Fonte: Autoria própria}

Figura 27 - Consumo de GN por etapa do processo (\%)

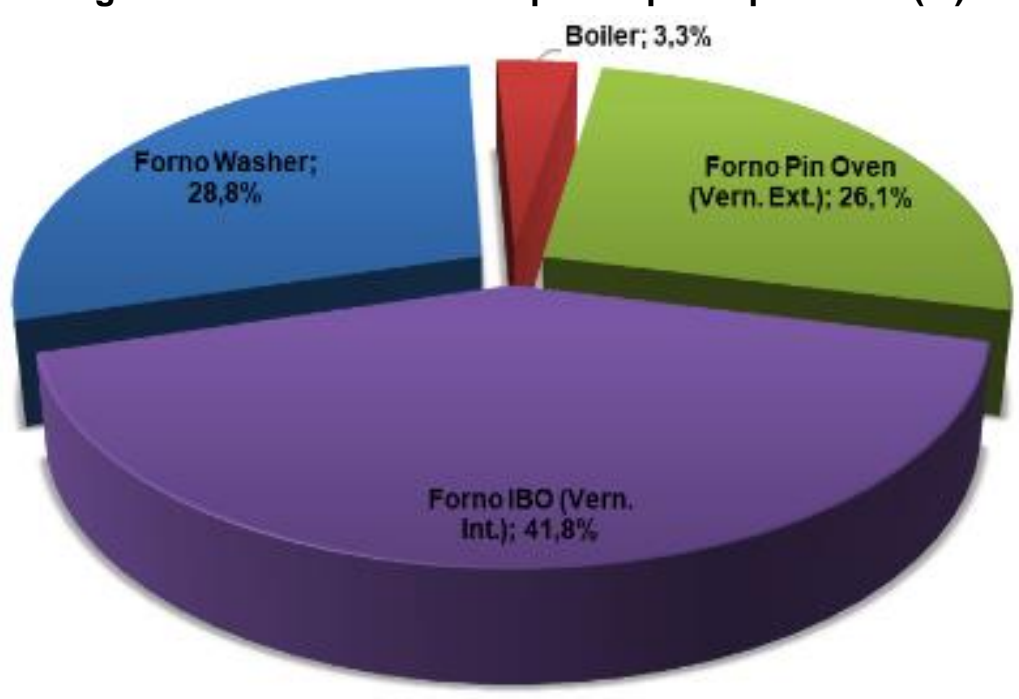

Fonte: Autoria própria 
Verifica-se com os resultados obtidos que o uso de GN tem maior participação nos fornos da linha de produção, os quais juntos somam $96,73 \%$ do consumo de energia térmica. O consumo do forno da máquina Washer foi similar ao consumo do forno de secagem do verniz interno. Por outro lado, o consumo mais elevado ocorreu no forno IBO, com $41,83 \%$ do consumo total de GN do processo.

Com relação à característica do funcionamento dos fornos empregados na fabricação das latinhas de Al destaca-se o forno IBO, que não possui modo de espera (stand-by), pois possui temperatura estável em todas as situações. Os outros fornos possuem temperatura de espera enquanto não estão sendo utilizados no processo, de modo que qualquer oscilação na temperatura dos fornos implica em um desarme completo do equipamento, o que se deve à criticidade que o mesmo tem no processo. Por ter função de curar o verniz interno, o qual tem por objetivo impedir o contato do $\mathrm{Al}$ com o produto envasado e assim prevenir qualquer tipo de corrosão e alteração de sabor, o mesmo possui uma amplitude bastante limitada para temperatura de trabalho.

\section{CONSUMO DE ENERGIA ELÉTRICA}

Os dados referentes ao consumo de energia elétrica do processo de produção de latinhas de Al foram levantados por meio da medição da carga em cada equipamento. Os dados por etapa do processo foram divididos em duas partes: uma referente ao consumo de eletricidade das principais máquinas (Tabela 5) e outra referente ao consumo de eletricidade dos equipamentos auxiliares do processo de produção (Tabela 6):

Tabela 5 - Consumo de energia elétrica pelas principais máquinas

\begin{tabular}{|c|c|c|c|}
\hline Máquina/etapa & $\mathrm{kJ} / 1000$ latinhas & $\begin{array}{l}\text { Consumo (\%) } \\
\text { com relação ao } \\
\text { consumo total de } \\
\text { eletricidade }\end{array}$ & $\begin{array}{l}\text { Consumo (\%) com } \\
\text { relação ao consumo de } \\
\text { eletricidade pelas } \\
\text { máquinas }\end{array}$ \\
\hline Cupper & $1.287,7$ & $2,1 \%$ & $5,1 \%$ \\
\hline Bodymakers & $11.275,8$ & $18,6 \%$ & $44,9 \%$ \\
\hline Washer & $5.150,7$ & $8,5 \%$ & $20,5 \%$ \\
\hline Decoradoras & $2.088,1$ & $3,4 \%$ & $8,3 \%$ \\
\hline Transportadores Front & $4.315,4$ & $7,1 \%$ & $12,1 \%$ \\
\hline Pin Ovens & $1.479,1$ & $2,4 \%$ & $5,9 \%$ \\
\hline LSMs & $1.426,9$ & $2,4 \%$ & $5,7 \%$ \\
\hline IBO & $1.252,9$ & $2,1 \%$ & $5,0 \%$ \\
\hline Necker & 904,8 & $1,5 \%$ & $3,6 \%$ \\
\hline Palletizadora & 243,6 & $0,4 \%$ & $1,0 \%$ \\
\hline Transportadores Back & $2.183,8$ & $3,6 \%$ & $6,1 \%$ \\
\hline Total & $31.608,7$ & $52,1 \%$ & $100,0 \%$ \\
\hline
\end{tabular}


Tabela 6 - Consumo de energia elétrica pelos equipamentos

\begin{tabular}{lccc}
\hline Equipamento Auxiliar & $\begin{array}{c}\text { kJ/1000 } \\
\text { latinhas }\end{array}$ & $\begin{array}{c}\text { Eletricidade } \\
\text { Total }\end{array}$ & $\begin{array}{c}\text { Eletricidade } \\
\text { Máquinas }\end{array}$ \\
\hline Filtro de óleo solúvel & $4.002,2$ & $6,6 \%$ & $11,3 \%$ \\
Compressor & $17.296,5$ & $28,5 \%$ & $48,7 \%$ \\
Bomba de vácuo & $3.201,8$ & $5,3 \%$ & $9,0 \%$ \\
ETE/ETA & $1.392,1$ & $2,3 \%$ & $3,9 \%$ \\
Scrap System & $3.132,2$ & $5,2 \%$ & $8,8 \%$ \\
\hline \multicolumn{1}{c}{ Total } & $\mathbf{2 9 . 0 2 4 , 7}$ & $\mathbf{4 7 , 9} \%$ & $\mathbf{1 0 0 , 0} \%$ \\
\hline \multicolumn{4}{c}{ Fonte: Autoria própria }
\end{tabular}

De acordo com os dados do consumo de energia elétrica, verifica-se que os equipamentos auxiliares são responsáveis pelo consumo de pouco menos da metade do consumo de energia, com 47,9\%. A maior parte deste percentual se deve ao consumo do compressor de ar comprimido, o qual fornece ar para todas as máquinas do processo de produção, especialmente ao Necker e a Cupper, que utilizam elevadas quantidades de ar comprimido no seu funcionamento.

Com relação ao consumo dos equipamentos auxiliares, usados para transporte nas diversas fases do processo de produção das latinhas (os transportadores da planta) destaca-se o consumo elevado dos transportadores do Front End e do Back End. O maior consumo de energia do setor Front End é devido ao fato de que os transportadores à ar exigem blowers de alta potência para funcionar, além de funcionamento constante. Em contrapartida, os transportadores mecânicos, operaram conforme o fluxo de latinhas na linha, parando e retornando ao funcionamento quando necessário.

Os dados de consumo de energia demonstram também um consumo de eletricidade mais elevado no setor do Front End, como mostra a Figura 28.

Figura 28 - Consumo de energia elétrica por setor (\%)

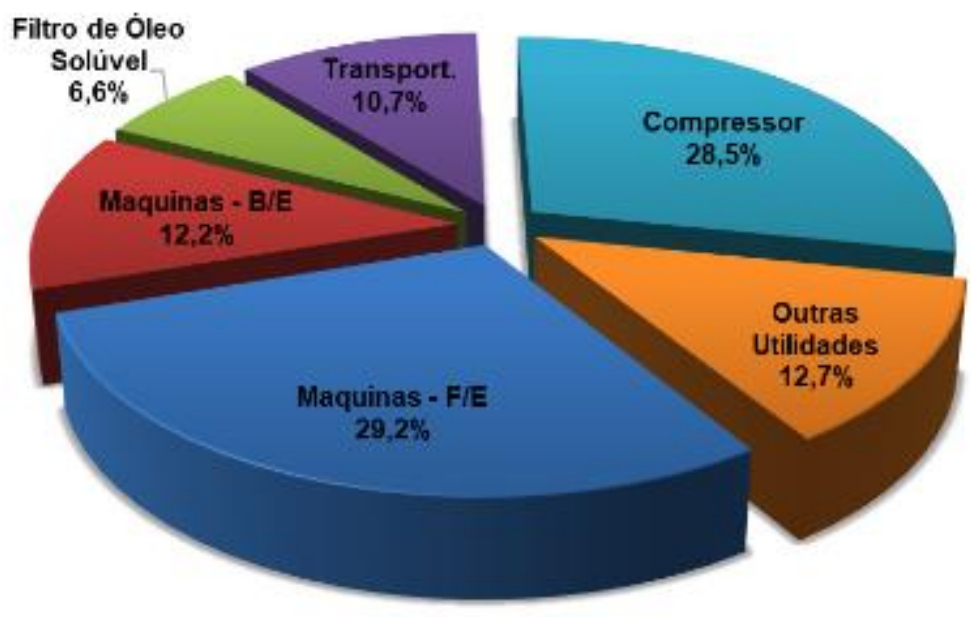

Fonte: Autoria própria 
O motivo do Front End ser mais intensivo no consumo de energia se deve ao fato do mesmo ser responsável pela fabricação do produto, com processos pesados de estampagem. O setor do Back End é responsável somente pela decoração, finalização e embalagem das latinhas, vindo dessa forma a consumir menos energia elétrica.

O filtro de óleo solúvel responde por $6,6 \%$ do consumo de energia elétrica do processo. 0 mesmo é destinado exclusivamente aos Bodymakers no Front End. Dessa forma, a Figura 29 mostra uma divisão do consumo dos processos Front End e Back End, levando em conta a divisão dos transportadores e também inclusão do filtro de óleo solúvel ao Front End. O cálculo não considera a divisão de gasto de energia elétrica dos compressores, bombas de vácuo, estação de tratamento de efluentes e Scrap System.

Figura 29 - Consumo de energia elétrica nos processos Back End e Front End (\%)

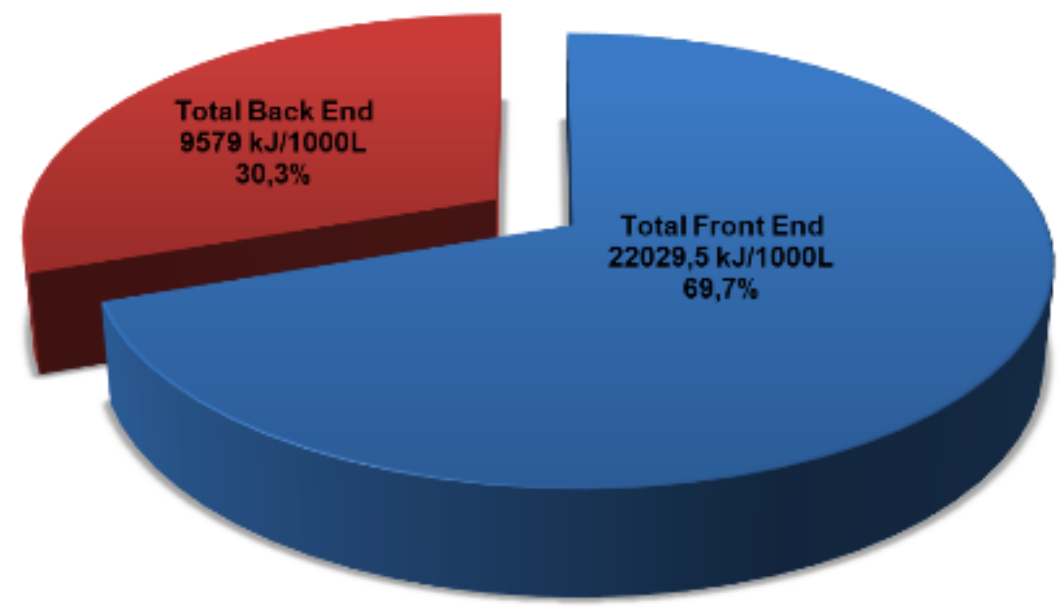

Fonte: Autoria própria

\section{CONSUMO DE ENERGIA TOTAL}

Os consumos de energia das duas fontes utilizadas no processo: energia elétrica e térmica são mostrados na Tabela 7, assim como o consumo total por etapa do processo é mostrado na figura 30, na forma de consolidação do consumo de energia do processo produtivo de latinhas:

Tabela 7 - Consumo total de energia na produção das latinhas de Al

\begin{tabular}{lcc}
\hline \multicolumn{1}{c}{ Fonte de energia } & kJ/1000 latinhas & Energia Total \\
\hline Energia Elétrica & $60.633,35$ & $57,7 \%$ \\
Energia Térmica (GN) & $44.387,79$ & $42,3 \%$ \\
\hline Consumo total & $\mathbf{1 0 5 . 0 2 1 , 1 4}$ & \\
\hline
\end{tabular}

Fonte: Autoria própria 
Figura 30 - Consumo de energia por etapa no processo produtivo (\%)

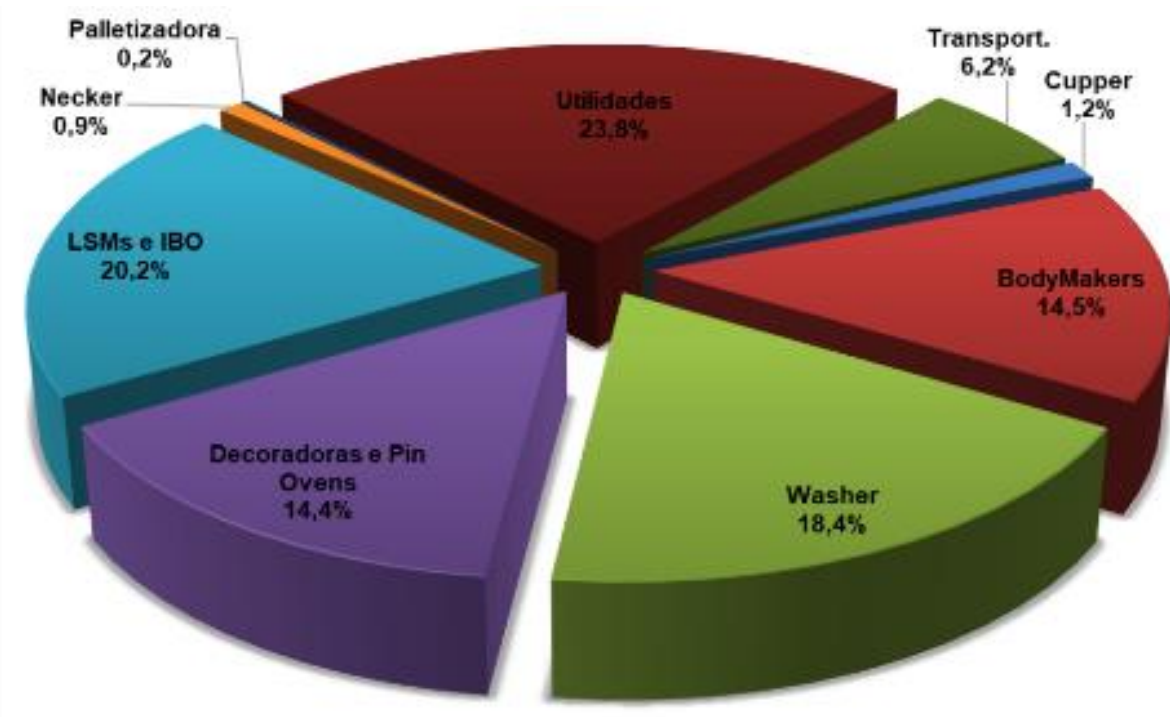

Fonte: Autoria própria

Desta forma, verifica-se que o balanço energético no processo de produção de latinhas de Al se apresenta como fonte predominante de energia a eletricidade. Porém, a energia térmica, apesar de somente ser aplicado em três etapas ao longo do processo, possui uma participação expressiva.

Com a consolidação dos consumos advindos das diferentes fontes de energia, o consumo total de energia por etapa do processo de produção das latinhas de Al é mostrado Figura 31. 
Figura 31 - Fluxograma energético da produção de latinhas de Al

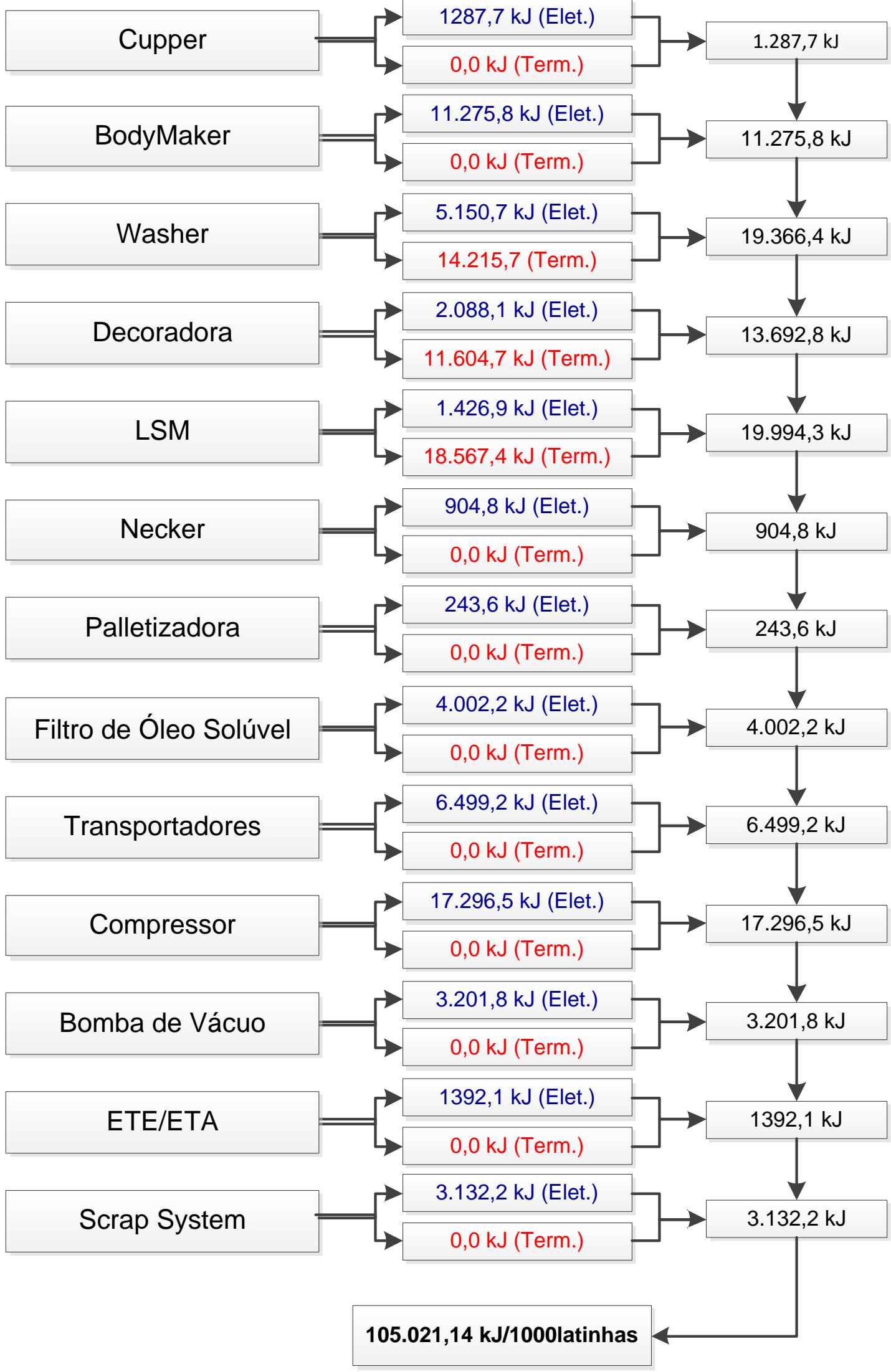

Fonte: Autoria própria 
Os resultados apresentados mostram que as etapas que utilizam GN em seus processos, somados, representam mais da metade do consumo da energia total do processo produtivo, com o total de 53,44\%. A importância do uso do GN está relacionada aos seguintes fatores: promover a secagem do produto, no sentido de proporcionar total assepsia das latinhas; conferir o acabamento apropriado ao produto após a lavagem; permitir aplicação da tinta e verniz externo e interno; além de conferir cura ao verniz externo e interno, protegendo o rótulo e garantindo a correta impermeabilização do alumínio com o produto.

Avaliando a criticidade dos processos que utilizam o GN na planta, não visualiza-se possíveis mudanças neste consumo. Atualmente, verifica-se que os diversos controles que os equipamentos possuem são em sua maioria voltados para a segurança e a estabilidade do processo, necessários para conferir qualidade ao produto.

O uso de equipamentos auxiliares, na forma de utilidades, demonstrou uma participação elevada no consumo de energia, tendo como principais consumidores o compressor e as bombas de vácuo.

Visando racionalização do uso desses equipamentos e considerando que todos os equipamentos da fábrica fazem uso de ar comprimido e vácuo, estudos devem ser conduzidos na forma de verificar possibilidades de redução do uso, como melhorias e manutenções específicas focadas na prevenção do desperdício dessas energias.

Além disso, destacam-se os setores que aparecem como menos intensivos no consumo de energia, como Palletizadora, Necker e Cupper também devem ser levados em consideração em possíveis estudos focados a redução de energia, visto que são grandes consumidores das utilidades da fábrica, como o compressor e as bombas de vácuo.

O setor de produção que apresentou maior consumo de energia elétrica foi o das Bodymakers, onde o corpo da latinha é formado em processo de estampagem, que emprega motores de elevada potência na fabricação. O filtro do óleo solúvel, responsável por fornecer óleo refrigerante às Bodymakers, possui aquecimento à base de resistência elétrica e filtragem através de mantas. Novas tecnologias já são empregadas no setor, com o uso de boilers aquecidos à GN para aquecimento e também a utilização de filtros menores e mais compactos, visando assim reduzir a pressão de bombeamento necessária.

O setor de transportadores também demonstrou ser considerável consumidor de energia no processo. A área apresenta grande facilidade para efetuar reduções significativas no consumo de energia, incluindo soluções de baixo investimento, como melhorias nos controles automatizados de 
linha, visando manter em operação somente os transportadores necessários no momento, evitando que os mesmos permaneçam em operação durante momentos desnecessários no cotidiano da produção.

Diante dos resultados apontados e também da quantidade de dados apresentados ao longo do estudo, foi elaborado um quadro-síntese (Figura 32), de forma a demonstrar de forma gráfica e sumarizada as implicações teóricas do presente estudo. 
Figura 32 - Quadro síntese do consumo energético da produção de latinhas de Al

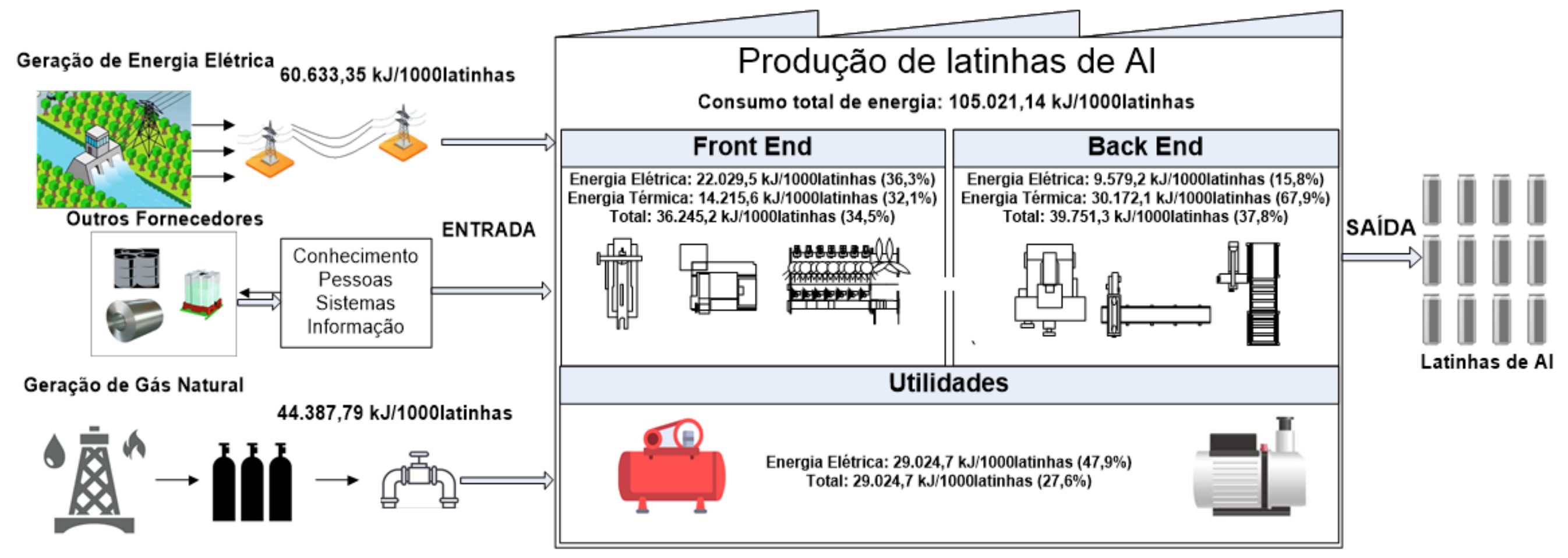

Fonte: Autoria própria 


\section{CONCLUSÕES}

Ao utilizar-se dos conceitos de ACVE, foi possível mapear o fluxo energético da produção das latinhas de Al, representando-o através de fluxogramas com a indicação quantitativa de consumo de energia por etapa do processo.

Em se tratando do método, a ACVE mostrou-se adequada para esta modalidade de analise energética, de forma a mostrar de forma clara o consumo de energia em cada etapa do processo produtivo, fronteira estabelecida para o estudo. O protocolo de pesquisa definido e o período de coleta dos dados foram fatores que proveram assertividade e confiabilidade aos resultados do estudo.

O processo produtivo de latinhas foi analisado em todos os equipamentos da linha de produção a fim de identificar os tipos de energia consumidos em cada etapa do processo produtivo (Energia Elétrica e Energia Térmica). O consumo energético por etapa do processo foi quantificado por coleta diária de dados de consumo de energia em cada equipamento.

Com a consolidação dos dados de consumo energético no processo produtivo, foi efetuado analise dos equipamentos e setores com maior consumo de energia. Verificou-se no balanço energético que o setor de utilidades da planta consome quantia significativa de energia, atingindo a marca de $23,8 \%$ da energia total da planta e $41,2 \%$ do total de energia elétrica. Ao estender a analise as maquinas do processo, evidencia-se diferença expressiva entre o consumo energético dos dois setores da fábrica. Em se tratando de energia elétrica, o setor do Front End demonstra um consumo mais elevado perante ao setor do Back End. No entanto, em se tratando de Energia Térmica, verificouse que o Back End possui consumo mais elevado em relação ao Front End.

O processo de produção de latinhas de alumínio possui no seu balanço energético uso expressivo de energia elétrica $(57,7)$, devido a característica dos maquinários existentes no processo, todos basicamente movidos a motores elétricos, inclusive no setor de utilidades da planta. Destacaram-se o compressor e o Filtro de Óleo Solúvel com $28,5 \%$ e 6,6\% do consumo total de Eletricidade, respectivamente. Para o compressor, atenção no processo deve ser dirigida para com vazamentos e utilização excessiva de ar comprimido. Para o caso do Filtro de Óleo Solúvel, a possibilidade de substituição do sistema de aquecimento por resistência elétrica para sistema de boiler deve ser analisada. 
Além disso, foi observado o consumo substancial de energia térmica no processo, que representa $42,3 \%$ da energia total empregada no processo de produção. Foi verificado a remota possibilidade na redução deste consumo, visto que a energia térmica é aplicada em setores críticos da fábrica, como a Washer e o IBO, que necessitam da estabilidade do processo, em função da criticidade de suas funções no processo, secagem das latas após banho químico e secagem do verniz interno, respectivamente.

Analisando o processo produtivo como um todo, verificou-se a necessidade de $105.021,14 \mathrm{~kJ}$ para a produção de 1000 latinhas. Desse montante, o setor do Back End veio a ser responsável por $37,8 \%$, seguido do Front End com $34,5 \%$ e do setor de Utilidades, com $27,6 \%$.

O estudo de caso adotou como fronteira de pesquisa o setor produtivo da fábrica. Dessa forma, estudos futuros podem vir a ser conduzidos em que se aborde a cadeia como um todo, envolvendo a fabricação das matérias primas das latinhas e também a sua destinação após fabricação, como envase, transporte e descarte. Como o presente estudo abordou somente a cadeia energética do processo, para fins de expansão do conhecimento acerca do mesmo, fazem-se necessários estudos futuros compreendendo outras matérias primas utilizadas no processo, como realização do balanço de massa envolvendo alumínio, vernizes e tinta, consumo de água e químicos, consumo de materiais de embalagem e geração de emissões de GEE, resíduos e efluentes. 


\section{REFERÊNCIAS}

AA (Aluminum Association). International alloy designations and chemical composition limits for wrought aluminum and wrought aluminum alloys. Arlington (EUA): Aluminum Association, 2009.

ABAL (Associação Brasileira do Alumínio). Estatísticas: nacionais: transformados. Disponível em: $<$ http://abal.org.br/\%20estatisticas/nacionais/transformados/consumo-domestico-por-setor $>$. Acesso em: 20 jan. 2018.

ABDELAZIZ, E. A., SAIDUR, R., MEKHILEF, S. A review on energy saving strategies in industrial sector. Renewable and Sustainable Energy Reviews, v. 15, p. 150-168, 2011.

ABNT (Associação Brasileira de Normas Técnicas). NBR ISO 14040: gestão ambiental: avaliação do ciclo de vida - princípios e estrutura. Rio de Janeiro: ABNT, 2001.

. NBR ISO 14041: gestão ambiental: avaliação do ciclo de vida - definição de objetivo e análise de inventário. Rio de Janeiro: ABNT, 2004.

NBR ISO 14042: gestão ambiental: avaliação do ciclo de vida - avaliação do impacto do ciclo de vida. Rio de Janeiro: ABNT, 2004.

NBR ISO 14043: gestão ambiental: avaliação do ciclo de vida - interpretação do ciclo de vida. Rio de Janeiro: ABNT, 2005.

ABRALATAS (Associação Brasileira dos Fabricantes de Latas de Alumínio). Lata de alumínio: conheça a latinha. Disponível em: <http://www.abralatas.org.br/\#containerLata>. Acesso em: 22 jan. 2018.

ABRE (Associação Brasileira de Embalagem). A embalagem. Disponível em: <http://www.abre.org.br/setor/apresentacao-do-setor/a-embalagem>. Acesso em: 26 jan. 2018.

ALMEIDA, C.; RODRIGUES, A.; BONILLA, S.; GIANNETTI, B. Emergy as a tool for ecodesign: evaluating materials selection for beverage packages in Brazil. Journal of Cleaner Production, v. 18, p. 32-43, 2010.

AMIENYO, D.; GUJBA, H.; STICHNOTHE, H.; AZAPAGIC, A. Life cycle environmental impacts of carbonated soft drinks. International Journal of Life Cycle Assessment, v. 18, p. 77-92, 2013.

ANEEL (Agência Nacional de Energia Elétrica). Fatores de conversão. Disponível em: $<$ http://www2.aneel.gov.br/arquivos/pdf/atlas fatores de conversao indice.pdf $>$. Acesso em: 10 maio 2018. 
ARENA, N.; SINCLAIR, P.; LEE, J.; CLIFT, R. Life cycle engineering of production, use and recovery of self-chilling beverage cans. Journal of Cleaner Production, v. 142, p. 1562-1570, 2017.

BAUXITE INDEX. Alumina production and trade: outlook. Disponível em: $<$ https://thebauxiteindex.com/en/cbix/industry-101/alumina-101/productiontrade/outlook\#alumina_101>. Acesso em: 10 nov. 2018.

BANOS, R.; MANZANO, F.; AGUGLIARO, F.; MONTOYA, F. G.; GIL, C.; ALCAYD, A.; GOMEZ, J. Optimization methods applied to renewable and sustainable energy: a review. Renewable \& Sustainable Energy Reviews, v. 15, p. 1753-1766, 2011.

BENTON, K.; YANG, X.; WANG, Z. Life cycle energy assessment of a stand-by diesel generator set. Journal of Cleaner Production, v. 149, p. 265-274, 2017.

BUNGARDEAN, C. M.; SOPORAN, V. F.; SALANTA, O. C. Considerations on the life cycle and recycling of aluminium beverage cans. Advances in Environmental Sciences, v. 5, p. 124, 2013.

CABEZA; L.F.; RINCON, L.; VILARIÑO, V.; PÉEREZ, G.; CASTELL, A. Life cycle assessment (LCA) and life cycle energy analysis (LCEA) of buildings and the building sector: a review. Renewable and Sustainable Energy Reviews, v. 29, p. 394-416, 2014.

CAI, Y.P.; HUANG, G.H.; YANG, Z.F.; TAN, Q. Identification of optimal strategies for energy management systems planning under multiple uncertainties. Applied Energy, v. 86, p. 480-495, 2009.

CAN MANUFACTURING INSTITUTE. How cans are made. Disponível em: http://www.cancentral.com/can-stats/how-cans-are-made. Acesso em: 17 out. 2018.

CARMINATTI JÚNIOR, R. Análise do ciclo de vida energético de projeto de habitações de interesse social concebido em light steel framing. 2012. 162 f. Dissertação (Mestrado em Construção Civil) Universidade de São Carlos, São Carlos (SP), 2012.

CERVIERI JÚNIOR, O.; JÚNIOR, J. R. T.; GALINARI, R.; RAWET, E. L.; SILVEIRA, C. T. J. O setor de bebidas no Brasil. BNDES Setorial, v. 40, p. 93-130, 2014.

CINCINATTI INDUSTRIAL MACHINERY. Can washers. Disponível em: $<$ http://www.canwash.com/can-washers/>. Acesso em: 3 ago. 2018.

CHAU, C. K.; LEUNG, T. M.; NG, W. Y. A review on life cycle assessment, life cycle energy assessment and life cycle carbon emissions assessment on buildings. Applied Energy, v. 143, p. 395-413, 2015.

COLTRO, L. (Org.); Avaliação do ciclo de vida como instrumento de gestão. Campinas (SP): CETEA/ITAL, 2007.

COMGÁS (Companhia de Gás de São Paulo). Tarifas do gás natural canalizado. Disponível em: $<$ https://www.comgas.com.br/tarifas >. Acesso em: 10 mar. 2018.

CORTEZ, A. T. C. Embalagens: o que fazer com elas? Rio Claro (SP): Viena, 2011. 
CURRAN, M. A. Life cycle assessment: principles and practice. Cincinnati (EUA): Environmental Protection Agency; National Risk Management Research Laboratory, 2006.

DETZEL, A.; MÖNCKERT, J.; Environmental evaluation of aluminium cans for beverages in the German context. The International Journal of Life Cycle Assessment, v. 14, p. 70-79, 2009.

DO, T. T. H.; SCHNITZER, H.; LE, T. H. A decision support framework considering sustainability for the selection of thermal food processes. Journal of Cleaner Production, v. 78, p. 112-120, 2014.

DOTY, S.; TURNER, W. C. Energy management handbook. 7. ed. Georgia (EUA): Fairmont Press, 2009.

EAA (European Aluminium). Aluminium used in packaging. Disponível em: <http://europeanaluminium.eu/about-aluminium/aluminium-in-use/packaging $>$. Acesso em: 8 out. 2018.

EKVALL, T.; PERSON, L.; RYBERG, A.; WIDHEDEN, J.; FREES, N.; NIELSEN, P.; WESNAS, M. S. Life cycle assessment on packaging systems for beer and soft drinks (Environmental Project 399).

The Danish Environmental Protection Agency, Ministry of Environment and Energy, Denmark. 1998

ELIASSON, E.; MODARI, T. Efficiency analysis in highly automated mass production. Thesis (Master in Mechanical Engineering) - Department of Mechanical Engineering. Lund Institute of Technology, Lund (Sweden), 2014.

EPE (Empresa de Pesquisa Energética). Balanço Energético Nacional - 2017. Disponível em: $<$ https://ben.epe.gov.br/downloads/Relatorio Final BEN 2017.pdf $>$. Acesso em: 10 fev. 2018.

FAY, R.; TRELOAR, G.; IYER-RANIGA, U. Life-cycle energy analysis of buildings: a case. Building Research and Information, v. 28, p. 31-41, 2000.

FERREIRA, J. V. R.; Gestão ambiental: análise de ciclo de vida dos produtos. Viseu (Portugal): Instituto Politécnico de Viseu, 2004.

FOLLE, L. F., SILVEIRA NETTO, S. E.; SCHAEFFER, L. Analysis of the manufacturing process of beverage cans using aluminum alloy. Journal of Materials Processing Technology, v. 205, n. 1-3, p. 347-352, 2008.

FILION, Y. R.; MACLEAN, H. L.; KARNEY, B. W. Life-cycle energy analysis of a water distribution system. Journal of Infrastructure Systems, v. 10, p. 120-130, 2004.

FITCH, P. E.; COOPER, J. S. Life cycle energy analysis as a method for material selection. Journal of American Society of Mechanical Engineers, v. 126, p. 798-804, 2004.

GATTI, J. B.; QUIEROZ, G. C.; GARCIA, E. E. C. Recycling of aluminum can in terms of Life Cycle Inventory (LCl). International Journal of Life Cycle Assessment, v. 13, p. 219-225, 2008.

GEE, M. Surface engineering for increased durability and energy efficiency in extreme conditions. 2014. Disponível em: <http://www.npl.co.uk/upload/pdf/gee.pdf>. Acesso em: 3 ago. 2018. 
GHOSH, T.; CASHMAN, S.; SOCCI, E. SAUER, B. Life cycle assessment of PepsiCo USA beverage packaging. In: IAPRI WORLD PACKAGING CONFERENCE, 18., Proceedings... Tacoma (USA): IAPRI, 2012.

GOLDEMBERG, J., LUCON, O. Energia e meio ambiente no Brasil. Estudos Avançados, v. 21, p. 720, 2007.

GUINÉE, J. B.; REINOUT, H.; GJALT, H.; ZAMAGNI, A.; MASONI, P.; BUONAMICI, R.; EKVALL, T.; RYDBERG, T. Life Cycle Assessment: past, present, and future. Environmental Science \& Technology, v. 45, n. 1, p. 90-96, 2011.

HAES, H. A. U.; HEIJUNGS, R. Life-cycle assessment for energy analysis and management. Applied Energy, v. 84, p. 817-827, 2007.

HANNON, B. System energy and recycling: a study of the container industry. New York: American Society of Mechanical Engineers, 1972.

HAUSCHILD, M.; JESWIET, J.; ALTING, L. From life cycle assessment to sustainable production: status and perspectives. CIRP Annals - Manufacturing Technology, v. 54, n. 2, p. 1-21, 2005.

HENKEL. Metal packaging solutions. Disponível em: <http://dm.henkeldam.com/is/content/henkel/AT18018 RW BR MetalPackaging WEBpdf>. Acesso em: 27 set. 2018.

HOSFORD, W. F.; DUNCAN, J. L. The aluminum beverage can. Scientific American, v. 9, p. 48-53, 1994.

HUANG, C. C.; MA, H. W. A multidimensional environmental evaluation of packaging materials. Science of the Total Environment, v. 324, p. 161-172, 2004.

HUBERMANN, N.; PEARLMUTTER, D. A life-cycle energy analysis of building materials in the Negev desert. Energy and Buildings, v. 40, p. 837-848, 2008.

HUNT, R.; FRANKLIN, E. LCA: how it came about - personal reflections on the origin and the development of LCA in the USA. International Journal of Life Cycle Assessment, v. 1, p. 4-7, 1996.

IBICT (Instituto Brasileiro de Informação em Ciência e Tecnologia). Desenvolvimento sustentável e avaliação do ciclo de vida. Brasília: IBICT, 2014.

IEA (International Energy Agency). Energy efficiency 2018. IEA; OECD: Paris, 2018. IEA headline energy data 2017. IEA; OECD: Paris, 2017a. International energy outlook: executive summary 2017. IEA; OECD: Paris, 2017b. Key world energy statistics 2017. OECD/IEA: Paris, 2017c. 
ITOIZ, E.; GASOL, C.; OLIVER-SOLÀ, J.; SANZ, V. M.; RIERADEVALL, J.; DURANY, X. B.; Comparative LCA of container Deposit Scheme and Green Dot System for PET bottles, cans and beverage carton waste in Spain. Life Cycle Management, Berlim, 2011.

LIU, G.; MÜLLER, D. B. Addressing sustainability in the aluminum industry: a critical review of life cycle assessments. Journal of Cleaner Production, v. 35, p. 108-117, 2012.

MARECHAL, F.; FAVRAT, D.; JOCHEM, E. Energy in the perspective of the sustainable development: the 2000W society challenge. Resources, Conservation and Recycling, v. 44, p. 245262, 2005.

MAXWELL, D. B. S. Beer cans: a guide for the archeologist. Historical Archaeology, v. 27, n. 1, p. 95113, 1993.

MELLO, M. C. A.; NASCIMENTO, L. F. Produção mais limpa: um impulso para a inovação e a obtenção de vantagens competitivas. In: ENCONTRO NACIONAL DE ENGENHARIA DE PRODUÇÃO (ENEGEP), 22..., Anais... Curitiba, 2002.

MENZIES, G. F.; TURAN, S.; BANFILL, P. F. G. Life-Cycle Assessment and embodied energy: a review. Proceedings of the Institution of Civil Engineers, v. 160, p. 135-143, 2007.

MIGUEL, P. A. C. Estudo de caso na engenharia de produção: estruturação e recomendações para sua condução. Production, v. 17, n.1, p. 216-229, 2007.

MOURAD, A. L.; GARCIA, E. E. C.; VILHENA, A. Avaliação do Ciclo de Vida: princípios e aplicações. Campinas (SP): CETEA/CEMPRE, 2002.

NIERO, M.; HAUSCHILD, M. Z.; HOFFMEYER, S. B.; OLSEN, S. I. Combining eco-efficiency and eco-effectiveness for continuous loop beverage packaging systems: learnings from the Carlsberg Circular Community. Journal of Industrial Ecology, v. 21, n. 3, p. 742-753, 2017.

NEGRELLI, A. J.; HOFFMEYER, S. B.; OLSEN, S. I.; BIRKVED, M. Closing the loop for aluminum cans: life cycle assessment of progression in cradle-to-cradle certification levels. Journal of Cleaner Production, v. 126, p. 352-362, 2016.

OLSEN, S. I. Circular economy: to be or not to be in a closed product loop? A Life Cycle Assessment of aluminum cans with inclusion of alloying elements. Resources, Conservation and Recycling, v. 114, p. 18-31, 2016.

NORDSON. MEG ${ }^{\circledR}$ II Spray Gun. Disponível em: <http://www.nordson.com/en/divisions/industrialcoating-systems/products/applicators/meg-ii-spray-gun>. Acesso em: 3 ago. 2018.

PACE PALLETS. Amcor beverage cans. Disponível em: <https://pacepalletservices.com.au/wpcontent/uploads/2012/12/amcor block pallets >. Acesso em: 3 ago. 2018.

PAPONG, S.; MALAKUL, P. Life-cycle energy and environmental analysis of bioethanol production from cassava in Thailand. Bioresource Technology, v. 101, p. S112-S118, 2010. 
PARASKEVAS, D.; KELLENS, K.; DEWULF, W.; DUFLOU, J. R. Environmental modelling of aluminium recycling: a life cycle assessment tool for sustainable metal management. Journal of Cleaner Production, v. 105, p. 357-370, 2015.

KELLENS, K.; RENALDI, W.; DEWULF, W.; DUFLOU, J. R. Closed and open loop recycling of aluminium: a life cycle assessment perspective. In: GLOBAL CONFERENCE ON SUSTAINABLE MANUFACTURING: INNOVATIVE SOLUTIONS, 11., Proceedings... Berlim (GER), 2013. p. 305310.

PASQUALINO, J.; MENESES, M.; CASTELLS, F. The carbon footprint and energy consumption of beverage packaging selection and disposal. Journal of Food Engineering, v. 103, p. 357-365, 2011.

PE AMERICAS. Life cycle impact assessment of aluminum beverage cans. Washington (EUA): Aluminum Association, 2010.

PEDROSO, G. M. P. Avaliação do Ciclo de Vida Energético (ACVE) de sistemas de vedação de habitações. 2015. 226 f. Tese (Doutorado em Estruturas e Construção Civil) - Universidade de Brasília, Brasília (DF), 2015.

PETRECCA, G. Industrial energy management: principles and applications. Dordrecht (HOL): Kluwer Academic Publisher, 1993.

PRAJWAL, B.; MALI; H. S.; NAGAR, R. Life cycle energy assessment of a typical marble processing plant: life cycle energy assessment. International Journal of Social Ecology and Sustainable Development, v. 10, n. 1, 2018.

PRODANOV, C. C.; FREITAS, E. C. Metodologia do trabalho científico: métodos e técnicas da pesquisa e do trabalho acadêmico. 2. ed. Novo Hamburgo (RS): FEEVALE, 2013.

RAMESH, T.; PRAKASH, R.; SHUKLA, K. K. Life cycle energy analysis of buildings: an overview. Energy and Buildings, v. 42, n. 10, p. 1592-1600, 2010.

RAMOS, M. C. E. S. Implementação de motores de alto rendimento em uma indústria de alimentos: estudo de caso. 2005. 91 f. Dissertação (Mestrado em Energia) - Universidade de São Paulo, São Paulo, 2005.

REIS, L. B. Geração de energia elétrica. 2. ed. São Paulo: Manole; 2011.

REN21 (Renewable Energy Policy Network for the 21st Century). Energias renováveis 2016: relatório da situação mundial. Disponível em: <http://www.ren21.net/wpcontent/uploads/2016/11/REN21_GSR2016_KeyFindings_port_02.pdf . Acesso em: 20 jan. 2018.

ROY, P.; NEI, D.; ORIKASA, T.; XU, Q.; OKADOME, H.; NAKAMURA, N.; SHIINA, T. A review of Life Cycle Assessment (LCA) on some food products. Journal of Food Engineering, v. 90, p. 1-10, 2009.

RUDBERG, M.; WALDEMARSSON, M.; LIDESTAM, H. Strategic perspectives on energy management: a case study in the process industry. Applied Energy, v. 104, p. 487-496, 2013. 
SALEH, Y. Comparative life cycle assessment of beverages packages in Palestine. Journal of Cleaner Production, v. 131, p. 28-42, 2016.

SHAHBAZ, M.; ZAKARIA, M.; SHAHZAD, S. J. H.; MAHALIK, M. K. The energy consumption and economic growth Nexus in top ten energy-consuming countries: fresh evidence from using the quantile-on-quantile approach. Energy Economics, v. 71, p. 282-301, 2018.

SIMON, B.; BEN AMOR, M.; FOLDÉNYI, R. Life cycle impact assessment of beverage packaging systems: focus on the collection of post-consumer bottles. Journal of Cleaner Production, v. 112, p. 1-11, 2016.

SINGH, P.; GUNDIMEDA, H. Life Cycle Energy Analysis (LCEA) of cooking fuel sources used in India households. Energy and Environmental Engineering, v. 2, p. 20-30, 2014.

SONG, Y. S.; YOUN, J. R.; GUTOWSKI, T. G. Life cycle energy analysis of fiber-reinforced composites. Composites Part A, v. 40, p. 1257-1265, 2009.

SOUZA, V. Z. Otimização dos parâmetros de controle de um processo de fabricação de latas: uma abordagem 6 Sigma. 2002. 76 f. Dissertação (Mestrado em Engenharia de Produção) - Universidade Federal de Itajubá, Itajubá (MG), 2002.

STOLLE MACHINERY. Rutherford decorator and basecoater. Disponível em: $<$ https://www.stollemachinery.com/en/products/rutherford-decorator-and-basecoater>. Acesso em: 3 ago. 2018.

STOTZ, P. M.; NIERO, M.; BEY, N.; PARASKEVAS, D. Environmental screening of novel technologies to increase material circularity: a case study on aluminium cans. Resources, Conservation and Recycling, v. 127, p. 96-106, 2017.

TAVARES, S. F. Metodologia de análise do ciclo de vida energética de edificações residenciais brasileiras. 2006. 225 f. Tese (Doutorado em Engenharia Civil) - Universidade Federal de Santa Catarina, Florianópolis, 2006.

TURRIONI, J. B.; MELLO, C. Metodologia de pesquisa em engenharia de produção. Itajubá (MG): UNIFEI, 2012.

USEPA (United States Environmental Protection Agency). LCAccess - LCA 101. 2001. Disponível em: <https://nepis.epa.gov/Exe/ZyPDF.cgi/P1000L86.PDF?Dockey=P1000L86.PDF>. Acesso em: 15 maio 2018.

VALT, R. B. G. Análise do ciclo de vida de embalagens de pet, de alumínio e de vidro para refrigerantes no Brasil variando a taxa de reciclagem dos materiais. 2004. 193 f. Dissertação (Mestrado em Engenharia de Processos Térmicos e Químicos) - Universidade Federal do Paraná, Curitiba, 2004.

VAN DER HARST, E.; POTTING, J.; KROEZE, C. Comparison of different methods to include recycling in LCAs of aluminium cans and disposable polystyrene cups. Waste Management, v. 48, p. 565-583, 2016. 
VENTURA, M. M. O estudo de caso como modalidade de pesquisa. Revista SOCERJ, v. 20, p. 383386, 2007.

WORRELL, E.; BERKEL, R. V.; FENGQI, Z.; MENKE, C.; SCHAEFFER, R.; WILLIAMS, R. O.

Technology transfer of energy efficient technologies in industry: a review of trends and policy issues. Energy Policy, v. 29, p. 29-43, 2001.

YIN, R. K. Estudo de caso: planejamento e métodos. Bookman, 2015. 


\section{SOBRE OS AUTORES}

\section{AURÉLIO KOVALESKI}

Mestre em Engenharia de produção pela Universidade Metodista de Piracicaba - UNIMEP, Engenheiro de Produção em Controle e Automação pela Universidade Tecnológica Federal do Paraná - Campus Ponta Grossa.

\section{APARECIDO DOS REIS COUTINHO}

Graduação: Licenciatura Plena em Física (UNESP-Universidade Estadual Paulista Júlio de Mesquita Filho, 1981); Mestrado: Ciências - Energia Nuclear na Agricultura (USP-Universidade de São Paulo, 1984); Doutorado: Ciências (UNICAMP-Universidade Estadual de Campinas, 1992); Pós doutorado: Física de Plasmas (ITA-Instituto Tecnológico da Aeronáutica, 1997). Docente do PPGEP-Programa de Pós Graduação em Engenharia de Produção da UNINOVE (Universidade Nove de Julho, São Paulo). Áreas de atuação: Inovação Tecnológica, Sustentabilidade: Ciclo de Vida de Produtos e Processos, Energia, Meio Ambiente, Produção Limpa. Desenvolvimento de projetos de P\&D em parceria com indústrias voltados à inovação tecnológica; sustentabilidade; materiais metálicos e não metálicos; materiais carbonosos e compósitos. $\mathrm{H}$-index=13. 


\section{AGRADECIMENTOS}

Primeiramente a Deus, pelos caminhos abertos.

A minha família, que me instruiu e deu suporte necessário durante todas as etapas da minha vida. Aos meus pais João Luiz Kovaleski e Nádia Kovaleski, minhas irmãs Fanny Kovaleski, Anais Kovaleski e Gabriela Kovaleski, responsáveis pela pessoa que sou hoje.

A meu orientador Prof. Dr. Aparecido dos Reis Coutinho, pelo modelo de exemplo, o qual me inspirou a ter força de vontade e atingir este objetivo. Pela compreensão e conduta incentivadora, responsáveis pelo orgulho e honra que sentem seus orientados.

A todos os colegas de laboratório, pela amizade, apoio e atenção. Em especial aos amigos Jean Azarias, Everton Dias e Élcio Martens.

A UNIMEP e os professores do PPGEP, pela abertura das portas e pela oportunidade concedida.

Aos colegas de trabalho, pelo companheirismo diário.

A Coordenação de Aperfeiçoamento de Pessoal de Nível Superior (CAPES) pelo apoio parcial. 


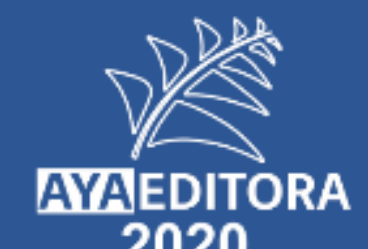
2020 